\title{
Petrology of the Parental Melts and Mantle Sources of Siberian Trap Magmatism
}

\author{
A. V. Sobolev ${ }^{a, b}$, N. A. Krivolutskaya ${ }^{a}$, and D. V. Kuzmin ${ }^{b, c}$ \\ ${ }^{a}$ Vernadsky Institute of Geochemistry and Analytical Chemistry, Russian Academy of Sciences, \\ ul. Kosygina 19, Moscow, 119991 Russia \\ e-mail: sobolev@geokhi.ru \\ ${ }^{b}$ Max-Planck Institute for Chemistry, PO Box 3060, 55020 Mainz, Germany \\ ${ }^{c}$ Sobolev Institute of Geology and Mineralogy, Siberian Branch, Russian Academy of Sciences, \\ pr. akademika Koptyuga 3, Novosibirsk, 630090 Russia \\ Received December 2, 2008
}

\begin{abstract}
Based on the investigation of olivine phenocrysts and melt and spinel inclusions in them from the picrites of the Gudchikhinsky Formation and olivine phenocrysts and the whole-rock geochemistry from the Tuklonsky and Nadezhdinsky formations of the Noril'sk region, the compositions and conditions of formation and evolution of the parental melts and mantle sources of Siberian trap magmatism were evaluated. Olivine phenocrysts from the samples studied are enriched in $\mathrm{Ni}$ and depleted in Mn compared with olivines equilibrated with the products of peridotite melting, which suggests a considerable role of a nonperidotitic component (olivine-free pyroxenite) in their mantle source. The onset of Siberian trap magmatism (Gudchikhinsky Formation) was related to the melting of pyroxenite produced by the interaction of ancient recycled oceanic crust with mantle peridotite. During the subsequent evolution of the magmatic system (development of the Tuklonsky and Nadezhdinsky formations), the fraction of the pyroxenite component in the source region decreased rapidly (to 40 and $60 \%$, respectively) owing to the entrainment of peridotite material into the melting zone. The formation of magmas was significantly affected by the contamination by continental crustal material. The primitive magmas of the Gudchikhinsky Formation crystallized under near-surface conditions at temperatures of 1250 $1170^{\circ} \mathrm{C}$ and oxygen fugacities $2.5-3.0$ orders of magnitude below the Ni-NiO buffer. Simultaneously, the magmas were contaminated by continental silicic rocks and evaporites. The parental magmas of the Gudchikhinsky rocks corresponded to tholeiitic picrites with 11-14 wt \% MgO. They were strongly undersaturated in sulfur, contained less than $0.25 \mathrm{wt} \%$ water and carbon dioxide, and were chemically similar to the Hawaiian tholeiites. They were produced by melting of a pyroxenite source at depths of $130-180 \mathrm{~km}$ in a mantle plume with a potential temperature of $1500-1580^{\circ} \mathrm{C}$. The presence of low melting temperature pyroxenite material in the source of Siberian trap magmas promoted the formation of considerable volumes of melt under the thick continental lithosphere, which could trigger its catastrophic collapse. The contribution of pyroxenite-derived melt to the magmas of the Siberian trap province was no less than 40-50\%. This component, whose solid residue was free of sulfides and olivine, played a key role in the origin of high contents of $\mathrm{Ni}, \mathrm{Cu}$, and Pt-group elements and low sulfur contents in the parental trap magmas and prevented the early dispersion of these elements at the expense of sulfide melt fractionation. The high contents of $\mathrm{Cl}$ in the magmas resulted in considerable $\mathrm{HCl}$ emission into the atmosphere and could be responsible for the mass extinction at the Paleozoic-Mesozoic boundary.
\end{abstract}

DOI: $10.1134 /$ S0869591109030047

\section{INTRODUCTION}

Large igneous provinces (LIP) are short-term (usually, a few million years) occurrences of simultaneous magmatic activity over tremendous areas of continents and oceans (Campbell and Griffiths, 1992). Among typical LIP are continental flood basalt provinces (e.g., Siberian and Deccan traps) and oceanic plateaus (e.g., Ontong-Java).

A number of often incompatible hypotheses have been proposed to explain the formation of LIP related to mantle magmatism. Two hypotheses are most widely accepted by researchers. The first is the model of thermal mantle plumes, whose heads produce LIP through the extensive decompression melting of mantle peridot- ites owing to high potential temperatures (White and McKenzie, 1988; Campbell and Griffiths, 1992; Dobretsov et al., 2008). The second hypothesis claims to explain the formation of continental LIP without a significant temperature anomaly in the convecting mantle assuming delamination and descent of lithospheric block with the subsequent space filling with hot convecting mantle material undergoing high degrees of decompression melting (e.g., Elkins-Tanton, 2005). The main shortcoming of these concepts is the absence of rigorous estimates for the conditions of formation of parental magmas and compositions of their mantle sources. The problem is especially difficult for continental flood basalt provinces, including the Siberian 
traps. This is related to the fact that the occurrences of flood basalt magmatism accessible for observation underwent considerable differentiation in the crust, and their composition was modified by mineral fractionation and crustal contamination (Sobolev, 1936). In such cases, the composition of parental magmas can be reconstructed using a combination of new methods based on the detailed analysis of olivine phenocrysts (Sobolev et al., 2005, 2007, 2008) and fragments of the magmatic system embedded in them (Roedder, 1984; Sobolev, 1996).

The Siberian trap province is of special importance among LIP. This is related, first, to its tremendous size, which makes it the largest continental basaltic LIP of Phanerozoic age (Masaitis, 1983; Reichow et al., 2005). Second, the formation of the province (within the accuracy of numerous datings) coincided with the most significant mass extinctions in the Earth's history at $251 \mathrm{Ma}$ at the Paleozoic-Mesozoic boundary; therefore, it is considered as a possible reason for this event (Campbell et al., 1992; Kamo et al., 2003; White and Saunders, 2005). Third, the province comprises the world's largest platinum-copper-nickel sulfide deposits (Dodin et al., 1971; Dyuzhikov et al., 1988; Naldrett et al., 1992). These unique features of Siberian trap basalts have not yet been explained within a single consistent model of their formation.

In this paper, we propose a model combining the plume hypothesis with the concept of delamination of subcontinental lithosphere, which is based on the idea of crustal recycling, i.e., re-entrainment of the ancient subducted oceanic crust into the melting zone (Hofmann and White, 1982). This model explains the considerable volumes of magmas formed deep beneath the continental lithosphere; the high concentrations of nickel, copper, and platinum-group elements and low contents of sulfur in the parental melts; and rapid changes in the composition of the mantle source during the evolution of flood basalt magmatism.

\section{OBJECTS}

\section{Short Description of Regional Geology}

The Siberian trap province includes several zones differing in the structure and thickness of lava and tuff sequences (Masaitis, 1983; Zolotukhin et al., 1986). Of special interest is the Noril'sk region (Fig. 1), which comprises a thick $(3.7 \mathrm{~km})$ volcanic sequence containing, in addition to widespread tholeiitic basalts, subalkaline and picritic rock varieties (Fedorenko et al., 1996). Its conspicuous feature is the presence of unique $\mathrm{Pt}-\mathrm{Cu}-\mathrm{Ni}$ mineralization in ultrabasic-basic intrusive complexes (Dodin et al., 1971; Dyuzhikov et al., 1988; Naldrett et al., 1992).

The main first-order fold structures of the regions (Fig. 1) are the Khantai-Rybinsky and Dudinsky arches composed of terrigenous sedimentary sequences of the Early and Middle Paleozoic, the Tunguska syneclise, and the Noril'sk-Kharaelakhsky depression, where coal-bearing rocks of the Tunguska Formation $\left(\mathrm{C}_{2}-\mathrm{P}_{1}\right)$ and numerous basalt flows $\left(\mathrm{P}_{2}-\mathrm{T}_{1}\right)$ are exposed. The depression includes the Noril'sk, Kharaelakhsky, and Ikonsky troughs (Dyuzhikov et al., 1988).

The volcanic sequence was subdivided into 11 formations on the basis of the petrographic and chemical compositions of volcanics and proportions of lavas and tuffs: Ivakinsky, Syverminsky, Gudchikhinsky, Khakanchansky, Tuklonsky, Nadezhdinsky, Morongovsky, Mokulaevsky, Kharaelakhsky, Kumginsky, and Samoedsky formations; subformations and members were distinguished in some of the formations (Dodin et al., 1971; Ryabov et al., 2000). The lower three formations occur only in the Noril'sk region, whereas the upper formations (starting from Morongovsky) were traced along strike over hundreds of kilometers to the east. Intermediate position is characteristic of the Khakachansky, Tuklonsky, and Nadezhdinsky formations, which occur outside the Noril'sk region and pinch out toward the Putorana Plateau.

\section{Sampling Sites}

The section of the tuff-lava sequence was studied by us mainly in the eastern part of the region, where nine of the 11 formations were detected (Fig. 2). Primary attention was given to highly magnesian extrusive rocks, which occur in the Gudchikhinsky $\left(\mathrm{Gd}_{2}\right)$, Tuklonsky (Tk), and Nadezhdinsky $\left(\mathrm{Nd}_{1}\right)$ formations.

The picritic basalts of the Gudchikhinsky Formation were investigated in several sections in different parts of the region. Three key sections were selected: in the western part of the Kharaelakhsky Trough, in the eastern slope of the Khantai-Rybinsky arch, and in the western slope of the Tunguska syneclise. This allowed us to trace the evolution of the structure and composition of the Gudchikhinsky picrites from west to east.

The thickest section of the Gudchikhinsky Formation was investigated in borehole $\mathrm{KhS}-51$ in the western part of the Kharaelakhsky Trough. The incomplete thickness of the formation (its upper part was eroded) is $460 \mathrm{~m}$. The lower part of the section is composed of porphyritic and aphyric basalts with an average $\mathrm{MgO}$ content of $6 \mathrm{wt} \%$, and the upper part $(111 \mathrm{~m})$ is made up of 17 flows of picritic basalts containing up to $24 \mathrm{wt} \%$ $\mathrm{MgO}$. The flows are of only moderate thicknesses (4-6 $\mathrm{m}$ on average), and their upper portions (0.5$1.3 \mathrm{~m})$ are composed of amygdaloidal varieties, which facilitated the distinguishing of flows in the section. The rocks are extensively altered, and olivine is almost completely replaced by serpentine or bowlingite. Fresh samples of picritic basalts were collected in the central part of the thickest and, consequently, least altered flow penetrated by the borehole at depths of 118-140 m. One of the samples (KhS-51/130) was studied in detail. The thickness of the Gudchikhinsky Formation 


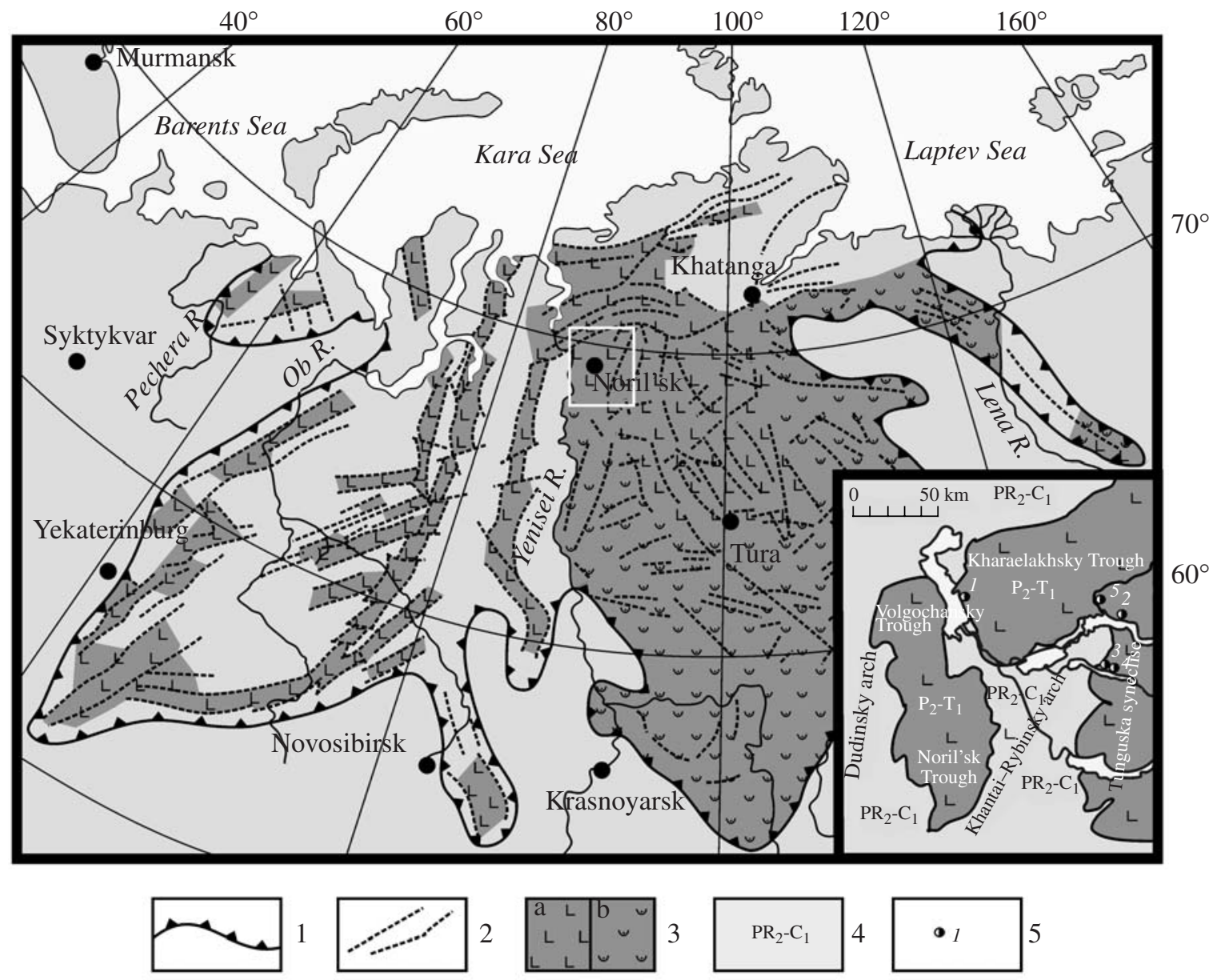

Fig. 1. Sketch map showing the distribution of tuff-lava rocks in the Siberian trap province and position of the Noril'sk region in its structure. Compiled after the data of Masaitis (1983) and Geological Map... (1991). (1) Boundary of the Siberian trap province; (2) faults; (3) rocks of the trap association: (a) basalts and (b) tuffs; (4) terrigenous sedimentary rocks of Paleoproterozoic-Early Carboniferous age; (5) sampling sites: 1, KhS-51/130; 2, 4270/13; 3, SU-50 (Gudchikhinsky Formation); 4, SU-33 (Tuklonsky Formation); and 5, 530/12 (Nadezhdinsky Formation).

decreases to a few tens of meters at the eastern side of the trough.

The structure and composition of the rocks of the formation change dramatically in the eastern slope of the Khantai-Rybinsky arch. Its thickness is only $22 \mathrm{~m}$, and the rocks of the lower subformation (basalt porphyries with normal $\mathrm{Mg}$ contents) are completely missing in the section. The formation is represented there by two picritic basalt flows with $\mathrm{MgO}$ contents of 1216 wt $\%$. It should be noted that the character of magmatism changes in this region: numerous central-type volcanoes appear there; they are a few tens of meters high and composed of thin $(10-15 \mathrm{~cm})$ beds of lava and ash materials. Thus, this rigid anticline structure is dominated by vertical fracture channels, which promoted faster magma ascent to the surface compared with the adjacent trough (which may be responsible for the less extensive crustal contamination of melts; sample 4270/13, see below).
The third section of the Gudchikhinsky Formation considered here is situated at the western part of the Tunguska syneclise. It includes a single picritic basalt flow, $8 \mathrm{~m}$ thick (sample SU-50).

The Tuklonsky and Nadezhdinsky formations contain very minor amounts of high-magnesium rocks. They were documented only in layered flows (Fig. 1). Picritic basalts were found in the Tuklonsky Formation at Sunduk Mountain (southern coast of Lake Glubokoe; Lightfoot et al., 1993) and in the Nadezhdinsky Formation among the rocks of the Mikchangdinsky cover (Krivolutskaya et al., 2005) in the eastern slope of the Khantai-Rybinsky arch. These rocks are represented by samples SU-50 (Tk) and 530/12 $\left(\mathrm{Nd}_{1}\right)$.

\section{Petrography}

The picritic basalts of the Gudchikhinsky Formation are macroscopically distinctly different from other lava varieties, including the high-magnesium rocks of the 

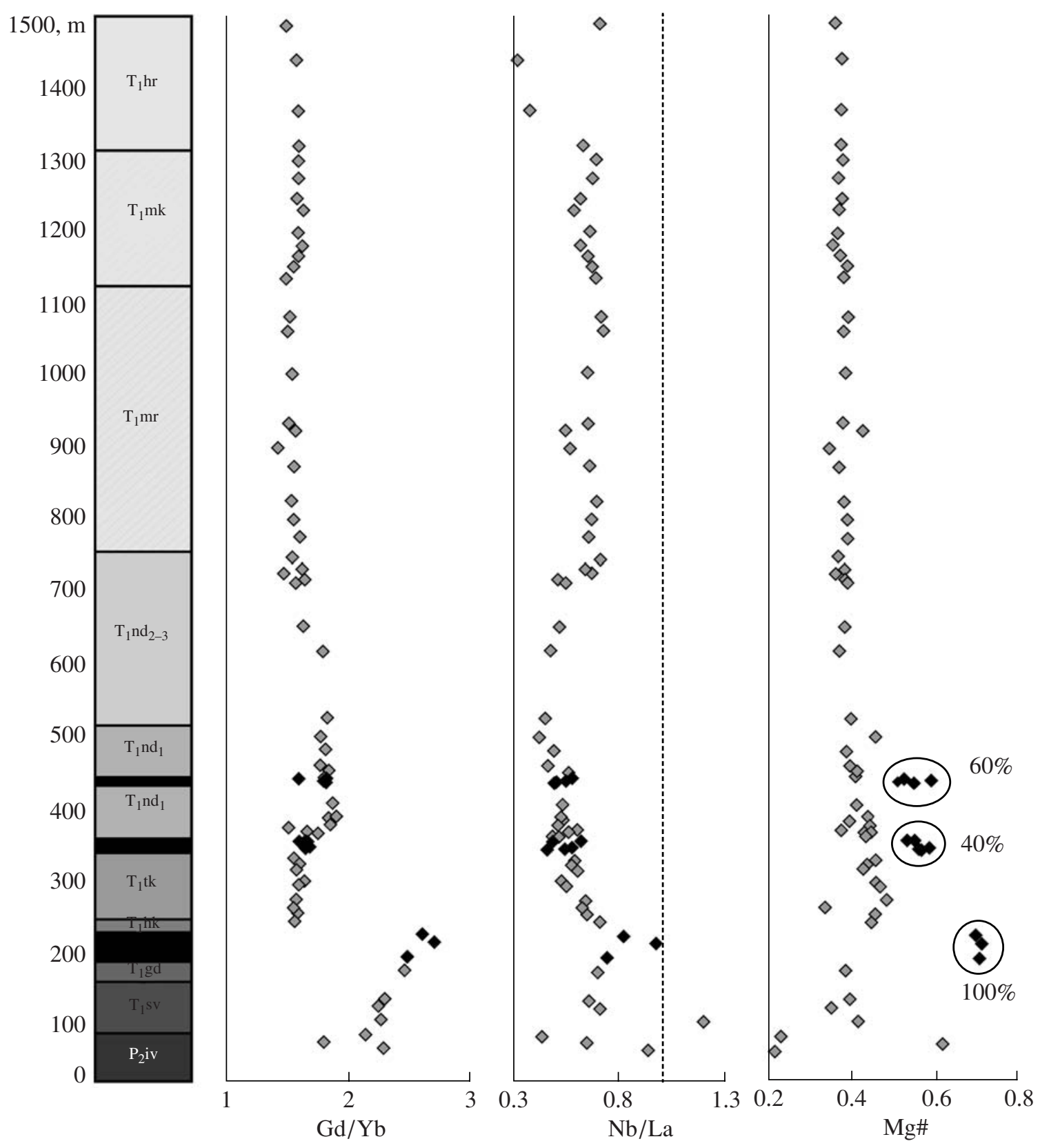

Fig. 2. Generalized section of volcanic rocks of the trap association for the eastern part of the Noril'sk region (basin of the Mikchangda River).

Formations: iv, Ivakinsky; sv, Syverminsky; gd, Gudchikhinsky; hk, Khakanchansky; tk, Tuklonsky; nd ${ }_{1}$, lower subformation of the Nadezhdinsky Formation; $\mathrm{nd}_{2-3}$, undifferentiated middle and upper subformations of the Nadezhdinsky Formation; mr, Morongovsky; mk, Mokulaevsky; and hr, Haraelakhsky. Horizons of high-magnesium rocks are shown in black. The encircled groups of rocks are the picrites and picritic basalts of the Gudchikhinsky ( $\left.T_{1} g d\right)$, Nadezhdinsky $\left(T_{1}\right.$ nd), and Tuklonsky ( $T_{1}$ tk) formations with the contribution (in \%) of the pyroxenite component in the melt calculated from the composition of magnesian olivine (Sobolev et al., 2007, 2008). The diagrams show variations in Mg\# and characteristic trace element ratios in the rocks along the section (black diamonds are picritic basalts, and gray diamonds are tholeiitic and subalkaline basalts). The dashed line corresponds to $\mathrm{Nb} / \mathrm{La}=1$.

Tuklonsky and Nadezhdinsky formations. They are dark gray (sometimes with a violet shade) medium- to coarse-grained massive rocks consisting of olivine (15$50 \mathrm{vol} \%)$, plagioclase (20-50\%), pyroxene (10-30\%), chrome spinel, and secondary minerals. Their struc- tural, textural, and mineral characteristics show minor variations.

The most magnesian picrites from the western part of the Kharaelakhsky Plateau (sample KhS-51/130) have a weakly manifested porphyritic structure and a 
hypidiomorphic texture. Their compositions are dominated by olivine (up to 50\%), whose large euhedral prismatic crystals $(2-3 \mathrm{~mm})$ appear as hexagonal or rectangular grains in thin sections. Small (up to $1 \mathrm{~mm}$ ) oval or rounded grains of this mineral often occur within elongated (up to $3 \mathrm{~mm}$ ) tabular crystals of plagioclase $(25 \%)$ forming a poikilitic texture. Clinopyroxene (13\%) also forms elongated (up to $1 \mathrm{~mm}$ ) grains, and orthopyroxene occurs in minor amounts (up to $3-4 \%$ ). The rock also contains chrome spinel, titanomagnetite, and serpentine-group minerals. Picritic basalts from the eastern slope of the Khantai-Rybninsky arch (sample 4270/13) have a finer grained hypidiomorphic texture. Olivine (about 20\%) usually occurs as small euhedral grains of uniform size $(0.5 \mathrm{~mm}$ on average) randomly distributed in the rock and is almost unaffected by secondary alteration. Plagioclase (about $50 \%)$ occurs as large laths $(5 \times 2 \mathrm{~mm})$, and pyroxene (about 30\%) forms smaller irregular grains. Typical picritic basalts from the western part of the Tunguska syneclise (sample SU-50) are very similar in mineral composition, texture, and structure to the rock variety described above, but they are better crystallized. Strongly altered subhedral olivine grains averages $1-2 \mathrm{~mm}$ in size (up to $15 \%$ ), and $60-70 \%$ of the grains are replaced by bowlingite or serpentine.

The picritic basalts of the Tuklonsky and Nadezhdinsky formations occur as 5-80-cm-thick interbeds among high-magnesium tholeiitic basalts (8-9 wt \% $\mathrm{MgO}$ ) and are similar to each other both in composition and textural features. In particular, they show a weak porphyritic structure and a doleritic texture of the groundmass, which contains radial aggregates of plagioclase and/or pyroxene. The sample of picritic basalt from the Tuklonsky Formation (SU-33) contains almost completely altered olivine grains (15\%), sheaflike intergrowths of plagioclase crystals up to $2 \mathrm{~mm}$ in size (30\%), and anhedral clinopyroxene grains (55\%).

Similar rocks from the Nadezhdinsky Formation (sample 530/12) contain up to 30 vol \% of small (1-2 mm) porphyritic olivine grains. They are uniformly distributed in the groundmass with a doleritic or radial texture composed of small $(0.5 \mathrm{~mm})$ plagioclase laths $(40 \%)$ and isometric pyroxene grains $(30 \%)$ of the same size.

\section{METHODS}

\section{Analytical Techniques}

Three microanalytical techniques were used to investigate the composition of minerals and melt inclusions: electron probe microanalysis, inductively coupled plasma mass spectrometry with laser ablation, and secondary ion mass spectrometry. Rock compositions were determined by X-ray fluorescence and inductively coupled plasma mass spectrometry.

The contents of major elements in rocks were measured by X-ray fluorescence (XRF) analysis using a
PANalytical AXIOS Advanced spectrometer at the Vernadsky Institute of Geochemistry and Analytical Chemistry of the Russian Academy of Sciences (analysts I.A. Roshchina and T.V. Romashova). An Rh anode X-ray tube (up to $4 \mathrm{~kW}$ ) was used for excitation. The relative errors (two standard deviations) for the concentration ranges observed in our samples were estimated from the reproducibility of standard analysis as $1.2 \%$ for $\mathrm{SiO}_{2} ; 3.5 \%$ for $\mathrm{Al}_{2} \mathrm{O}_{3} ; 6.2 \%$ for $\mathrm{FeO} ; 8 \%$ for $\mathrm{Na}_{2} \mathrm{O}, \mathrm{MgO}, \mathrm{P}_{2} \mathrm{O}_{5}, \mathrm{~K}_{2} \mathrm{O}, \mathrm{CaO}$, and $\mathrm{TiO}_{2} ; 14 \%$ for $\mathrm{Cr}_{2} \mathrm{O}_{3}$; and $17 \%$ for $\mathrm{MnO}$.

Bulk rock trace element contents were obtained by inductively coupled plasma mass spectrometry (ICP $M S$ ) at the Institute of Mineralogy and Geochemistry of Rare Elements (analyst D.Z. Zhuravlev) using an ELAN 6100 DRC spectrometer (Software Kit, May 2000, PerkinElmer SCIEX) operating in a standard mode. The sensitivity of the instrument was calibrated over the entire mass scale using standard solutions containing all of the elements analyzed in the samples. The quality of analysis and the sensitivity drift of the instrument were controlled by alternating sample and reference material (BCR-2 basalt; GeoRem database, http://georem.mpch-mainz.gwdg.de/) measurements. The detection limit (DL) ranged from 1-5 ppb for heavy and medium-mass elements (U, Th, REE, etc.) to 20-50 ppb for light elements (Be and others). The accuracy of analysis was 3-10\% relative for element concentrations higher than 20-50 DL.

Electron probe microanalysis (EPMA) was employed to measure major and minor element contents higher than $100 \mathrm{ppm}$ in olivine, spinel, and melt inclusion glasses. The analyses were obtained using a Jeol JXA 8200 SuperProbe electron microprobe at the Max-Planck Institute of Chemistry (Mainz, Germany). The major elements of glasses and spinels were analyzed at accelerating voltages of 15 and $20 \mathrm{kV}$, respectively, and a beam current of 20-30 nA using natural standard samples: basaltic glass USMN111240/52 (VG2) and chrome spinel USMN117075 (Jarosevich et al., 1980) with typical errors of less than $2 \%$ relative. The composition of olivine and some elements in inclusions were analyzed using a special procedure providing an accuracy of 20-30 ppm (two standard deviations) for $\mathrm{Ni}, \mathrm{Ca}, \mathrm{Mn}, \mathrm{Al}, \mathrm{Ti}, \mathrm{Cr}$, and $\mathrm{Co}$ and $0.02 \mathrm{~mol} \%$ for the forsterite component of olivine (Sobolev et al., 2007).

Laser ablation-inductively coupled plasma mass spectrometry (LA-ICP MS) was used to determine trace element contents in melt inclusion glasses and olivine. Analyses were carried out on an ELEMENT-2 (Thermo Scientific, England) mass spectrometer coupled to a UP-213 (New Wave Research, England) solidstate laser at the Max-Planck Institute of Chemistry (Mainz, Germany). Basaltic glasses KL-2G and NIST 612 (Jochum et al., 2000 and GeoRem database, http://georem.mpch-mainz.gwdg.de/) were used as standards. The analyses were normalized to Ca content. The laser beam diameter was usually $60-80 \mu \mathrm{m}$, and 
the ablation time was $60-80 \mathrm{~s}$. The uncertainty of concentrations was estimated from the reproducibility of standard analysis as no higher than 5\% relative (two standard deviations) for contents higher than $1 \mathrm{ppm}$ and $10 \%$ relative for contents of $\sim 0.1 \mathrm{ppm}$.

Secondary ion mass spectrometry (SIMS) was used to analyze $\mathrm{H}_{2} \mathrm{O}, \mathrm{Li}$, and $\mathrm{B}$ in melt inclusion glasses. The analyses were obtained using a Cameca Ims3f ion microprobe (France) at the Max-Planck Institute of Chemistry (Mainz, Germany) by the method described by Sobolev (1996). The analytical uncertainties were typically no higher than $10 \%$ relative. The detection limit for $\mathrm{H}_{2} \mathrm{O}$ was estimated from the signal of ${ }^{1} \mathrm{H}$ in the host olivine as $0.02 \mathrm{wt} \%$.

\section{Experimental Investigations}

Melt inclusions were studied using a low-inertia visually controlled heating stage with a purified $\mathrm{He}$ atmosphere (Sobolev and Slutskii, 1984) by the method of Sobolev and Danyushevsky (1994). Experimental temperature was measured by a Pt90Rh10 thermocouple and checked in every experiment against the melting point of high-purity gold. In order to minimize $\mathrm{H}_{2} \mathrm{O}$ loss from inclusions, the total exposure to temperatures of higher than $1000^{\circ} \mathrm{C}$ was no longer than $15 \mathrm{~min}$.

In addition to experiments under visual control, quench experiments were carried out using a controlled-atmosphere vertical furnace at the Petrology and Geochemistry Department of J.-W.-Goethe University of Frankfurt am Maine, Germany. The experiments were carried out with an $\mathrm{H}_{2} / \mathrm{CO}_{2}$ gas mixture at a temperature of $1250^{\circ} \mathrm{C}$ and oxygen fugacity corresponding to the quartz-fayalite-magnetite (QFM) buffer. Selected olivine crystals were loaded into open platinum capsules and placed in a platinum container directly into the hot zone of the furnace. After a 20-min exposure, the samples were quenched by automatically dropping the platinum container into the cold zone.

\section{RESULTS}

\section{Composition of Rocks}

The Noril'sk traps are dominated by low-magnesium $(\mathrm{MgO}<7$ wt \%) tholeiitic basalts and contain minor olivine basalts and picrites. Alkaline and subalkaline varieties are rare and occur mainly in the lower formations, Ivakinsky and Syverminsky. The composition of lavas changes systematically from bottom to top (Fig. 2), which is in agreement with the data of previous authors (Lightfoot et al., 1993; Wooden et al., 1993). The lower formations are significantly depleted in heavy REE and, correspondingly, show high $\mathrm{Gd} / \mathrm{Yb}$ ratios, which suggests the presence of garnet in their source (Lightfoot et al., 1993; Wooden et al., 1993; Sharma, 1997). This parameter decreases considerably in the rocks directly overlying the Gudchikhinsky Formation, and most of the lavas of the sequence exhibit no evidence for the retention of garnet in the source. The $\mathrm{Nb} / \mathrm{La}$ ratio is significantly variable within the section. Similar to $\mathrm{Ta} / \mathrm{La}$, this ratio reflects the degree of magma contamination by continental crust (Lightfoot et al., 1993). The $\mathrm{Nb} / \mathrm{La}<1$ value for an undepleted composition implies a negative $\mathrm{Nb}(\mathrm{Ta})$ anomaly, which is compelling evidence for the contribution of continental crust (Rudnick, 2002). Figure 2 demonstrates that most of the Noril'sk trap rocks are contaminated by continental crust. The degree of contamination ranges from the minimum values in the rocks of the Gudchikhinsky Formation to the maximum values in the Nadezhdinsky basalts (Wooden et al., 1993).

In the Noril'sk region, magnesian rocks are known only in lower formations, Gudchikhinsky, Tuklonsky, and Nadezhdinsky (Fig. 2). Their compositions are shown in Fig. 3. The main difference of the Gudchikhinsky rocks from the overlying Tuklonsky and Nadezhdinsky basalts is the depletion of heavy REE and, correspondingly, high $\mathrm{Gd} / \mathrm{Yb}$ ratios (Fig. 2). The compositions of two samples from the Gudchikhinsky Formation (4270/13 and SU-50) are similar to each other in most elements but are significantly different from the third sample, KhS-51/130 (Fig. 3a). The latter is much stronger enriched in olivine, and, therefore, its incompatible element patterns are shifted to lower concentrations. It also bears distinct signs of crustal contamination: enrichment in $\mathrm{Th}, \mathrm{U}$, and $\mathrm{Pb}$ and depletion in $\mathrm{Nb}, \mathrm{Ta}$, and $\mathrm{Ti}$. These features are even more pronounced in the magnesian rocks of the Tuklonsky (sample SU-33) and especially Nadezhdinsky formations (sample 530/12) (Fig. 3b). The trace element patterns of these rocks closely resemble the composition of the continental crust.

The magnesian rocks described here can be considered as the least differentiated primitive members of the main geochemical types of the Siberian trap basalts of the Noril'sk region (Table 1). The Gudchikhinsky picrites are primitive rocks for the moderately titaniferous basalts, which accounts for $\sim 8 \%$ of the lavas of the section (Fedorenko et al., 1996). With respect to combined geochemical characteristics, the Tuklonsky picrites correspond to the main low-titanium type of magmatism, accounting for more than $75 \mathrm{vol} \%$ of the Noril'sk section and are significantly different from other rocks of this suite only in low $\mathrm{Pb}$ isotope ratios, ${ }^{206} \mathrm{~Pb} /{ }^{204} \mathrm{~Pb}$ and ${ }^{208} \mathrm{~Pb} /{ }^{204} \mathrm{~Pb}$ (Wooden et al., 1993; Fedorenko et al., 1996). However, since crustal contaminant provided the main contribution to the content and isotopic composition of $\mathrm{Pb}$ in the Tuklonsky picrites (Fig. 3b), this difference should be attributed to different compositions of contaminants rather than the heterogeneity of primary magmas. The magnesian rocks of the Nadezhdinsky Formation are crystallization products of the most contaminated primitive magmas producing the rocks of this formation (Krivolutskaya et al., 2005; Reichow et al., 2005). 


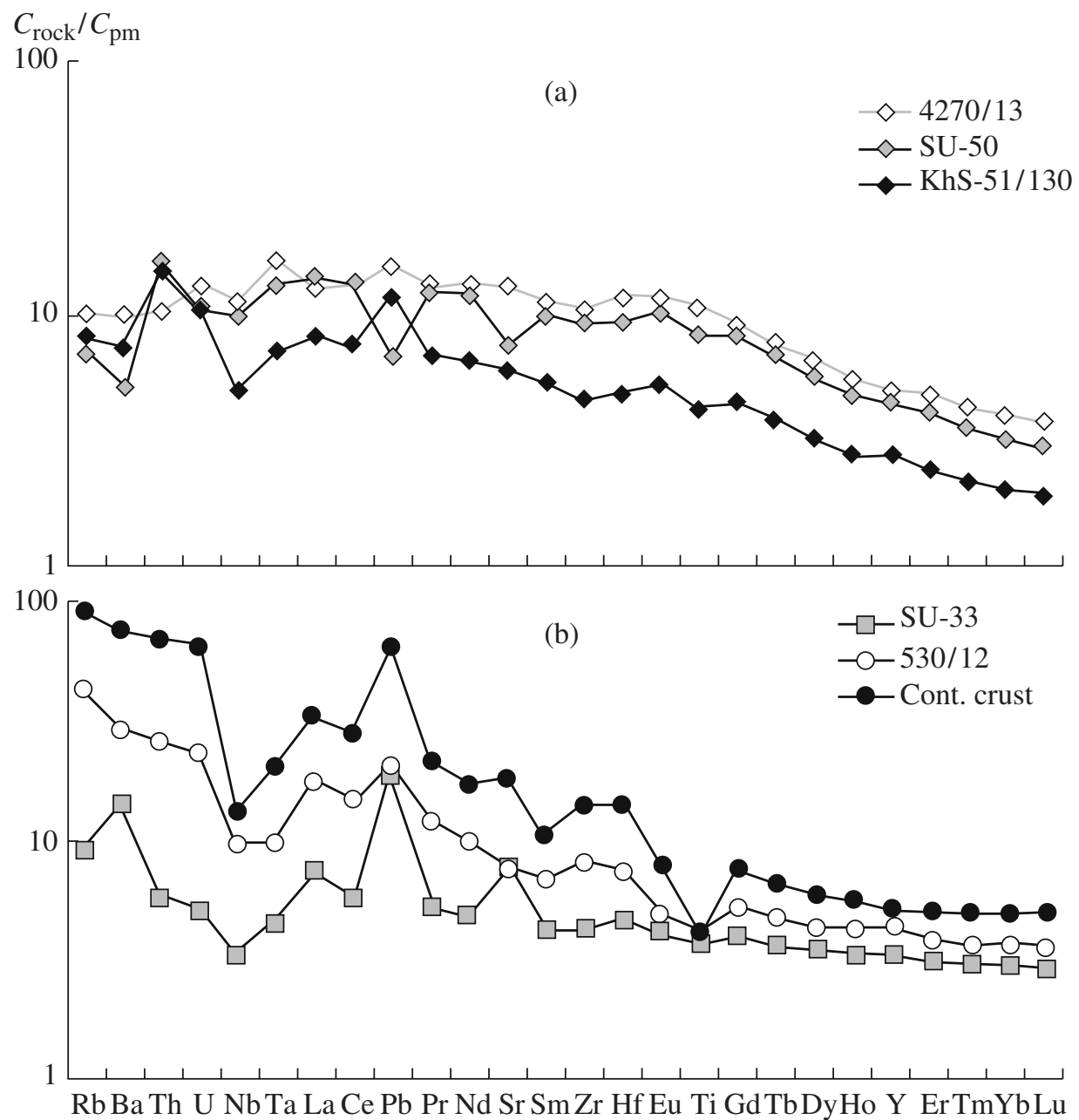

Fig. 3. Trace element patterns of (a) the high-magnesium volcanic rocks of the Gudchikhinsky Formation and (b) the rocks of the Tuklonsky (sample SU-33) and Nadezhdinsky (sample 530/12) formations. "Cont. crust" is the average compositions of the continental crust (Rudnick, 2002). $C_{\text {rock }} / C_{\mathrm{pm}}$ is element content in the rock normalized to the primitive mantle value (Hofmann, 1988).

\section{Composition of Spinel}

Spinel inclusions in olivine phenocrysts from the rocks of the Gudchikhinsky Formation (Table 2) correspond to a $\mathrm{Cr}$-rich variety, $\mathrm{Cr} /(\mathrm{Cr}+\mathrm{Al})=0.70 \pm 0.03$, with high $\mathrm{TiO}_{2}(1.6 \pm 0.4 \mathrm{wt} \%)$ and $\mathrm{V}_{2} \mathrm{O}_{3}$ contents $(0.5 \pm 0.1 \mathrm{wt} \%)$ and high $\mathrm{Fe}^{+2} / \mathrm{Fe}^{+3}(5.0 \pm 0.6)$. The composition of spinel is not correlated with that of host olivine, which varies within $\mathrm{Fo}_{84}-\mathrm{Fo}_{79}$. Noteworthy are the high $\mathrm{Fe}^{+2} / \mathrm{Fe}^{+3}$ ratio and significant contents of vanadium in the spinel, which indicates unusually low oxygen fugacity in the crystallization environment (Canil, 2002).

\section{Composition of Olivine}

Three groups of olivine phenocryst compositions are clearly distinguished (Table 3, Fig. 4). The first group comprises high-Ni and low-Mn olivines from the rocks of the Gudchikhinsky Formation, which practically have no analogues among the olivines of mantle magmas. The content of the forsterite component in the olivines of this group is up to $84 \%$. Magnesian olivines from the rocks of the Nadezhdinsky Formation contain less $\mathrm{Ni}$ and more $\mathrm{Mn}$, and the lowest Ni contents coupled with the highest $\mathrm{Mn}$ are characteristic of olivines from the rocks of the Tuklonsky Formation. In the latter two groups, the maximum content of the forsterite component is no higher than $80 \%$. A characteristic feature of olivine from the rocks of the Nadezhdinsky Formation is the steep trend of a decrease in $\mathrm{Ni}$ content with decreasing $\mathrm{MgO}$, which is not reflected in the $\mathrm{Mn} / \mathrm{Fe}$ ratio. This trend is readily explained by the segregation of sulfide melt from the parental magma of the Nadezhdinsky rocks; this process was considered by Naldrett et al. (1992) as a reason for the depletion of the Nadezhdinsky lavas in ore elements.

Sobolev et al. $(2005,2007)$ showed that Ni excess and $\mathrm{Mn}$ deficit in olivine composition compared with the level of equilibrium with mantle peridotites are indicative of the presence of melting products from oli- 
Table 1. Composition of magnesian rocks from the Noril'sk region of the Siberian trap province

\begin{tabular}{|c|c|c|c|c|c|}
\hline $\begin{array}{c}\text { Com- } \\
\text { ponent }\end{array}$ & $\begin{array}{c}\mathrm{Gd} \\
4270 / 13 *\end{array}$ & $\begin{array}{c}\mathrm{Gd} \\
\mathrm{SU}-50\end{array}$ & \begin{tabular}{|c|}
$\mathrm{Gd}$ \\
$\mathrm{KhS}-51 / 130$
\end{tabular} & $\begin{array}{c}\text { Tk } \\
\text { SU-33 }\end{array}$ & $\begin{array}{c}\mathrm{Nd} \\
530 / 12\end{array}$ \\
\hline $\mathrm{SiO}_{2}$ & 47.33 & 44.40 & 44.47 & 43.75 & 48.12 \\
\hline $\mathrm{TiO}_{2}$ & 2.13 & 1.58 & 0.88 & 0.70 & 0.65 \\
\hline $\mathrm{Al}_{2} \mathrm{O}_{3}$ & 10.14 & 8.07 & 6.68 & 12.12 & 9.93 \\
\hline $\mathrm{Fe}_{2} \mathrm{O}_{3}$ & 13.22 & 12.94 & 13.35 & 12.34 & 12.82 \\
\hline $\mathrm{MnO}$ & 0.18 & 0.19 & 0.19 & 0.18 & 0.18 \\
\hline $\mathrm{MgO}$ & 13.14 & 18.85 & 22.97 & 15.27 & 17.28 \\
\hline $\mathrm{CaO}$ & 9.54 & 6.58 & 5.37 & 8.51 & 7.74 \\
\hline $\mathrm{Na}_{2} \mathrm{O}$ & 2.40 & 0.78 & 0.62 & 0.78 & 0.33 \\
\hline $\mathrm{K}_{2} \mathrm{O}$ & 0.26 & 0.10 & 0.07 & 0.23 & 0.65 \\
\hline $\mathrm{P}_{2} \mathrm{O}_{5}$ & 0.20 & 0.17 & 0.10 & 0.06 & 0.08 \\
\hline $\mathrm{Cr}_{2} \mathrm{O}_{3}$ & 0.10 & 0.15 & 0.18 & 0.09 & 0.18 \\
\hline LOI & 1.44 & 5.35 & 5.40 & 6.37 & 2.98 \\
\hline Total & 100.07 & 99.15 & 100.28 & 100.40 & 100.93 \\
\hline$\overline{\mathrm{Sc}}$ & 18.9 & 17.5 & 15.9 & 16.9 & 29.2 \\
\hline V & 260 & 202 & 148 & 179 & 194 \\
\hline $\mathrm{Co}$ & 66 & 83 & 101 & 79 & 87 \\
\hline $\mathrm{Ni}$ & 211 & 1057 & 1532 & 429 & 349 \\
\hline $\mathrm{Cu}$ & 66 & 67 & 50 & 79 & 20 \\
\hline $\mathrm{Zn}$ & 98 & 92 & 82 & 73 & 82 \\
\hline $\mathrm{Rb}$ & 5.3 & 3.8 & 4.4 & 4.9 & 23.1 \\
\hline $\mathrm{Sr}$ & 229 & 135 & 106 & 139 & 138 \\
\hline $\mathrm{Y}$ & 20 & 20 & 12 & 12 & 16 \\
\hline $\mathrm{Zr}$ & 99 & 88 & 44 & 40 & 77 \\
\hline $\mathrm{Nb}$ & 6.8 & 6.0 & 3.1 & 2.0 & 5.9 \\
\hline Cs & 2.28 & 1.59 & 0.39 & 4.16 & 3.33 \\
\hline $\mathrm{Ba}$ & 59 & 32 & 44 & 85 & 174 \\
\hline $\mathrm{La}$ & 7.7 & 8.3 & 5.0 & 4.5 & 10.8 \\
\hline $\mathrm{Ce}$ & 21 & 21 & 12 & 9 & 23 \\
\hline $\mathrm{Pr}$ & 3.09 & 2.94 & 1.65 & 1.23 & 2.79 \\
\hline $\mathrm{Nd}$ & 15 & 14 & 8 & 6 & 12 \\
\hline $\mathrm{Sm}$ & 4.2 & 3.8 & 2.0 & 1.6 & 2.6 \\
\hline $\mathrm{Eu}$ & 1.63 & 1.45 & 0.75 & 0.58 & 0.70 \\
\hline $\mathrm{Gd}$ & 4.54 & 4.12 & 2.25 & 1.93 & 2.60 \\
\hline $\mathrm{Tb}$ & 0.69 & 0.62 & 0.35 & 0.33 & 0.43 \\
\hline Dy & 4.00 & 3.49 & 2.00 & 2.13 & 2.61 \\
\hline Ho & 0.76 & 0.66 & 0.38 & 0.44 & 0.58 \\
\hline $\mathrm{Er}$ & 1.96 & 1.64 & 0.98 & 1.23 & 1.52 \\
\hline $\mathrm{Tm}$ & 0.26 & 0.22 & 0.13 & 0.18 & 0.22 \\
\hline $\mathrm{Yb}$ & 1.57 & 1.28 & 0.80 & 1.16 & 1.43 \\
\hline $\mathrm{Lu}$ & 0.23 & 0.18 & 0.12 & 0.17 & 0.21 \\
\hline Hf & 3.03 & 2.44 & 1.26 & 1.20 & 1.93 \\
\hline $\mathrm{Ta}$ & 0.57 & 0.45 & 0.25 & 0.16 & 0.34 \\
\hline $\mathrm{Pb}$ & 2.64 & 1.17 & 2.02 & 3.27 & 3.41 \\
\hline $\mathrm{Th}$ & 0.82 & 1.28 & 1.19 & 0.47 & 2.09 \\
\hline $\mathrm{U}$ & 0.27 & 0.21 & 0.21 & 0.10 & 0.47 \\
\hline
\end{tabular}

Note: Here and in Tables 2-6, oxides and total are in wt \%, and elements are in ppm. LOI is loss on ignition in wt \%. Formations: Gd, Gudchikhinsky; Tk, Tuklonsky; and Nd, Nadezhdinsky.

* Sample no.

vine-free pyroxenite formed by the reaction between recycled crust and peridotite. The $\mathrm{Mn} / \mathrm{Fe}$ and $\mathrm{Ni} /(\mathrm{Mg} / \mathrm{Fe})$ ratios of olivine were parameterized to determine the fraction of melt from a pyroxenite source in the bulk composition of magma (Sobolev et al., 2007, 2008). This parameter was estimated indepen- dently on the basis of $\mathrm{Mn} / \mathrm{Fe}$ and $\mathrm{Ni} /(\mathrm{Mg} / \mathrm{Fe})$ ratios for olivine phenocrysts from our samples (Fig. 5). Average values for the most magnesian olivines are shown by large symbols in Fig. 5. It is evident that the olivine phenocrysts from the Gudchikhinsky Formation indicate an almost pure olivine-free pyroxenite source for these magmas, which was previously noted by Sobolev et al. (2007). The compositions of magnesian olivines from the rocks of the Nadezhdinsky and Tuklonsky formations indicate a significantly lower contribution from a pyroxenite source. Sulfide melt fractionation in the magmas of the Nadezhdinsky Formation leads to significantly underestimated contributions of the pyroxenite component calculated from the $\mathrm{Ni} /(\mathrm{Mg} / \mathrm{Fe})$ ratio of olivine, but has almost no effect on the estimates based on the $\mathrm{Mn} / \mathrm{Fe}$ ratio (Fig. 5).

\section{Inclusions in Olivine}

Magmatic inclusions were investigated in olivine from samples KhS-51/130, 4270/13, and SU-50 of the Gudchikhinsky Formation. They are represented by crystallized melt, spinel, low-density fluid, and occasionally combinations of these phases in varying proportions. Most of the inclusions are not confined to fractures but are randomly distributed within the phenocryst volume. Such inclusions are interpreted as primary, i.e., trapped during phenocryst growth (Roedder, 1984).

Most of the melt inclusions have rounded or ellipsoidal shapes. Their typical size ranges from 20 to $80 \mu \mathrm{m}$ along the long axis. The inclusions are composed of clinopyroxene crystals, interstitial glass, lowdensity fluid phase (shrinkage voids), spinel crystals, and occasionally tiny droplets of sulfide melt (Figs. 6a, $6 c)$. During heating, the inclusions begin to melt at temperatures of $1050-1100^{\circ} \mathrm{C}$, and the last daughter pyroxene crystal disappears at $1150-1180^{\circ} \mathrm{C}$. Homogenization (complete dissolution of the fluid phase in the melt) occurs almost simultaneously in all inclusions of a series (Fig. 6d). According to the results of 15 experiments, the range of homogenization temperatures is $1180-1290^{\circ} \mathrm{C}$. In some of the homogenized inclusions, a well shaped spinel crystal was preserved after quenching (Fig. 6b); such crystals were interpreted as xenocrysts trapped with the melt.

In order to obtain statistically representative data on the composition of melt inclusions, 100-150 olivine grains from each of samples KhS-51/130, 4270/13, and SU-50 were annealed for $20 \mathrm{~min}$ at a temperature of $1250^{\circ} \mathrm{C}$ in the vertical furnace at oxygen fugacity corresponding to the QFM buffer and quenched (see the "Methods" section). The quenched crystals were sectioned, polished, and examined under a microscope. Homogeneous inclusions or inclusions with a shrinkage void (fluid vesicle) accounting for less than $0.1 \%$ of inclusion volume and more than $40 \mu \mathrm{m}$ in size were selected for analysis (Figs. 6b, 6d). 
Table 2. Representative compositions of spinel inclusions in olivine phenocrysts from the picrites of the Gudchikhinsky Formation

\begin{tabular}{|c|c|c|c|c|c|c|c|c|c|}
\hline Component & ol5-12-18* & ol5-12-20 & ol5-12-23 & ol5-13-1 & ol5-13-11 & ol5-13-13 & ol5-13-21 & ol5-15-1 & ol5-15-11 \\
\hline$\overline{\mathrm{SiO}_{2}}$ & 0.36 & 0.34 & 0.48 & 0.34 & 0.36 & 0.34 & 0.38 & 0.34 & 0.39 \\
\hline $\mathrm{TiO}_{2}$ & 1.70 & 1.54 & 1.20 & 1.36 & 1.52 & 1.52 & 0.93 & 1.44 & 2.87 \\
\hline $\mathrm{Al}_{2} \mathrm{O}_{3}$ & 14.4 & 13.4 & 13.3 & 13.2 & 13.5 & 12.3 & 10.4 & 13.2 & 13.2 \\
\hline $\mathrm{Cr}_{2} \mathrm{O}_{3}$ & 45.7 & 46.5 & 46.8 & 46.5 & 46.7 & 44.9 & 49.5 & 46.5 & 41.1 \\
\hline $\mathrm{V}_{2} \mathrm{O}_{3}$ & 0.33 & 0.39 & 0.45 & 0.49 & 0.41 & 0.39 & 0.44 & 0.45 & 0.71 \\
\hline $\mathrm{FeO}_{\text {tot }}$ & 27.4 & 28.5 & 27.7 & 29.0 & 27.4 & 32.8 & 28.6 & 29.3 & 31.3 \\
\hline $\mathrm{MnO}$ & 0.26 & 0.25 & 0.26 & 0.30 & 0.22 & 0.27 & 0.30 & 0.27 & 0.32 \\
\hline $\mathrm{MgO}$ & 8.41 & 7.43 & 7.08 & 6.60 & 8.09 & 5.98 & 6.63 & 6.86 & 6.98 \\
\hline $\mathrm{NiO}$ & 0.19 & 0.16 & 0.14 & 0.14 & 0.17 & 0.14 & 0.14 & 0.16 & 0.23 \\
\hline $\mathrm{ZnO}$ & 0.15 & 0.19 & 0.22 & 0.21 & 0.18 & 0.21 & 0.23 & 0.18 & 0.24 \\
\hline Total 1 & 99.0 & 98.7 & 97.7 & 98.2 & 98.5 & 98.9 & 97.7 & 98.8 & 97.5 \\
\hline$\overline{\mathrm{FeO}}$ & 22.6 & 23.7 & 23.7 & 24.6 & 22.7 & 25.9 & 23.6 & 24.5 & 25.11 \\
\hline $\mathrm{Fe}_{2} \mathrm{O}_{3}$ & 5.3 & 5.3 & 4.4 & 4.9 & 5.2 & 7.7 & 5.6 & 5.4 & 6.9 \\
\hline Total 2 & 99.5 & 99.2 & 98.1 & 98.7 & 99.0 & 99.7 & 98.2 & 99.3 & 98.1 \\
\hline $\mathrm{Fe}^{+2 /+3} \mathrm{sp}$ & 4.8 & 5.0 & 6.1 & 5.6 & 4.9 & 3.7 & 4.7 & 5.1 & 4.0 \\
\hline $\mathrm{Fe}^{+2 /+3} \mathrm{~m}$ & 21.9 & 23.1 & 29.7 & 26.9 & 22.5 & 15.9 & 21.2 & 23.7 & 17.5 \\
\hline$\overline{F o}$ & 82.1 & 82.6 & 81.0 & 83.4 & 79.1 & 82.8 & 81.4 & 81.4 & 81.6 \\
\hline Component & ol5-15-18 & ol5-15-19 & ol5-16-7 & 6ol-2-4 & 6ol-2-6 & 6ol-2-7 & 6ol-3-2 & 6ol-3-7 & 6ol-3-10 \\
\hline$\overline{\mathrm{SiO}_{2}}$ & 0.42 & 0.34 & 0.36 & 0.37 & 0.36 & 0.34 & 0.34 & 0.33 & 0.36 \\
\hline $\mathrm{TiO}_{2}$ & 1.51 & 1.33 & 2.80 & 1.56 & 1.84 & 1.52 & 1.59 & 1.44 & 1.34 \\
\hline $\mathrm{Al}_{2} \mathrm{O}_{3}$ & 13.9 & 12.5 & 13.1 & 13.2 & 17.8 & 13.2 & 13.4 & 13.3 & 12.6 \\
\hline $\mathrm{Cr}_{2} \mathrm{O}_{3}$ & 46.2 & 48.3 & 43.1 & 45.4 & 40.8 & 45.7 & 44.9 & 45.6 & 46.2 \\
\hline $\mathrm{V}_{2} \mathrm{O}_{3}$ & 0.45 & 0.40 & 0.56 & 0.48 & 0.38 & 0.41 & 0.45 & 0.44 & 0.45 \\
\hline $\mathrm{FeO}_{\text {tot }}$ & 28.5 & 27.9 & 30.2 & 30.5 & 28.9 & 29.6 & 30.6 & 28.9 & 30.5 \\
\hline $\mathrm{MnO}$ & 0.25 & 0.24 & 0.29 & 0.27 & 0.25 & 0.27 & 0.26 & 0.27 & 0.28 \\
\hline $\mathrm{MgO}$ & 7.18 & 7.18 & 6.43 & 6.23 & 8.21 & 6.86 & 6.47 & 7.03 & 6.41 \\
\hline $\mathrm{NiO}$ & 0.14 & 0.13 & 0.18 & 0.16 & 0.21 & 0.13 & 0.16 & 0.15 & 0.14 \\
\hline $\mathrm{ZnO}$ & 0.19 & 0.19 & 0.23 & 0.22 & 0.19 & 0.19 & 0.20 & 0.20 & 0.23 \\
\hline Total 1 & 98.9 & 98.6 & 97.5 & 98.5 & 98.9 & 98.3 & 98.4 & 97.7 & 98.6 \\
\hline $\mathrm{FeO}$ & 24.3 & 23.8 & 25.9 & 25.5 & 23.5 & 24.4 & 25.2 & 23.9 & 25.0 \\
\hline $\mathrm{Fe}_{2} \mathrm{O}_{3}$ & 4.6 & 4.6 & 4.9 & 5.6 & 5.9 & 5.7 & 6.0 & 5.5 & 6.2 \\
\hline Total 2 & 99.3 & 99.0 & 97.9 & 99.0 & 99.5 & 98.9 & 99.0 & 98.3 & 99.2 \\
\hline $\mathrm{Fe}^{+2 /+3} \mathrm{sp}$ & 5.9 & 5.8 & 5.9 & 5.1 & 4.4 & 4.8 & 4.7 & 4.8 & 4.5 \\
\hline $\mathrm{Fe}^{+2 /+3} \mathrm{~m}$ & 28.4 & 27.9 & 28.9 & 23.6 & 19.8 & 21.7 & 21.0 & 22.0 & 20.1 \\
\hline$F o$ & 82.5 & 82.7 & 81.6 & 82.3 & 80.3 & 79.5 & 81.3 & 80.1 & 82.2 \\
\hline
\end{tabular}

Note: $\mathrm{FeO}$ and $\mathrm{Fe}_{2} \mathrm{O}_{3}$ in spinel were calculated assuming ideal stoichiometry; $\mathrm{FeO}_{\text {tot }}$ is total iron calculated as FeO. Total 1 and Total 2 are analytical totals calculated before and after the calculation of ferric and ferrous iron contents, respectively. Fe ${ }^{+2 /+3} \mathrm{sp}$ is the ferrous to ferric Fe ratio of spinel, and $\mathrm{Fe}^{+2 /+3}$ is the ferrous to ferric iron ratio in melt calculated using the model of Maurel and Maurel (1982). Here and in tables 3-6, Fo is the molar percentage of the forsterite component in the host olivine.

* Sample no.

\section{Crystallization Conditions and Melt Composition}

The compositions of 37 quenched melt inclusions and their host olivines from the samples of the Gudchikhinsky Formation are given in Table 4. Since the quenching temperature $\left(1250^{\circ} \mathrm{C}\right)$ of inclusions in the vertical furnace was in general different from the temperature of entrapment, the compositions of inclusions were additionally recalculated to equilibrium with the host olivine using the model of Ford et al. (1983). There is a significant linear correlation between the contents of $\mathrm{FeO}$ in the inclusions and host olivine, $\mathrm{FeO}_{\text {melt }}=$ $0.53 \mathrm{FeO}_{\mathrm{Ol}}-0.9(R=0.7$, Table 4$)$, which indicates the loss of Fe from the inclusions owing to the diffusion redistribution of $\mathrm{Fe}$ and $\mathrm{Mg}$ between the inclusions and host olivine during cooling (Sobolev and Danyushevsky, 1994). This effect can be accounted for on the basis of a significant correlation between $\mathrm{FeO}$ and $\mathrm{SiO}_{2}$ 


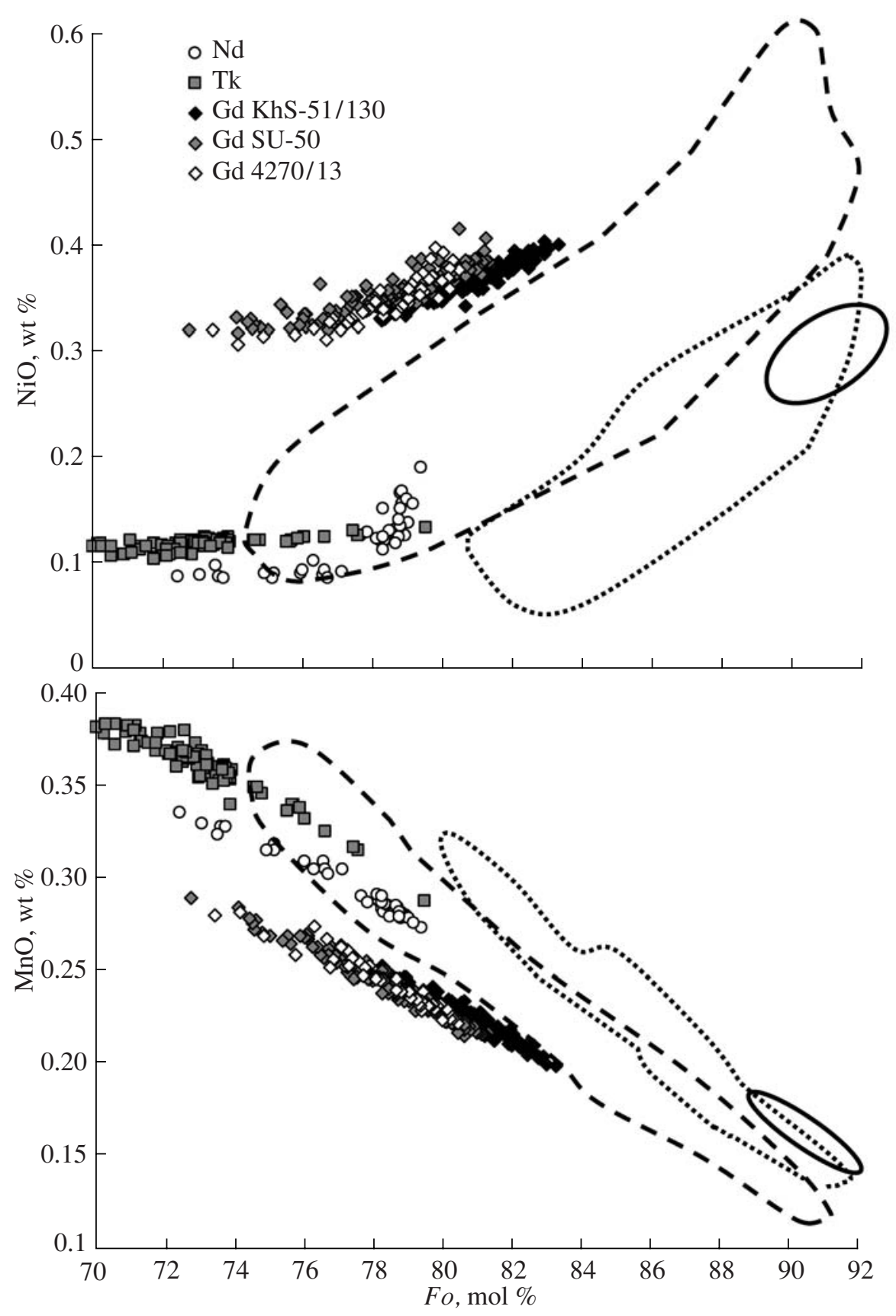

Fig. 4. Compositions of olivine phenocrysts from the magnesian Siberian traps of the Gudchikhinsky (Gd), Nadezhdinsky (Nd), and Tuklonsky (Tk) formations of the Noril'sk region. The solid line encloses the compositional field of olivines in equilibrium with peridotite material. The dotted line encloses the field of the majority of olivine phenocrysts from mid-ocean ridge basalts. The dashed line encloses the field of olivine phenocrysts from intraplate magmas formed beneath the thick lithosphere (more than $70 \mathrm{~km})$. The compositional fields are after Sobolev et al. (2007).

contents, $\mathrm{FeO}_{\text {tot }}=30.84-0.369 \mathrm{SiO}_{2}(R=0.7)$, in the rocks of the Gudchikhinsky Formation containing, similar to the melts, $7-15$ wt \% $\mathrm{MgO}$ (GEOROC; http://georoc.mpch-mainz.gwdg.de/georoc/). The $\mathrm{Fe}^{+2} / \mathrm{Fe}^{+3}$ ratio of melt was determined from the composition of chrome spinel and the model of spinel-melt $\mathrm{Fe}^{+2} / \mathrm{Fe}^{+3}$ partitioning (Maurel and Maurel, 1982). The corrected values are only slightly different from the compositions of quenched inclusions, mainly with respect to $\mathrm{Mg}$ and $\mathrm{Fe}$ contents. Nonetheless, Table 5 reports correction coefficients for olivine-incompatible trace element contents in inclusions, $K_{\text {cor }}$. The coefficient was calculated for each inclusion as a ratio of $\mathrm{Al}_{2} \mathrm{O}_{3}$ contents in the measured and corrected compositions. In order to obtain a corrected value for incompatible element content in trapped melt, values from 


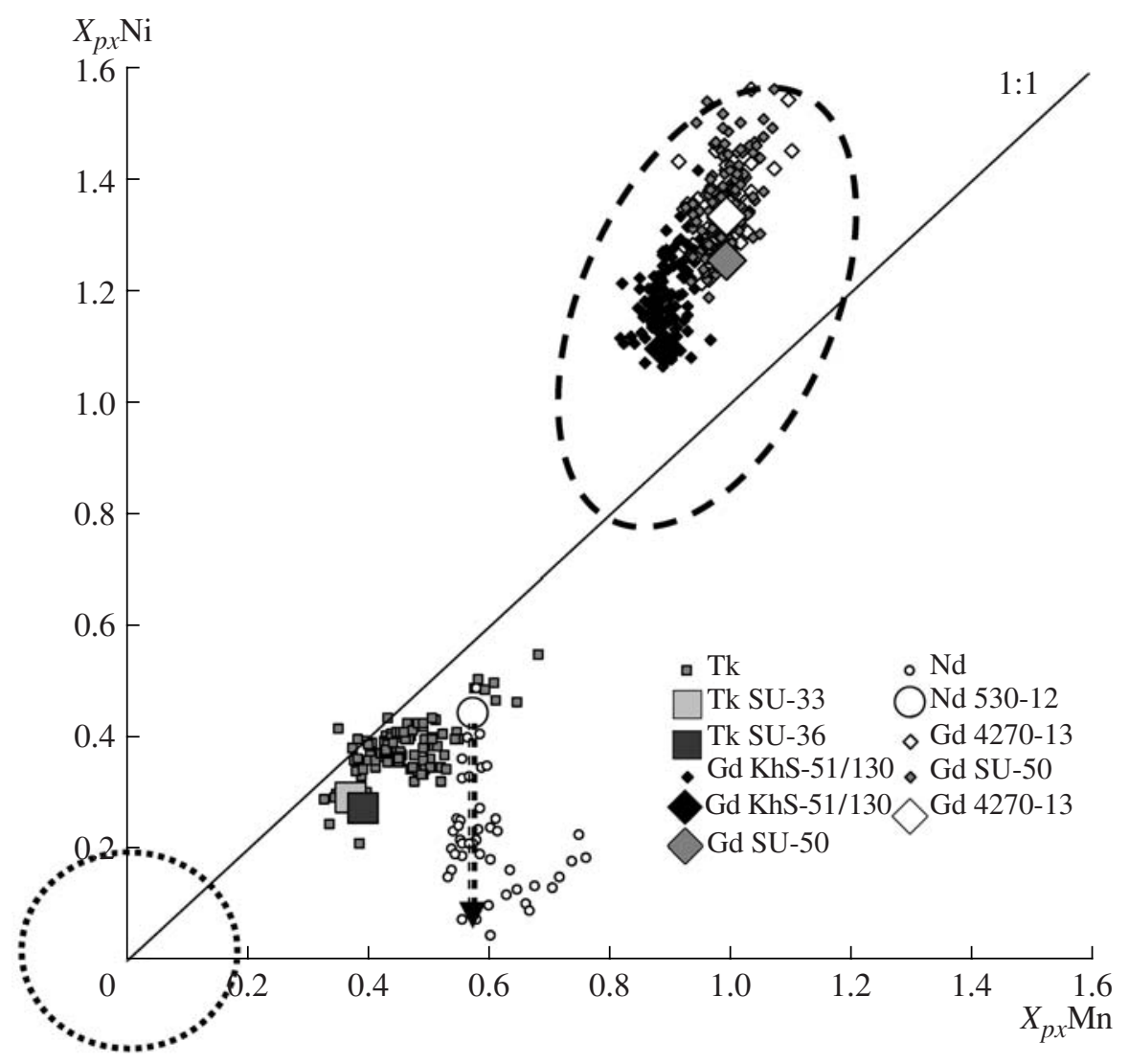

Fig. 5. Fraction of melts derived from the pyroxenite component $\left(X_{p x}\right)$ in the source of the Siberian traps calculated on the basis of the composition of olivine phenocrysts. $X_{p x} \mathrm{Mn}$ and $X_{p x}$ Ni are linear functions of the $\mathrm{Mn} / \mathrm{Fe}$ and $\mathrm{NiO} /(\mathrm{MgO} / \mathrm{FeO})$ ratios in olivine, respectively (Sobolev et al., 2008). Large symbols show the average compositions of the most magnesian olivines (within 1 mol \% from the maximum Mg\# value) from the given sample. The fields show the compositions of olivine equilibrated at low pressures with the melting products of peridotite (dotted contour) and pyroxenite (dashed contour) after Sobolev et al. (2007). The arrow shows the trend of sulfide melt fractionation.

Table 4 should be multiplied by $K_{\text {cor }}$ from Table 5 . Hereafter, we will consider only the corrected compositions. The content of $\mathrm{Ni}$ in melt was calculated from the composition of host olivine and the model of olivine-melt equilibrium by Beattie (1993).

The temperatures of equilibrium between trapped melts and their host olivine lie within the range 1170$1250^{\circ} \mathrm{C}$ (Table 5), close to the range of homogenization temperatures for these inclusions $\left(1180-1290^{\circ} \mathrm{C}\right)$. The oxygen fugacity is unusually low (2.5-3.0 logarithmic units below the $\mathrm{Ni}-\mathrm{NiO}$ buffer), which is related to the strongly reduced spinel composition (Table 3 ).

A monotonous increase in $\mathrm{CaO}$ and $\mathrm{Al}_{2} \mathrm{O}_{3}$ contents at decreasing $\mathrm{MgO}$ (Fig. 7a) suggests that melt evolution was controlled by olivine crystallization without coexisting plagioclase and pyroxene. This fact allowed us to calculate the composition of parental melt by modeling reverse olivine fractionation (see the section Composition of Primary Magmas below). The compositions of inclusions from samples SU-50 and 4270/13 form a single trend with respect to all elements (Fig. 7) and are similar to the compositions of basaltic glasses from Mauna Loa Volcano, Hawaii. Inclusions from sample KhS-51/130 are distinguished by high $\mathrm{SiO}_{2}$ and $\mathrm{K}_{2} \mathrm{O}$; low $\mathrm{CaO}, \mathrm{TiO}_{2}$, and $\mathrm{P}_{2} \mathrm{O}_{5}$; and elevated $\mathrm{Rb}, \mathrm{Ba}, \mathrm{U}$, $\mathrm{Th}, \mathrm{La}$, and $\mathrm{Pb}$ contents (Figs. 7-9); i.e., they are enriched in elements typical of the silicic rocks of the continental crust (Rudnick, 2002). The lithophile element spider diagrams of these inclusions (Fig. 9a) display distinct characteristic anomalies of the continental crust, positive for $\mathrm{Rb}, \mathrm{U}$, and $\mathrm{Pb}$ and negative for $\mathrm{Ta}$, $\mathrm{Nb}$, and $\mathrm{Ti}$. These observations suggest that the melts from which the olivine of sample KhS-51/130 crystallized were significantly contaminated by silicic continental materials, for instance, quartz sandstones. Indications of contamination (elevated contents of $\mathrm{K}, \mathrm{Cl}$, and B) were also observed in some inclusions from sample SU-50 (Fig. 10). However, in that case, the contaminant was different, enriched in $\mathrm{Cl}$ and $\mathrm{K}$ and poor in $\mathrm{Si}$ (probably, evaporite).

The compositions of melt inclusions in olivine from samples SU-50 and 4270/13 containing $\mathrm{Cl}<0.045 \mathrm{wt}$ $\%$ show a very narrow range of all incompatible elements, identical for the two samples (Fig. 9b). No evidence for crustal contamination was observed. The composition of the inclusions is very similar to the 
Table 3. Representative analyses of olivine phenocrysts from the picritic basalts of the Nadezhdinsky and Tuklonsky formations

\begin{tabular}{|c|c|c|c|c|c|c|c|c|c|c|c|c|}
\hline Sample no. & $\mathrm{SiO}_{2}$ & $\mathrm{TiO}_{2}$ & $\mathrm{Al}_{2} \mathrm{O}_{3}$ & $\mathrm{FeO}$ & $\mathrm{MnO}$ & $\mathrm{MgO}$ & $\mathrm{CaO}$ & $\mathrm{NiO}$ & $\mathrm{CoO}$ & $\mathrm{Cr}_{2} \mathrm{O}_{3}$ & Total & Fo \\
\hline 530-247 & 39.3 & & 0.034 & 19.5 & 0.272 & 42.0 & 0.234 & 0.191 & 0.025 & 0.046 & 101.6 & 79.4 \\
\hline $530-187$ & 39.0 & 0.014 & 0.022 & 19.5 & 0.275 & 41.7 & 0.256 & 0.156 & 0.027 & 0.031 & 101.1 & 79.1 \\
\hline 530-138 & 38.9 & 0.014 & 0.023 & 19.6 & 0.277 & 41.5 & 0.254 & 0.139 & 0.026 & 0.038 & 100.9 & 79.0 \\
\hline $530-53$ & 39.0 & 0.015 & 0.034 & 19.7 & 0.278 & 41.6 & 0.255 & 0.161 & 0.026 & 0.042 & 101.1 & 79.0 \\
\hline $530-37$ & 39.1 & 0.013 & 0.025 & 19.7 & 0.279 & 41.6 & 0.256 & 0.126 & 0.027 & 0.034 & 101.3 & 78.9 \\
\hline $530-62$ & 38.9 & 0.016 & 0.028 & 19.8 & 0.280 & 41.4 & 0.251 & 0.138 & 0.028 & 0.046 & 101.0 & 78.8 \\
\hline 530-41 & 39.1 & 0.015 & 0.028 & 19.8 & 0.277 & 41.5 & 0.238 & 0.156 & 0.026 & 0.042 & 101.3 & 78.8 \\
\hline $530-8$ & 39.0 & 0.013 & 0.031 & 19.8 & 0.277 & 41.4 & 0.243 & 0.169 & 0.025 & 0.037 & 101.1 & 78.8 \\
\hline $530-128$ & 38.9 & 0.016 & 0.03 & 19.9 & 0.281 & 41.6 & 0.253 & 0.152 & 0.025 & 0.044 & 101.2 & 78.8 \\
\hline $530-30$ & 38.8 & & 0.026 & 19.7 & 0.278 & 41.2 & 0.239 & 0.167 & 0.025 & 0.041 & 100.7 & 78.8 \\
\hline $530-159$ & 39.0 & 0.015 & 0.028 & 19.8 & 0.281 & 41.4 & 0.257 & 0.135 & 0.025 & 0.04 & 101.1 & 78.8 \\
\hline 530-196 & 38.9 & 0.013 & 0.032 & 19.9 & 0.278 & 41.4 & 0.248 & 0.141 & 0.025 & 0.044 & 101.1 & 78.7 \\
\hline $530-117$ & 39.0 & 0.015 & 0.025 & 19.9 & 0.278 & 41.4 & 0.258 & 0.125 & 0.026 & 0.035 & 101.1 & 78.7 \\
\hline $530-85$ & 39.0 & 0.019 & 0.03 & 19.9 & 0.283 & 41.5 & 0.260 & 0.133 & 0.026 & 0.049 & 101.3 & 78.7 \\
\hline $530-156$ & 38.9 & 0.018 & 0.026 & 20.0 & 0.284 & 41.4 & 0.245 & 0.119 & 0.024 & 0.042 & 101.2 & 78.6 \\
\hline 530-99 & 38.9 & 0.013 & 0.026 & 20.0 & 0.280 & 41.4 & 0.250 & 0.133 & 0.026 & 0.034 & 101.1 & 78.6 \\
\hline $530-100$ & 38.9 & 0.014 & 0.04 & 20.0 & 0.281 & 41.4 & 0.248 & 0.129 & 0.027 & 0.046 & 101.2 & 78.6 \\
\hline $530-142$ & 39.0 & 0.014 & 0.032 & 20.1 & 0.278 & 41.2 & 0.242 & 0.131 & 0.026 & 0.045 & 101.0 & 78.5 \\
\hline $530-60$ & 38.8 & 0.014 & 0.024 & 20.1 & 0.284 & 41.1 & 0.258 & 0.128 & 0.027 & 0.038 & 100.9 & 78.4 \\
\hline $530-126$ & 38.8 & 0.013 & 0.154 & 20.1 & 0.285 & 40.8 & 0.390 & 0.122 & 0.026 & 0.056 & 100.8 & 78.3 \\
\hline 530-59 & 38.9 & 0.013 & 0.066 & 20.2 & 0.281 & 40.9 & 0.283 & 0.152 & 0.024 & 0.052 & 101.0 & 78.3 \\
\hline 530-181 & 39.0 & 0.011 & 0.024 & 20.3 & 0.286 & 41.2 & 0.253 & 0.125 & 0.027 & 0.036 & 101.3 & 78.3 \\
\hline 530-191 & 38.9 & 0.041 & 0.027 & 20.3 & 0.289 & 41.1 & 0.267 & 0.114 & 0.027 & 0.032 & 101.2 & 78.3 \\
\hline $530-52$ & 38.9 & 0.014 & 0.031 & 20.3 & 0.282 & 41.1 & 0.250 & 0.120 & 0.028 & 0.041 & 101.1 & 78.3 \\
\hline $530-9$ & 38.8 & 0.014 & 0.025 & 20.3 & 0.289 & 41.0 & 0.271 & 0.123 & 0.028 & 0.045 & 101.0 & 78.2 \\
\hline $530-146$ & 38.9 & 0.011 & 0.026 & 20.4 & 0.287 & 41.1 & 0.273 & 0.124 & 0.027 & 0.034 & 101.2 & 78.1 \\
\hline 530-163 & 39.0 & 0.014 & 0.023 & 20.5 & 0.290 & 41.2 & 0.277 & 0.124 & 0.027 & 0.035 & 101.6 & 78.1 \\
\hline $530-39$ & 38.8 & 0.013 & 0.035 & 20.6 & 0.286 & 40.7 & 0.256 & 0.130 & 0.027 & 0.041 & 101.0 & 77.8 \\
\hline 530-14 & 38.8 & 0.012 & 0.024 & 20.8 & 0.289 & 40.6 & 0.260 & 0.126 & 0.026 & 0.042 & 101.1 & 77.6 \\
\hline 530-341 & 38.9 & & 0.014 & 21.6 & 0.301 & 40.1 & 0.265 & 0.086 & 0.025 & 0.021 & 101.5 & 76.7 \\
\hline $530-320$ & 38.9 & & 0.022 & 22.3 & 0.308 & 39.8 & 0.260 & 0.095 & 0.028 & 0.025 & 101.9 & 76.0 \\
\hline 530-296 & 38.5 & & 0.015 & 23.1 & 0.314 & 39.2 & 0.261 & 0.086 & 0.028 & 0.015 & 101.6 & 75.1 \\
\hline 530-31 & 38.7 & & 0.024 & 23.1 & 0.314 & 38.8 & 0.257 & 0.092 & 0.028 & 0.024 & 101.5 & 74.9 \\
\hline $530-317$ & 38.5 & & 0.023 & 24.4 & 0.322 & 38.1 & 0.249 & 0.099 & 0.028 & 0.016 & 101.9 & 73.5 \\
\hline 530-345 & 38.3 & & 0.009 & 24.8 & 0.328 & 37.8 & 0.238 & 0.090 & 0.029 & 0.012 & 101.7 & 73.0 \\
\hline SU36c-1-4 & 38.0 & 0.015 & 0.025 & 26.3 & 0.370 & 36.2 & 0.240 & 0.122 & 0.031 & 0.011 & 101.4 & 71.0 \\
\hline SU36c-1-2 & 37.5 & 0.033 & 0.016 & 26.8 & 0.377 & 35.5 & 0.206 & 0.119 & 0.032 & 0.000 & 100.8 & 70.2 \\
\hline SU36a-1-9 & 38.4 & 0.036 & 0.010 & 24.0 & 0.353 & 38.0 & 0.207 & 0.120 & 0.030 & 0.003 & 101.3 & 73.8 \\
\hline SU36a-1-8 & 38.8 & 0.040 & 0.023 & 24.1 & 0.353 & 38.2 & 0.199 & 0.122 & 0.030 & 0.005 & 101.9 & 73.8 \\
\hline SU36a-1-7 & 38.5 & 0.036 & 0.010 & 24.2 & 0.351 & 37.9 & 0.196 & 0.122 & 0.030 & 0.000 & 101.5 & 73.5 \\
\hline SU36a-1-5 & 38.2 & 0.037 & 0.016 & 24.1 & 0.354 & 37.5 & 0.200 & 0.118 & 0.029 & 0.003 & 100.6 & 73.4 \\
\hline SU36a-1-4 & 38.5 & 0.036 & 0.018 & 24.3 & 0.360 & 37.3 & 0.214 & 0.119 & 0.031 & 0.002 & 101.0 & 73.2 \\
\hline SU36a-1-2 & 38.3 & 0.030 & 0.015 & 23.9 & 0.352 & 37.9 & 0.224 & 0.121 & 0.028 & 0.004 & 101.0 & 73.8 \\
\hline SU36a-1-15 & 38.5 & 0.030 & 0.017 & 24.3 & 0.357 & 38.2 & 0.224 & 0.119 & 0.029 & 0.002 & 101.8 & 73.6 \\
\hline SU36a-1-14 & 38.4 & 0.028 & 0.022 & 24.1 & 0.356 & 38.2 & 0.246 & 0.120 & 0.030 & 0.009 & 101.6 & 73.8 \\
\hline SU36a-1-13 & 38.9 & 0.029 & 0.022 & 21.6 & 0.324 & 39.8 & 0.234 & 0.125 & 0.028 & 0.019 & 101.2 & 76.6 \\
\hline SU36a-1-10 & 38.5 & 0.032 & 0.012 & 24.1 & 0.351 & 37.9 & 0.203 & 0.121 & 0.030 & 0.004 & 101.4 & 73.7 \\
\hline SU36a-1-1 & 38.3 & 0.035 & 0.011 & 24.6 & 0.354 & 37.3 & 0.221 & 0.119 & 0.032 & 0.002 & 101.1 & 73.0 \\
\hline SU36-1-7 & 38.1 & 0.019 & 0.017 & 25.9 & 0.372 & 36.5 & 0.256 & 0.117 & 0.031 & 0.002 & 101.3 & 71.5 \\
\hline SU36-1-5 & 38.3 & 0.034 & 0.006 & 26.3 & 0.381 & 36.4 & 0.222 & 0.114 & 0.031 & 0.000 & 101.9 & 71.1 \\
\hline SU36-1-1 & 38.4 & 0.030 & 0.010 & 26.2 & 0.377 & 36.4 & 0.229 & 0.116 & 0.031 & 0.000 & 101.8 & 71.3 \\
\hline
\end{tabular}


Table 3. (Contd.)

\begin{tabular}{|c|c|c|c|c|c|c|c|c|c|c|c|c|}
\hline Sample no. & $\mathrm{SiO}_{2}$ & $\mathrm{TiO}_{2}$ & $\mathrm{Al}_{2} \mathrm{O}_{3}$ & $\mathrm{FeO}$ & $\mathrm{MnO}$ & $\mathrm{MgO}$ & $\mathrm{CaO}$ & $\mathrm{NiO}$ & $\mathrm{CoO}$ & $\mathrm{Cr}_{2} \mathrm{O}_{3}$ & Total & Fo \\
\hline SU33-3a-9 & 38.3 & 0.038 & 0.012 & 24.6 & 0.366 & 37.3 & 0.192 & 0.120 & 0.030 & 0.002 & 100.9 & 73.0 \\
\hline SU33-3a-8 & 38.5 & 0.034 & 0.008 & 24.5 & 0.368 & 37.2 & 0.195 & 0.119 & 0.029 & 0.005 & 101.0 & 73.1 \\
\hline SU33-3a-7 & 38.7 & 0.031 & 0.011 & 24.8 & 0.366 & 37.5 & 0.190 & 0.119 & 0.032 & 0.000 & 101.7 & 72.9 \\
\hline SU33-3a-6 & 38.4 & 0.036 & 0.024 & 25.0 & 0.365 & 37.3 & 0.212 & 0.123 & 0.033 & 0.000 & 101.6 & 72.7 \\
\hline SU33-3a-5 & 38.5 & 0.032 & 0.003 & 24.5 & 0.359 & 37.2 & 0.181 & 0.116 & 0.031 & 0.002 & 101.0 & 73.1 \\
\hline SU33-3a-4 & 38.3 & 0.032 & 0.010 & 24.8 & 0.365 & 37.3 & 0.182 & 0.119 & 0.031 & 0.001 & 101.2 & 72.8 \\
\hline SU33-3a-3 & 38.7 & 0.032 & 0.010 & 24.9 & 0.363 & 37.1 & 0.190 & 0.121 & 0.029 & 0.002 & 101.5 & 72.6 \\
\hline SU33-3a-26 & 38.4 & 0.032 & 0.014 & 25.2 & 0.378 & 36.7 & 0.182 & 0.116 & 0.029 & 0.000 & 101.0 & 72.2 \\
\hline SU33-3a-25 & 38.4 & 0.029 & 0.009 & 24.6 & 0.360 & 37.1 & 0.184 & 0.121 & 0.027 & 0.005 & 100.8 & 72.9 \\
\hline SU33-3a-23 & 38.4 & 0.031 & 0.011 & 24.3 & 0.365 & 37.3 & 0.198 & 0.117 & 0.032 & 0.006 & 100.8 & 73.2 \\
\hline SU33-3a-22 & 38.0 & 0.032 & 0.017 & 25.5 & 0.368 & 36.7 & 0.174 & 0.118 & 0.030 & 0.000 & 100.9 & 72.0 \\
\hline SU33-3a-21 & 38.3 & 0.045 & 0.015 & 25.2 & 0.366 & 37.3 & 0.206 & 0.122 & 0.031 & 0.000 & 101.7 & 72.5 \\
\hline SU33-3a-20 & 38.3 & 0.033 & 0.016 & 25.2 & 0.367 & 37.3 & 0.198 & 0.118 & 0.030 & 0.010 & 101.6 & 72.6 \\
\hline SU33-3a-19 & 38.5 & 0.032 & 0.008 & 24.4 & 0.358 & 37.2 & 0.201 & 0.117 & 0.029 & 0.005 & 100.8 & 73.1 \\
\hline SU33-3a-17 & 38.2 & 0.035 & 0.016 & 24.9 & 0.364 & 37.4 & 0.183 & 0.121 & 0.031 & 0.001 & 101.2 & 72.8 \\
\hline SU33-3a-16 & 38.6 & 0.030 & 0.016 & 24.3 & 0.358 & 38.2 & 0.215 & 0.124 & 0.032 & 0.007 & 101.9 & 73.7 \\
\hline SU33-3a-15 & 38.1 & 0.032 & 0.009 & 25.0 & 0.364 & 37.3 & 0.171 & 0.120 & 0.030 & 0.002 & 101.2 & 72.7 \\
\hline SU33-3a-14 & 38.2 & 0.033 & 0.007 & 24.6 & 0.364 & 37.1 & 0.189 & 0.117 & 0.029 & 0.001 & 100.7 & 72.9 \\
\hline SU33-3a-13 & 37.7 & 0.031 & 0.006 & 24.3 & 0.362 & 36.9 & 0.195 & 0.119 & 0.030 & 0.000 & 99.7 & 73.0 \\
\hline SU33-3a-12 & 38.3 & 0.035 & 0.014 & 25.2 & 0.366 & 37.2 & 0.213 & 0.120 & 0.030 & 0.002 & 101.5 & 72.5 \\
\hline SU33-3a-11 & 38.6 & 0.032 & 0.015 & 25.0 & 0.364 & 37.4 & 0.204 & 0.121 & 0.030 & 0.004 & 101.7 & 72.7 \\
\hline SU33-3a-10 & 38.7 & 0.032 & 0.017 & 24.7 & 0.364 & 37.5 & 0.196 & 0.121 & 0.030 & 0.004 & 101.7 & 73.0 \\
\hline SU33-3a-1 & 38.8 & 0.032 & 0.007 & 22.5 & 0.335 & 39.0 & 0.197 & 0.121 & 0.029 & 0.008 & 101.1 & 75.6 \\
\hline SU33-3-9 & 38.4 & 0.035 & 0.007 & 24.1 & 0.359 & 37.6 & 0.209 & 0.121 & 0.032 & 0.009 & 100.9 & 73.6 \\
\hline SU33-3-7 & 38.2 & 0.039 & 0.009 & 25.6 & 0.377 & 36.5 & 0.177 & 0.119 & 0.031 & 0.002 & 101.0 & 71.8 \\
\hline SU33-3-5 & 38.6 & 0.028 & 0.011 & 24.4 & 0.362 & 37.4 & 0.206 & 0.118 & 0.031 & 0.004 & 101.2 & 73.2 \\
\hline SU33-3-45 & 38.1 & 0.038 & 0.017 & 23.8 & 0.358 & 37.6 & 0.184 & 0.120 & 0.030 & 0.005 & 100.3 & 73.8 \\
\hline SU33-3-44 & 38.6 & 0.028 & 0.008 & 23.9 & 0.354 & 37.8 & 0.221 & 0.119 & 0.028 & 0.013 & 101.1 & 73.9 \\
\hline SU33-3-43 & 38.4 & 0.012 & 0.023 & 23.2 & 0.348 & 38.3 & 0.251 & 0.123 & 0.030 & 0.013 & 100.7 & 74.7 \\
\hline SU33-3-42 & 38.5 & 0.018 & 0.018 & 23.3 & 0.348 & 38.3 & 0.243 & 0.123 & 0.032 & 0.009 & 100.9 & 74.6 \\
\hline SU33-3-41 & 38.1 & 0.035 & 0.009 & 25.2 & 0.368 & 37.0 & 0.202 & 0.119 & 0.030 & 0.001 & 101.1 & 72.4 \\
\hline SU33-3-4 & 38.8 & 0.044 & 0.020 & 22.3 & 0.339 & 39.0 & 0.194 & 0.122 & 0.028 & 0.012 & 101.0 & 75.7 \\
\hline SU33-3-39 & 37.8 & 0.041 & 0.014 & 24.7 & 0.362 & 36.6 & 0.210 & 0.120 & 0.030 & 0.002 & 99.9 & 72.5 \\
\hline SU33-3-38 & 38.1 & 0.033 & 0.015 & 24.9 & 0.365 & 36.8 & 0.203 & 0.120 & 0.031 & 0.000 & 100.6 & 72.5 \\
\hline SU33-3-37 & 38.1 & 0.033 & 0.009 & 24.8 & 0.363 & 36.8 & 0.186 & 0.118 & 0.032 & 0.000 & 100.5 & 72.5 \\
\hline SU33-3-35 & 38.2 & 0.033 & 0.012 & 24.5 & 0.362 & 37.4 & 0.215 & 0.121 & 0.029 & 0.002 & 100.9 & 73.1 \\
\hline SU33-3-33 & 38.4 & 0.032 & 0.015 & 24.5 & 0.361 & 37.7 & 0.167 & 0.124 & 0.030 & 0.002 & 101.3 & 73.3 \\
\hline SU33-3-32 & 38.1 & 0.032 & 0.010 & 24.3 & 0.359 & 37.3 & 0.183 & 0.122 & 0.030 & 0.003 & 100.4 & 73.2 \\
\hline SU33-3-31 & 38.0 & 0.029 & 0.007 & 24.3 & 0.359 & 37.5 & 0.193 & 0.124 & 0.030 & 0.005 & 100.6 & 73.3 \\
\hline SU33-3-30 & 38.4 & 0.022 & 0.011 & 24.5 & 0.359 & 37.6 & 0.243 & 0.119 & 0.029 & 0.008 & 101.2 & 73.2 \\
\hline SU33-3-3 & 38.7 & 0.027 & 0.014 & 23.1 & 0.345 & 38.4 & 0.205 & 0.122 & 0.028 & 0.010 & 100.9 & 74.8 \\
\hline SU33-3-29 & 38.4 & 0.025 & 0.012 & 24.3 & 0.358 & 37.7 & 0.223 & 0.120 & 0.031 & 0.006 & 101.2 & 73.5 \\
\hline SU33-3-28 & 38.3 & 0.036 & 0.022 & 24.7 & 0.353 & 37.3 & 0.195 & 0.122 & 0.030 & 0.000 & 101.0 & 73.0 \\
\hline SU33-3-27 & 38.3 & 0.032 & 0.005 & 24.8 & 0.363 & 37.2 & 0.196 & 0.121 & 0.028 & 0.002 & 101.0 & 72.8 \\
\hline SU33-3-26 & 38.4 & 0.031 & 0.010 & 24.8 & 0.366 & 37.3 & 0.219 & 0.117 & 0.028 & 0.001 & 101.2 & 72.8 \\
\hline SU33-3-25 & 38.3 & 0.031 & 0.003 & 24.6 & 0.367 & 37.1 & 0.196 & 0.120 & 0.028 & 0.000 & 100.7 & 72.9 \\
\hline SU33-3-24 & 38.7 & 0.034 & 0.017 & 24.0 & 0.357 & 38.1 & 0.190 & 0.121 & 0.031 & 0.001 & 101.5 & 73.9 \\
\hline SU33-3-23 & 38.5 & 0.030 & 0.018 & 24.2 & 0.359 & 37.9 & 0.183 & 0.119 & 0.029 & 0.000 & 101.3 & 73.6 \\
\hline SU33-3-22 & 38.5 & 0.030 & 0.012 & 24.1 & 0.355 & 37.7 & 0.185 & 0.122 & 0.029 & 0.001 & 101.1 & 73.6 \\
\hline SU33-3-21 & 38.9 & 0.097 & 0.020 & 23.4 & 0.354 & 35.8 & 0.215 & 0.125 & 0.020 & 0.010 & 98.9 & 73.2 \\
\hline SU33-3-2 & 39.1 & 0.013 & 0.025 & 19.2 & 0.287 & 41.8 & 0.253 & 0.135 & 0.026 & 0.035 & 100.8 & 79.5 \\
\hline SU33-3-19 & 38.9 & 0.031 & 0.006 & 22.2 & 0.337 & 39.2 & 0.198 & 0.124 & 0.029 & 0.011 & 101.0 & 75.9 \\
\hline
\end{tabular}


Table 3. (Contd.)

\begin{tabular}{|c|c|c|c|c|c|c|c|c|c|c|c|c|}
\hline Sample no. & $\mathrm{SiO}_{2}$ & $\mathrm{TiO}_{2}$ & $\mathrm{Al}_{2} \mathrm{O}_{3}$ & $\mathrm{FeO}$ & $\mathrm{MnO}$ & $\mathrm{MgO}$ & $\mathrm{CaO}$ & $\mathrm{NiO}$ & $\mathrm{CoO}$ & $\mathrm{Cr}_{2} \mathrm{O}_{3}$ & Total & Fo \\
\hline SU33-3-18 & 39.1 & 0.029 & 0.011 & 22.2 & 0.331 & 39.5 & 0.204 & 0.126 & 0.029 & 0.012 & 101.6 & 76.1 \\
\hline SU33-3-17 & 38.8 & 0.033 & 0.016 & 22.2 & 0.339 & 38.7 & 0.223 & 0.121 & 0.030 & 0.013 & 100.6 & 75.7 \\
\hline SU33-3-15 & 39.0 & 0.020 & 0.015 & 20.9 & 0.316 & 40.3 & 0.205 & 0.131 & 0.029 & 0.025 & 101.0 & 77.4 \\
\hline SU33-3-14 & 38.5 & 0.035 & 0.003 & 24.1 & 0.357 & 38.0 & 0.198 & 0.121 & 0.030 & 0.008 & 101.4 & 73.8 \\
\hline SU33-3-12 & 38.7 & 0.026 & 0.018 & 20.6 & 0.314 & 40.1 & 0.261 & 0.127 & 0.027 & 0.037 & 100.2 & 77.6 \\
\hline SU33-3-11 & 38.4 & 0.035 & 0.011 & 24.0 & 0.360 & 37.7 & 0.201 & 0.120 & 0.030 & 0.008 & 100.9 & 73.7 \\
\hline SU33-3-10 & 38.5 & 0.034 & 0.014 & 23.9 & 0.353 & 37.9 & 0.193 & 0.126 & 0.030 & 0.015 & 101.1 & 73.9 \\
\hline SU33-1b-8 & 37.8 & 0.033 & 0.007 & 27.9 & 0.377 & 35.5 & 0.196 & 0.120 & 0.033 & 0.001 & 101.8 & 69.4 \\
\hline SU33-1b-3-5 & 37.9 & 0.031 & 0.015 & 26.7 & 0.371 & 35.9 & 0.202 & 0.116 & 0.029 & 0.017 & 101.3 & 70.6 \\
\hline SU33-1b-3-2 & 38.0 & 0.032 & 0.008 & 27.3 & 0.380 & 35.8 & 0.196 & 0.117 & 0.029 & 0.000 & 101.8 & 70.0 \\
\hline SU33-1a-1-8 & 37.9 & 0.029 & 0.007 & 24.3 & 0.350 & 37.5 & 0.181 & 0.117 & 0.029 & 0.005 & 100.4 & 73.4 \\
\hline SU33-1a-1-16 & 38.0 & 0.032 & 0.017 & 23.7 & 0.339 & 37.6 & 0.167 & 0.115 & 0.029 & 0.020 & 100.0 & 73.9 \\
\hline SU33-1a-1-1 & 37.6 & 0.030 & 0.023 & 25.1 & 0.359 & 36.8 & 0.162 & 0.113 & 0.029 & 0.007 & 100.3 & 72.4 \\
\hline SU31-4-1-2 & 37.4 & 0.028 & 0.012 & 27.7 & 0.380 & 35.1 & 0.171 & 0.109 & 0.031 & 0.001 & 100.9 & 69.3 \\
\hline SU31-2a-9 & 38.5 & 0.031 & 0.007 & 25.3 & 0.364 & 37.4 & 0.182 & 0.113 & 0.029 & 0.004 & 101.9 & 72.5 \\
\hline SU31-2a-6 & 38.2 & 0.033 & 0.009 & 25.4 & 0.369 & 37.3 & 0.186 & 0.110 & 0.030 & 0.004 & 101.6 & 72.4 \\
\hline SU31-2a-5 & 38.4 & 0.032 & 0.010 & 25.4 & 0.367 & 37.5 & 0.170 & 0.110 & 0.030 & 0.001 & 102.0 & 72.5 \\
\hline SU31-2a-4 & 38.3 & 0.030 & 0.018 & 25.4 & 0.368 & 37.5 & 0.169 & 0.110 & 0.028 & 0.004 & 101.9 & 72.5 \\
\hline SU31-2a-2 & 38.2 & 0.031 & 0.014 & 25.1 & 0.363 & 37.5 & 0.183 & 0.110 & 0.030 & 0.005 & 101.5 & 72.7 \\
\hline SU31-2a-12 & 38.1 & 0.029 & 0.015 & 25.8 & 0.368 & 36.7 & 0.174 & 0.106 & 0.029 & 0.000 & 101.3 & 71.7 \\
\hline SU31-2a-10 & 38.3 & 0.030 & 0.015 & 25.2 & 0.367 & 37.4 & 0.175 & 0.111 & 0.029 & 0.001 & 101.7 & 72.6 \\
\hline SU31-2a-1 & 38.4 & 0.033 & 0.019 & 25.1 & 0.363 & 37.0 & 0.208 & 0.112 & 0.029 & 0.002 & 101.3 & 72.4 \\
\hline SU31-2-4 & 38.1 & 0.023 & 0.010 & 26.6 & 0.378 & 36.4 & 0.181 & 0.109 & 0.031 & 0.000 & 101.9 & 70.9 \\
\hline SU31-2-3 & 37.9 & 0.024 & 0.016 & 26.9 & 0.382 & 36.1 & 0.171 & 0.107 & 0.030 & 0.000 & 101.6 & 70.5 \\
\hline SU31-2-2-9 & 37.7 & 0.029 & 0.008 & 25.3 & 0.366 & 36.8 & 0.183 & 0.107 & 0.028 & 0.003 & 100.5 & 72.1 \\
\hline SU31-2-2-6 & 38.0 & 0.030 & 0.010 & 25.7 & 0.368 & 37.1 & 0.165 & 0.108 & 0.029 & 0.002 & 101.6 & 72.0 \\
\hline SU31-2-2-5 & 37.9 & 0.031 & 0.016 & 25.5 & 0.366 & 37.0 & 0.203 & 0.114 & 0.027 & 0.000 & 101.2 & 72.1 \\
\hline SU31-2-2-12 & 37.6 & 0.027 & 0.015 & 25.7 & 0.372 & 36.6 & 0.188 & 0.105 & 0.030 & 0.002 & 100.6 & 71.7 \\
\hline SU31-2-2-11 & 37.8 & 0.023 & 0.003 & 26.2 & 0.379 & 36.2 & 0.172 & 0.110 & 0.031 & 0.001 & 101.0 & 71.1 \\
\hline SU31-2-2-10 & 37.6 & 0.024 & 0.006 & 26.5 & 0.381 & 36.2 & 0.164 & 0.109 & 0.031 & 0.000 & 101.0 & 70.9 \\
\hline SU31-2-2-1 & 38.0 & 0.030 & 0.010 & 25.5 & 0.367 & 37.1 & 0.197 & 0.109 & 0.028 & 0.005 & 101.4 & 72.2 \\
\hline
\end{tabular}

Note: Here and in Tables 4 and 5, blanks mean that elements not determined.

composition of melts with similar $\mathrm{Mg}$ contents from Mauna Loa Volcano, Hawaii.

\section{Volatile Components in Melts}

The melt inclusions in olivine from sample SU-50 and the majority of inclusions in olivine from sample KhS-51/130 show anomalously low $\mathrm{H}_{2} \mathrm{O}$ contents (Fig. 10), which is probably related to the near-surface degassing of crystallizing magmas. The inclusions in olivine from sample 4270/13 show somewhat higher $\mathrm{H}_{2} \mathrm{O}$ contents (up to 0.25 wt \%), comparable with estimates obtained from the concentration of an element with similar incompatibility, e.g., Ce (Dixon et al., 2002). Consequently, they can be considered as the initial characteristics of undegassed magmas. This concentration level is also similar to the minimum $\mathrm{H}_{2} \mathrm{O}$ contents in the glasses of Mauna Loa, Hawaii.

The melt inclusions in olivine from sample KhS51/130 have extremely low $\mathrm{Cl}$ contents, which, similar to $\mathrm{H}_{2} \mathrm{O}$, probably result from near-surface degassing (Fig. 10). The compositions of inclusions in olivine from sample SU-50 form a steep trend of $\mathrm{Cl}$ accumulation with increasing $\mathrm{K}_{2} \mathrm{O}$ content. The contents of $\mathrm{Cl}$ reach remarkably high levels. The compositions of inclusions from sample 4270/13 lie at the beginning of the $\mathrm{Cl}$ accumulation trend and are comparable in this respect to the $\mathrm{Cl}$ richest glasses of Mauna Loa, Hawaii.

A characteristic feature of all the melt inclusions is elevated boron content, which reaches the maximum values in the $\mathrm{Cl}$ richest inclusions from sample SU-50.

All of the inclusions show low $\mathrm{S}$ contents, more than 2-3 times lower than the level of basaltic melt saturation in sulfide liquid (Fig. 10).

Owing to early degassing, $\mathrm{CO}_{2}$ content in low-pressure melts is not representative for parental magmas. However, $\mathrm{CO}_{2}$ content in an undegassed melt can be estimated from the content of a nonvolatile element of similar incompatibility $(\mathrm{Nb})$ using the data of Saal et al. (2002). Given a $\mathrm{CO}_{2} / \mathrm{Nb}$ value of 240 reported by these authors, the initial level of $\mathrm{CO}_{2}$ content can be estimated as $\sim 0.25 \mathrm{wt} \%$. 

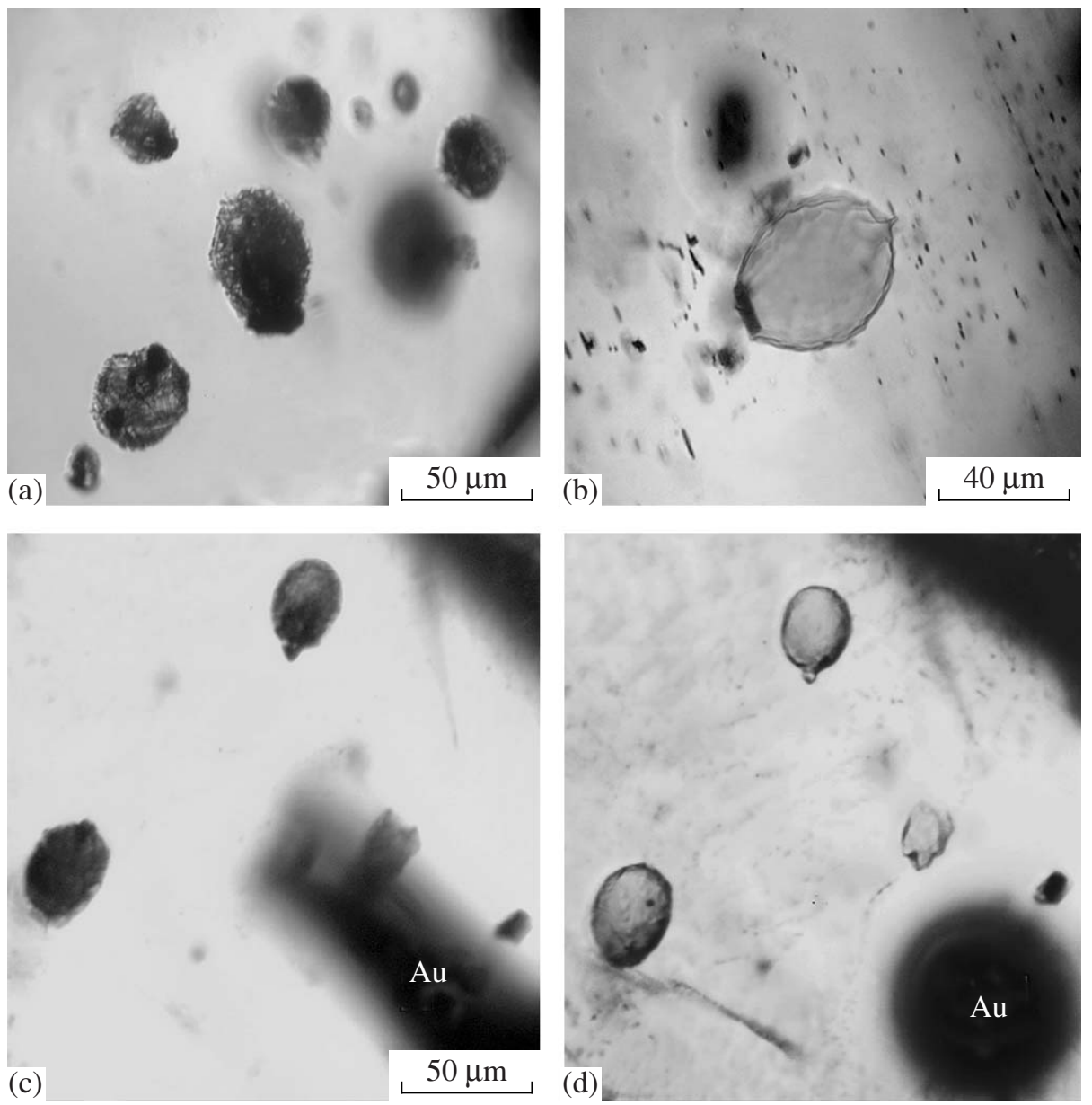

Fig. 6. Melt inclusions in olivine phenocrysts from sample KhS-51/130 of the Gudchikhinsky Formation of the Noril'sk region. (a) Partly crystallized primary inclusions in olivine at $T=270^{\circ} \mathrm{C}$ consisting of acicular clinopyroxene crystals, interstitial glass, opaque isometric spinel crystals, and a spherical fluid phase. (b) Homogenized melt inclusion quenched at $T=1250^{\circ} \mathrm{C}$ (photomicrograph at room temperature) containing a flattened crystal of xenogenic spinel. (c) and (d) primary melt inclusions in olivine at temperatures of $T=200^{\circ} \mathrm{C}$ and $T=1240^{\circ} \mathrm{C}$, respectively. Au is pure gold foil used for the visually controlled calibration of the thermocouple in each experiment. The small spherical fluid specs in the inclusions of photomicrograph (d) are fluid phase immediately before the homogenization of inclusions.

\section{Composition of Primary Magmas}

The primary melts of the Gudchikhinsky rocks can be reconstructed on the basis of the compositions of melt inclusions with the minimum indications for crustal contamination. Such inclusions were analyzed in olivine from samples SU-50 and 4270/13 and show the lowest contents of $\mathrm{Cl}$ and other highly incompatible elements (Figs. 7, 8, 9b). For these inclusions, we utilized the algorithm of reverse olivine fractionation to equilibrium with the most magnesian olivine (Sobolev and Danyushevsky, 1994) detected in the rocks of the Gudchikhinsky Formation, $\mathrm{Fo}_{84}$ (Sobolev et al., 2007 and this study). Calculations were carried out by the Petrolog software (Danyushevsky, 2001) using the models described above in the section Crystallization Conditions and Melt Composition. The $\mathrm{MgO}$ content and equilibrium temperature for the obtained composi- tions could be lower than in the real primary melts, if a more magnesian olivine crystallized in the system, but was not detected in the samples despite the statistically large data set (more than 400 analyzed olivine grains). The addition of olivine results in a considerable increase in $\mathrm{Ni}$ content in the melt; therefore, the maximum amount of added olivine must be limited by the concentration of $\mathrm{Ni}$ in melts equilibrated with reaction pyroxenite (Fig. 11). Since the compositions of pyroxenite-derived melts form a field in the $\mathrm{Ni}-\mathrm{MgO}$ coordinates, the compositions of primary melts were recalculated to its lower ( $G d$ PM min) and upper ( $G d$ PM max) boundaries. The estimated primary melts (Table 6) are in equilibrium at atmospheric pressure with olivine $\mathrm{Fo}_{84-87}\left(\mathrm{Fo}_{85.5}\right.$ on average $)$ and are chemically equivalent to tholeiitic picrites with $48-49 \mathrm{wt} \% \mathrm{SiO}_{2}$ (48.7 on average) and 11-14 wt \% MgO (12.7 on average). 
Table 4. Compositions of melt inclusions and host olivines from the picrites of the Gudchikhinsky Formation

\begin{tabular}{|c|c|c|c|c|c|c|c|c|c|c|}
\hline Component & SU50-3 & SU50-4 & SU50-5 & SU50-6 & SU50-7 & SU50-8 & SU50-9 & \begin{tabular}{|l|} 
SU50-10 \\
\end{tabular} & \begin{tabular}{|l|} 
SU50-11 \\
\end{tabular} & SU50-12 \\
\hline \multicolumn{11}{|c|}{ Melt inclusions } \\
\hline $\mathrm{SiO}_{2}$ & 50.76 & 50.92 & 51.05 & 51.06 & 50.25 & 51.24 & 51.26 & 50.52 & 51.16 & 50.45 \\
\hline $\mathrm{TiO}_{2}$ & 2.29 & 2.56 & 2.22 & 2.24 & 2.63 & 2.26 & 2.28 & 2.30 & 2.38 & 2.35 \\
\hline $\mathrm{Al}_{2} \mathrm{O}_{3}$ & 13.01 & 12.48 & 13.35 & 13.09 & 12.87 & 13.16 & 13.33 & 12.71 & 13.34 & 13.27 \\
\hline $\mathrm{FeO}$ & 9.46 & 10.05 & 8.82 & 8.57 & 9.02 & 8.80 & 8.74 & 9.66 & 8.19 & 8.15 \\
\hline $\mathrm{MnO}$ & 0.13 & 0.13 & 0.11 & 0.13 & 0.11 & 0.12 & 0.14 & 0.10 & 0.13 & 0.10 \\
\hline $\mathrm{MgO}$ & 9.85 & 9.62 & 9.50 & 9.71 & 9.96 & 9.90 & 9.88 & 9.99 & 9.67 & 9.74 \\
\hline $\mathrm{CaO}$ & 10.88 & 10.22 & 11.26 & 11.39 & 11.18 & 11.35 & 11.13 & 10.91 & 11.54 & 11.41 \\
\hline $\mathrm{Na}_{2} \mathrm{O}$ & 2.33 & 2.42 & 2.45 & 2.23 & 2.27 & 2.29 & 2.40 & 2.30 & 2.34 & 2.33 \\
\hline $\mathrm{K}_{2} \mathrm{O}$ & 0.37 & 0.43 & 0.40 & 0.50 & 0.44 & 0.45 & 0.39 & 0.35 & 0.40 & 0.39 \\
\hline $\mathrm{P}_{2} \mathrm{O}_{5}$ & 0.21 & 0.25 & 0.19 & 0.23 & 0.25 & 0.19 & 0.21 & 0.21 & 0.20 & 0.21 \\
\hline $\mathrm{S}, \mathrm{wt} \%$ & 0.04 & 0.05 & 0.04 & 0.06 & 0.06 & 0.04 & 0.05 & 0.03 & 0.03 & 0.04 \\
\hline $\mathrm{Cl}$, wt $\%$ & 0.041 & 0.072 & 0.101 & 0.205 & 0.057 & 0.120 & 0.074 & 0.046 & 0.074 & 0.056 \\
\hline Total & 99.38 & 99.20 & 99.49 & 99.42 & 99.09 & 99.92 & 99.88 & 99.12 & 99.44 & 98.49 \\
\hline$\overline{\mathrm{NiO}}$ & 0.048 & 0.038 & 0.046 & 0.031 & 0.057 & 0.049 & 0.042 & 0.047 & 0.045 & 0.048 \\
\hline $\mathrm{Cr}_{2} \mathrm{O}_{3}$ & 0.185 & 0.100 & 0.187 & 0.219 & 0.177 & 0.188 & 0.208 & 0.181 & 0.150 & 0.153 \\
\hline$\overline{\mathrm{TiO}_{2}, \text { wt } \%}$ & 2.27 & 2.30 & 2.05 & 2.14 & & 2.24 & 2.23 & 2.26 & 2.36 & 2.21 \\
\hline $\mathrm{H}_{2} \mathrm{O}$, wt $\%$ & 0.05 & 0.07 & 0.03 & 0.03 & & 0.05 & 0.03 & 0.06 & 0.04 & 0.03 \\
\hline B & 4.0 & 4.7 & 5.4 & 7.1 & & 6.5 & 4.9 & 4.0 & 5.3 & 4.3 \\
\hline $\mathrm{Li}$ & 5.8 & 6.2 & 4.3 & 4.9 & & 4.4 & 4.4 & 5.6 & 5.0 & 4.9 \\
\hline$\overline{\mathrm{Rb}}$ & 7.05 & 9.57 & 10.85 & 11.48 & 10.76 & 11.71 & 8.27 & 7.58 & 9.31 & 8.39 \\
\hline $\mathrm{Ba}$ & 71.7 & 85.1 & 83.9 & 99.7 & 84.7 & 84.7 & 76.1 & 69.2 & 77.5 & 71.6 \\
\hline $\mathrm{Th}$ & 1.00 & 1.22 & 1.26 & 1.39 & 1.19 & 1.24 & 0.96 & 1.02 & 1.15 & 1.02 \\
\hline $\mathrm{U}$ & 0.26 & 0.33 & 0.35 & 0.39 & 0.33 & 0.33 & 0.32 & 0.28 & 0.31 & 0.32 \\
\hline $\mathrm{Nb}$ & 9.85 & 11.43 & 10.23 & 11.71 & 12.90 & 10.23 & 9.48 & 9.90 & 10.58 & 10.10 \\
\hline $\mathrm{Ta}$ & 0.71 & 0.75 & 0.69 & 0.77 & 0.83 & 0.68 & 0.63 & 0.66 & 0.69 & 0.68 \\
\hline $\mathrm{La}$ & 10.51 & 12.21 & 11.11 & 12.68 & 12.49 & 11.27 & 10.39 & 10.27 & 10.56 & 10.19 \\
\hline $\mathrm{Ce}$ & 28.13 & 31.10 & 27.96 & 31.98 & 32.35 & 27.31 & 26.26 & 26.07 & 27.97 & 26.67 \\
\hline $\mathrm{Pb}$ & 1.35 & 1.87 & 1.81 & 1.90 & 1.93 & 1.93 & 1.58 & 1.41 & 1.63 & 2.46 \\
\hline $\operatorname{Pr}$ & 4.03 & 4.75 & 4.02 & 4.60 & 4.86 & 4.02 & 3.71 & 3.94 & 4.19 & 3.93 \\
\hline $\mathrm{Nd}$ & 19.92 & 23.73 & 20.80 & 21.42 & 23.70 & 20.11 & 19.70 & 19.93 & 20.19 & 19.05 \\
\hline $\mathrm{Sr}$ & 297 & 368 & 343 & 355 & 387 & 322 & 292 & 299 & 313 & 302 \\
\hline $\mathrm{Sm}$ & 5.56 & 6.63 & 6.14 & 5.41 & 6.50 & 5.45 & 5.64 & 5.76 & 5.84 & 5.53 \\
\hline $\mathrm{Zr}$ & 146 & 173 & 148 & 153 & 186 & 143 & 132 & 143 & 150 & 147 \\
\hline Hf & 3.65 & 4.63 & 3.90 & 4.21 & 4.62 & 3.63 & 3.64 & 3.74 & 3.99 & 3.85 \\
\hline $\mathrm{Eu}$ & 2.02 & 2.22 & 1.96 & 1.97 & 2.08 & 1.82 & 1.81 & 1.82 & 1.98 & 1.89 \\
\hline $\mathrm{Ti}$ & 14108 & 15850 & 13939 & 14608 & 16584 & 14292 & 13765 & 14195 & 15210 & 14787 \\
\hline $\mathrm{Gd}$ & 6.04 & 7.29 & 6.43 & 6.22 & 6.85 & 6.11 & 5.97 & 6.25 & 6.01 & 6.19 \\
\hline $\mathrm{Tb}$ & 0.97 & 1.15 & 1.01 & 0.96 & 1.05 & 0.93 & 0.98 & 0.92 & 0.92 & 0.97 \\
\hline Dy & 5.67 & 6.62 & 5.79 & 5.82 & 5.86 & 5.84 & 5.29 & 5.54 & 5.54 & 5.56 \\
\hline Ho & 1.09 & 1.26 & 1.09 & 1.06 & 1.08 & 1.06 & 0.93 & 1.06 & 0.98 & 0.99 \\
\hline $\mathrm{Y}$ & 26.83 & 33.81 & 29.22 & 27.43 & 30.44 & 27.80 & 26.43 & 26.02 & 26.03 & 26.40 \\
\hline Er & 2.65 & 3.44 & 2.94 & 2.74 & 2.82 & 2.59 & 2.43 & 2.72 & 2.56 & 2.71 \\
\hline $\mathrm{Tm}$ & 0.35 & 0.43 & 0.34 & 0.33 & 0.35 & 0.34 & 0.32 & 0.31 & 0.32 & 0.32 \\
\hline $\mathrm{Yb}$ & 1.96 & 2.75 & 2.13 & 2.23 & 2.04 & 2.03 & 1.95 & 1.94 & 2.13 & 2.00 \\
\hline $\mathrm{Lu}$ & 0.29 & 0.39 & 0.31 & 0.28 & 0.29 & 0.27 & 0.27 & 0.27 & 0.26 & 0.29 \\
\hline \multicolumn{11}{|c|}{ Host olivine } \\
\hline Fo & 79.62 & 77.42 & 80.40 & 81.24 & 79.82 & 80.15 & 80.43 & 78.86 & 81.01 & 80.45 \\
\hline $\mathrm{SiO}_{2}$ & 38.64 & 38.64 & 38.90 & 39.04 & 39.12 & 39.21 & 39.40 & 39.07 & 39.23 & 39.02 \\
\hline $\mathrm{TiO}_{2}$ & 0.008 & 0.019 & 0.011 & 0.012 & 0.011 & 0.012 & 0.008 & 0.008 & 0.012 & 0.016 \\
\hline $\mathrm{Al}_{2} \mathrm{O}_{3}$ & 0.024 & 0.027 & 0.028 & 0.029 & 0.028 & 0.025 & 0.027 & 0.023 & 0.023 & 0.024 \\
\hline $\mathrm{FeO}$ & 19.07 & 21.00 & 18.47 & 17.83 & 19.06 & 18.77 & 18.47 & 19.83 & 17.95 & 18.43 \\
\hline $\mathrm{MnO}$ & 0.230 & 0.263 & 0.220 & 0.216 & 0.230 & 0.227 & 0.224 & 0.247 & 0.216 & 0.220 \\
\hline $\mathrm{MgO}$ & 41.79 & 40.40 & 42.52 & 43.32 & 42.31 & 42.28 & 42.59 & 41.51 & 42.96 & 42.58 \\
\hline $\mathrm{CaO}$ & 0.294 & 0.302 & 0.293 & 0.298 & 0.300 & 0.304 & 0.294 & 0.287 & 0.292 & 0.297 \\
\hline $\mathrm{NiO}$ & 0.360 & 0.317 & 0.386 & 0.385 & 0.357 & 0.374 & 0.382 & 0.359 & 0.389 & 0.381 \\
\hline $\mathrm{Cr}_{2} \mathrm{O}_{3}$ & 0.045 & 0.033 & 0.048 & 0.048 & 0.049 & 0.040 & 0.048 & 0.047 & 0.047 & 0.039 \\
\hline Total & 100.47 & 101.01 & 100.90 & 101.20 & 101.49 & 101.26 & 101.46 & 101.40 & 101.14 & 101.03 \\
\hline
\end{tabular}


Table 4. (Contd.)

\begin{tabular}{|c|c|c|c|c|c|c|c|c|c|c|}
\hline Component & SU50-13 & SU50-201 & SU50-202 & SU50-203 & SU50-204 & SU50-205 & SU50-206 & SU50-207 & SU50-208 & $4270-1$ \\
\hline \multicolumn{11}{|c|}{ Melt inclusions } \\
\hline $\mathrm{SiO}_{2}$ & 50.63 & 50.09 & 50.39 & 50.04 & 50.59 & 50.53 & 50.28 & 50.44 & 50.63 & 50.09 \\
\hline $\mathrm{TiO}_{2}$ & 2.29 & 2.30 & 2.37 & 2.42 & 2.30 & 2.33 & 2.36 & 2.21 & 2.29 & 2.30 \\
\hline $\mathrm{Al}_{2} \mathrm{O}_{3}$ & 12.94 & 12.73 & 12.84 & 13.32 & 12.83 & 12.80 & 12.79 & 13.00 & 12.94 & 12.73 \\
\hline $\mathrm{FeO}$ & 9.39 & 9.99 & 9.69 & 8.41 & 9.90 & 9.71 & 10.20 & 9.99 & 9.39 & 9.99 \\
\hline $\mathrm{MnO}$ & 0.13 & 0.13 & 0.14 & 0.11 & 0.13 & 0.13 & 0.14 & 0.15 & 0.13 & 0.13 \\
\hline $\mathrm{MgO}$ & 9.78 & 9.70 & 10.05 & 9.91 & 9.84 & 9.77 & 9.37 & 9.11 & 9.78 & 9.70 \\
\hline $\mathrm{CaO}$ & 10.77 & 11.22 & 11.21 & 11.16 & 10.77 & 11.17 & 11.27 & 10.69 & 10.77 & 11.22 \\
\hline $\mathrm{Na}_{2} \mathrm{O}$ & 2.46 & 2.19 & 2.12 & 2.26 & 2.29 & 2.07 & 2.07 & 2.46 & 2.46 & 2.19 \\
\hline $\mathrm{K}_{2} \mathrm{O}$ & 0.49 & 0.34 & 0.34 & 0.38 & 0.37 & 0.36 & 0.36 & 0.35 & 0.49 & 0.34 \\
\hline $\mathrm{P}_{2} \mathrm{O}_{5}$ & 0.21 & 0.19 & 0.22 & 0.23 & 0.22 & 0.20 & 0.23 & 0.19 & 0.21 & 0.19 \\
\hline $\mathrm{S}, \mathrm{wt} \%$ & 0.05 & 0.04 & 0.05 & 0.06 & 0.05 & 0.03 & 0.06 & 0.04 & 0.05 & 0.04 \\
\hline $\mathrm{Cl}$, wt $\%$ & 0.133 & 0.035 & 0.039 & 0.066 & 0.047 & 0.043 & 0.043 & 0.066 & 0.133 & 0.035 \\
\hline Total & 99.27 & 98.97 & 99.48 & 98.37 & 99.34 & 99.14 & 99.19 & 98.69 & 99.27 & 98.97 \\
\hline $\mathrm{NiO}$ & 0.033 & 0.043 & 0.047 & 0.052 & 0.044 & 0.044 & 0.040 & 0.041 & 0.033 & 0.043 \\
\hline $\mathrm{Cr}_{2} \mathrm{O}_{3}$ & 0.129 & 0.179 & 0.159 & 0.153 & 0.184 & 0.206 & 0.188 & 0.208 & 0.129 & 0.179 \\
\hline $\mathrm{TiO}_{2}$, wt $\%$ & 2.20 & & & & & & & & 2.20 & \\
\hline $\mathrm{H}_{2} \mathrm{O}$, wt $\%$ & 0.04 & & & & & & & & 0.04 & \\
\hline & 6.5 & & & & & & & & 6.5 & \\
\hline $\mathrm{Li}$ & 7.4 & & & & & & & & 7.4 & \\
\hline $\mathrm{Rb}$ & 11.32 & 7.78 & 7.50 & 8.90 & 7.24 & 8.18 & 7.27 & 8.11 & 11.32 & 7.78 \\
\hline $\mathrm{Ba}$ & 93.7 & 73.6 & 71.9 & 77.0 & 69.6 & 76.6 & 73.6 & 72.4 & 93.7 & 73.6 \\
\hline $\mathrm{Th}$ & 1.34 & 1.00 & 0.94 & 1.11 & 0.97 & 1.11 & 1.00 & 1.03 & 1.34 & 1.00 \\
\hline $\mathrm{U}$ & 0.36 & 0.28 & 0.28 & 0.32 & 0.29 & 0.30 & 0.30 & 0.26 & 0.36 & 0.28 \\
\hline $\mathrm{Nb}$ & 11.27 & 10.28 & 10.08 & 10.55 & 9.65 & 9.96 & 9.91 & 9.28 & 11.27 & 10.28 \\
\hline $\mathrm{Ta}$ & 0.73 & 0.66 & 0.67 & 0.72 & 0.65 & 0.68 & 0.70 & 0.61 & 0.73 & 0.66 \\
\hline $\mathrm{La}$ & 12.21 & 10.41 & 10.43 & 11.07 & 10.39 & 10.36 & 10.38 & 10.41 & 12.21 & 10.41 \\
\hline $\mathrm{Ce}$ & 29.99 & 26.76 & 26.76 & 28.33 & 26.87 & 27.11 & 27.38 & 26.65 & 29.99 & 26.76 \\
\hline $\mathrm{Pb}$ & 2.03 & 1.59 & 1.46 & 1.76 & 1.48 & 1.57 & 1.51 & 1.55 & 2.03 & 1.59 \\
\hline $\operatorname{Pr}$ & 4.31 & 3.94 & 4.01 & 4.29 & 4.09 & 3.98 & 3.84 & 4.01 & 4.31 & 3.94 \\
\hline $\mathrm{Nd}$ & 21.35 & 20.27 & 20.30 & 21.49 & 18.87 & 20.46 & 20.29 & 18.73 & 21.35 & 20.27 \\
\hline $\mathrm{Sr}$ & 325 & 308 & 299 & 320 & 312 & 313 & 313 & 304 & 325 & 308 \\
\hline $\mathrm{Sm}$ & 5.79 & 5.49 & 5.85 & 6.01 & 5.70 & 5.75 & 5.69 & 5.96 & 5.79 & 5.49 \\
\hline $\mathrm{Zr}$ & 147 & 147 & 144 & 155 & 149 & 148 & 149 & 141 & 147 & 147 \\
\hline Hf & 4.03 & 4.09 & 3.92 & 4.21 & 3.84 & 4.02 & 3.87 & 3.75 & 4.03 & 4.09 \\
\hline $\mathrm{Eu}$ & 1.99 & 1.97 & 1.86 & 1.96 & 1.87 & 1.85 & 1.97 & 2.03 & 1.99 & 1.97 \\
\hline $\mathrm{Ti}$ & 14244 & 14927 & 14896 & 15370 & 14218 & 14274 & 14543 & 13566 & 14244 & 14927 \\
\hline $\mathrm{Gd}$ & 6.43 & 6.20 & 6.38 & 6.69 & 6.13 & 6.06 & 5.86 & 6.32 & 6.43 & 6.20 \\
\hline $\mathrm{Tb}$ & 1.01 & 0.95 & 0.96 & 0.99 & 0.99 & 0.93 & 0.95 & 1.03 & 1.01 & 0.95 \\
\hline Dy & 6.36 & 5.86 & 5.74 & 5.92 & 5.73 & 5.71 & 5.70 & 5.64 & 6.36 & 5.86 \\
\hline Ho & 1.17 & 1.03 & 1.04 & 1.09 & 1.01 & 1.06 & 1.08 & 1.01 & 1.17 & 1.03 \\
\hline $\mathrm{Y}$ & 29.75 & 27.26 & 26.57 & 27.20 & 26.90 & 26.93 & 26.95 & 26.92 & 29.75 & 27.26 \\
\hline $\mathrm{Er}$ & 3.08 & 2.65 & 2.68 & 2.69 & 2.55 & 2.68 & 2.72 & 2.60 & 3.08 & 2.65 \\
\hline $\mathrm{Tm}$ & 0.39 & 0.33 & 0.33 & 0.34 & 0.33 & 0.34 & 0.31 & 0.34 & 0.39 & 0.33 \\
\hline $\mathrm{Yb}$ & 2.43 & 2.05 & 2.07 & 2.10 & 2.15 & 2.21 & 2.02 & 1.99 & 2.43 & 2.05 \\
\hline $\mathrm{Lu}$ & 0.31 & 0.28 & 0.27 & 0.29 & 0.27 & 0.30 & 0.28 & 0.30 & $\mathrm{Lu}$ & 0.31 \\
\hline \multicolumn{11}{|c|}{ Host olivine } \\
\hline Fo & 78.06 & 77.07 & 77.66 & 81.25 & 79.85 & 78.30 & 79.14 & 79.36 & 80.55 & 80.41 \\
\hline $\mathrm{SiO}_{2}$ & 38.77 & 38.42 & 38.94 & 39.39 & 39.57 & 39.11 & 39.43 & 38.70 & 39.35 & 39.04 \\
\hline $\mathrm{TiO}_{2}$ & 0.008 & 0.016 & 0.011 & 0.011 & 0.009 & 0.012 & 0.009 & 0.010 & 0.014 & 0.013 \\
\hline $\mathrm{Al}_{2} \mathrm{O}_{3}$ & 0.026 & 0.030 & 0.027 & 0.024 & 0.026 & 0.022 & 0.022 & 0.030 & 0.028 & 0.032 \\
\hline $\mathrm{FeO}$ & 20.56 & 21.12 & 20.86 & 17.67 & 19.02 & 20.31 & 19.67 & 19.18 & 18.38 & 18.40 \\
\hline $\mathrm{MnO}$ & 0.246 & 0.253 & 0.247 & 0.213 & 0.232 & 0.240 & 0.236 & 0.230 & 0.219 & 0.222 \\
\hline $\mathrm{MgO}$ & 41.04 & 39.82 & 40.68 & 42.96 & 42.27 & 41.13 & 41.86 & 41.37 & 42.70 & 42.37 \\
\hline $\mathrm{CaO}$ & 0.288 & 0.312 & 0.294 & 0.292 & 0.294 & 0.287 & 0.294 & 0.289 & 0.296 & 0.291 \\
\hline $\mathrm{NiO}$ & 0.361 & 0.340 & 0.345 & 0.384 & 0.366 & 0.354 & 0.349 & 0.358 & 0.370 & 0.370 \\
\hline $\mathrm{Cr}_{2} \mathrm{O}_{3}$ & 0.036 & 0.029 & 0.031 & 0.042 & 0.044 & 0.034 & 0.036 & 0.041 & 0.039 & 0.036 \\
\hline Total & 101.37 & 100.36 & 101.44 & 101.00 & 101.84 & 101.52 & 101.91 & 100.22 & 101.41 & 100.78 \\
\hline
\end{tabular}


Table 4. (Contd.)

\begin{tabular}{|c|c|c|c|c|c|c|c|c|c|c|}
\hline Component & $4270-2$ & $4270-3$ & $4270-4$ & $4270-5$ & $4270-6$ & KhS51-1 & KhS51-4 & KhS51-5 & KhS51-6 & KhS51-7 \\
\hline \multicolumn{11}{|c|}{ Melt inclusions } \\
\hline $\mathrm{SiO}_{2}$ & 50.08 & 48.60 & 49.74 & 50.65 & 49.73 & 52.86 & 52.95 & 52.78 & 52.92 & 53.76 \\
\hline $\mathrm{TiO}_{2}$ & 2.25 & 2.57 & 2.25 & 2.28 & 2.31 & 1.71 & 1.65 & 1.76 & 1.57 & 1.58 \\
\hline $\mathrm{Al}_{2} \mathrm{O}_{3}$ & 13.11 & 12.89 & 12.72 & 12.80 & 12.85 & 13.46 & 13.29 & 13.43 & 13.11 & 12.16 \\
\hline $\mathrm{FeO}$ & 9.90 & 10.98 & 11.20 & 9.95 & 10.83 & 8.37 & 9.40 & 8.51 & 9.26 & 9.96 \\
\hline $\mathrm{MnO}$ & 0.13 & 0.14 & 0.16 & 0.15 & 0.14 & 0.12 & 0.13 & 0.11 & 0.14 & 0.14 \\
\hline $\mathrm{MgO}$ & 9.96 & 9.73 & 9.84 & 10.05 & 9.69 & 9.50 & 9.63 & 9.42 & 9.14 & 9.71 \\
\hline $\mathrm{CaO}$ & 10.62 & 10.69 & 10.42 & 10.88 & 10.57 & 9.72 & 9.76 & 9.95 & 9.89 & 9.24 \\
\hline $\mathrm{Na}_{2} \mathrm{O}$ & 2.20 & 2.20 & 2.32 & 2.19 & 2.28 & 2.41 & 2.28 & 2.37 & 2.24 & 2.24 \\
\hline $\mathrm{K}_{2} \mathrm{O}$ & 0.34 & 0.37 & 0.34 & 0.33 & 0.32 & 0.63 & 0.59 & 0.61 & 0.57 & 0.48 \\
\hline $\mathrm{P}_{2} \mathrm{O}_{5}$ & 0.20 & 0.23 & 0.18 & 0.21 & 0.22 & 0.16 & 0.15 & 0.18 & 0.15 & 0.17 \\
\hline $\mathrm{S}$, wt $\%$ & 0.04 & 0.04 & 0.05 & 0.04 & 0.03 & 0.03 & 0.04 & 0.04 & 0.03 & 0.04 \\
\hline $\mathrm{Cl}$, wt $\%$ & 0.043 & 0.032 & 0.029 & 0.039 & 0.035 & 0.003 & 0.003 & 0.005 & 0.003 & 0.003 \\
\hline Total & 98.87 & 98.47 & 99.25 & 99.57 & 99.01 & 98.98 & 99.86 & 99.17 & 99.03 & 99.48 \\
\hline $\mathrm{NiO}$ & 0.056 & 0.051 & 0.047 & 0.056 & 0.050 & 0.038 & 0.032 & 0.036 & 0.036 & 0.034 \\
\hline $\mathrm{Cr}_{2} \mathrm{O}_{3}$ & 0.093 & 0.114 & 0.046 & 0.132 & 0.150 & 0.168 & 0.099 & 0.184 & 0.204 & 0.184 \\
\hline $\mathrm{TiO}_{2}$, wt $\%$ & 2.26 & 2.72 & 2.14 & 2.24 & 2.34 & 1.65 & 1.60 & 1.74 & & \\
\hline $\mathrm{H}_{2} \mathrm{O}$, wt $\%$ & 0.12 & 0.25 & 0.13 & 0.19 & 0.14 & 0.05 & 0.06 & 0.05 & & \\
\hline $\mathrm{B}$ & 3.5 & 3.7 & 3.0 & 3.7 & 3.2 & 3.9 & 5.3 & 3.7 & & \\
\hline $\mathrm{Li}$ & 3.6 & 5.3 & 3.2 & 4.8 & 5.0 & 7.0 & 7.7 & 7.3 & & \\
\hline$\overline{\mathrm{Rb}}$ & 6.87 & 8.12 & 6.59 & 6.95 & 6.65 & 20.46 & & 19.81 & & \\
\hline $\mathrm{Ba}$ & 67.8 & 81.0 & 68.7 & 69.1 & 72.6 & 115.4 & & 114.5 & & \\
\hline Th & 0.91 & 1.02 & 0.89 & 0.89 & 0.92 & 1.38 & & 1.39 & & \\
\hline $\mathrm{U}$ & 0.27 & 0.31 & 0.26 & 0.27 & 0.25 & 0.53 & & 0.54 & & \\
\hline $\mathrm{Nb}$ & 9.15 & 11.40 & 8.66 & 9.31 & 8.92 & 8.20 & & 8.32 & & \\
\hline Та & 0.62 & 0.81 & 0.55 & 0.64 & 0.60 & 0.56 & & 0.62 & & \\
\hline $\mathrm{La}$ & 9.81 & 11.53 & 9.23 & 9.83 & 10.09 & 9.59 & & 9.62 & & \\
\hline $\mathrm{Ce}$ & 24.73 & 29.92 & 24.07 & 25.91 & 26.29 & 23.42 & & 24.17 & & \\
\hline $\mathrm{Pb}$ & 1.37 & 1.54 & 1.29 & 1.37 & 1.18 & 3.68 & & 3.47 & & \\
\hline $\operatorname{Pr}$ & 3.83 & 4.53 & 3.58 & 3.82 & 3.89 & 3.36 & & 3.58 & & \\
\hline $\mathrm{Nd}$ & 19.35 & 22.10 & 17.59 & 19.27 & 19.17 & 16.37 & & 17.89 & & \\
\hline $\mathrm{Sr}$ & 287 & 329 & 282 & 292 & 282 & 258 & & 279 & & \\
\hline Sm & 5.30 & 6.04 & 5.21 & 5.51 & 5.44 & 4.50 & & 4.65 & & \\
\hline $\mathrm{Zr}$ & 138 & 166 & 132 & 137 & 134 & 120 & & 131 & & \\
\hline $\mathrm{Hf}$ & 3.65 & 4.40 & 3.69 & 3.68 & 3.55 & 3.25 & & 3.59 & & \\
\hline $\mathrm{Eu}$ & 1.77 & 2.00 & 1.78 & 1.93 & 1.79 & 1.53 & & 1.66 & & \\
\hline $\mathrm{Ti}$ & 13508 & 16659 & 13326 & 14398 & 13649 & 10309 & & 10927 & & \\
\hline $\mathrm{Gd}$ & 6.11 & 6.73 & 5.61 & 5.93 & 6.25 & 4.80 & & 5.48 & & \\
\hline $\mathrm{Tb}$ & 0.91 & 1.02 & 0.94 & 0.96 & 0.98 & 0.81 & & 0.80 & & \\
\hline Dy & 5.47 & 6.05 & 5.81 & 5.56 & 5.46 & 4.81 & & 4.95 & & \\
\hline Ho & 0.98 & 1.10 & 1.03 & 0.98 & 1.03 & 0.84 & & 0.92 & & \\
\hline Y & 25.47 & 27.89 & 26.60 & 25.79 & 25.36 & 22.46 & & 23.75 & & \\
\hline $\mathrm{Er}$ & 2.48 & 2.87 & 2.86 & 2.66 & 2.50 & 2.21 & & 2.61 & & \\
\hline Tm & 0.34 & 0.34 & 0.34 & 0.31 & 0.33 & 0.30 & & 0.31 & & \\
\hline $\mathrm{Yb}$ & 1.96 & 2.26 & 2.34 & 2.01 & 1.94 & 1.76 & & 1.82 & & \\
\hline $\mathrm{Lu}$ & 0.27 & 0.29 & 0.26 & 0.25 & 0.28 & 0.25 & & 0.27 & & \\
\hline \multicolumn{11}{|c|}{ Host olivine } \\
\hline Fo & 80.23 & 77.60 & 77.90 & 80.32 & 78.97 & 79.93 & 79.63 & 80.17 & 79.50 & 79.15 \\
\hline $\mathrm{SiO}_{2}$ & 39.54 & 38.98 & 39.32 & 39.18 & 39.13 & 38.83 & 39.29 & 39.21 & 38.82 & 39.39 \\
\hline $\mathrm{TiO}_{2}$ & 0.014 & 0.018 & 0.013 & 0.010 & 0.010 & 0.011 & 0.008 & 0.012 & 0.013 & 0.012 \\
\hline $\mathrm{Al}_{2} \mathrm{O}_{3}$ & 0.030 & 0.028 & 0.025 & 0.025 & 0.025 & 0.023 & 0.023 & 0.024 & 0.027 & 0.027 \\
\hline $\mathrm{FeO}$ & 18.66 & 20.89 & 20.72 & 18.52 & 19.77 & 18.89 & 19.18 & 18.73 & 19.11 & 19.66 \\
\hline $\mathrm{MnO}$ & 0.223 & 0.249 & 0.249 & 0.222 & 0.237 & 0.237 & 0.240 & 0.236 & 0.243 & 0.246 \\
\hline $\mathrm{MgO}$ & 42.50 & 40.60 & 40.98 & 42.41 & 41.66 & 42.20 & 42.14 & 42.24 & 41.57 & 41.87 \\
\hline $\mathrm{CaO}$ & 0.293 & 0.304 & 0.295 & 0.297 & 0.290 & 0.266 & 0.260 & 0.270 & 0.278 & 0.267 \\
\hline $\mathrm{NiO}$ & 0.387 & 0.339 & 0.363 & 0.365 & 0.353 & 0.344 & 0.342 & 0.346 & 0.345 & 0.336 \\
\hline $\mathrm{Cr}_{2} \mathrm{O}_{3}$ & 0.045 & 0.034 & 0.039 & 0.045 & 0.040 & 0.043 & 0.039 & 0.036 & 0.037 & 0.038 \\
\hline Total & 101.72 & 101.46 & 102.02 & 101.11 & 101.54 & 100.85 & 101.53 & 101.11 & 100.46 & 101.86 \\
\hline
\end{tabular}


Table 4. (Contd.)

\begin{tabular}{|c|c|c|c|c|c|c|c|}
\hline Component & KhS51-9 & KhS51-11 & KhS51-12 & KhS51-13 & KhS51-14 & KhS51-16 & KhS51-18 \\
\hline \multicolumn{8}{|c|}{ Melt inclusions } \\
\hline $\mathrm{SiO}_{2}$ & 53.04 & 53.18 & 52.39 & 52.65 & 50.91 & 54.37 & 52.16 \\
\hline $\mathrm{TiO}_{2}$ & 1.71 & 1.79 & 1.63 & 1.54 & 1.73 & 1.46 & 1.75 \\
\hline $\mathrm{Al}_{2} \mathrm{O}_{3}$ & 13.24 & 13.22 & 12.74 & 13.73 & 12.64 & 12.94 & 13.48 \\
\hline $\mathrm{FeO}$ & 8.76 & 8.54 & 9.69 & 8.91 & 9.73 & 8.03 & 7.60 \\
\hline $\mathrm{MnO}$ & 0.12 & 0.13 & 0.12 & 0.12 & 0.12 & 0.11 & 0.12 \\
\hline $\mathrm{MgO}$ & 9.38 & 8.94 & 8.84 & 9.02 & 9.22 & 9.43 & 9.72 \\
\hline $\mathrm{CaO}$ & 10.20 & 10.41 & 10.00 & 9.47 & 9.93 & 9.82 & 10.20 \\
\hline $\mathrm{Na}_{2} \mathrm{O}$ & 2.30 & 2.30 & 2.09 & 2.85 & 2.15 & 2.28 & 2.35 \\
\hline $\mathrm{K}_{2} \mathrm{O}$ & 0.57 & 0.59 & 0.52 & 0.55 & 0.56 & 0.60 & 0.61 \\
\hline $\mathrm{P}_{2} \mathrm{O}_{5}$ & 0.16 & 0.16 & 0.16 & 0.16 & 0.18 & 0.15 & 0.15 \\
\hline $\mathrm{S}, \mathrm{wt} \%$ & 0.04 & 0.03 & 0.04 & 0.04 & 0.03 & 0.04 & 0.02 \\
\hline $\mathrm{Cl}$, wt $\%$ & 0.002 & 0.003 & 0.004 & 0.002 & 0.008 & 0.004 & 0.003 \\
\hline Total & 99.52 & 99.30 & 98.23 & 99.05 & 97.19 & 99.23 & 98.15 \\
\hline $\mathrm{NiO}$ & 0.037 & 0.032 & 0.033 & 0.031 & 0.031 & 0.044 & 0.044 \\
\hline $\mathrm{Cr}_{2} \mathrm{O}_{3}$ & 0.177 & 0.200 & 0.180 & 0.158 & 0.187 & 0.209 & 0.204 \\
\hline $\begin{array}{l}\mathrm{TiO}_{2} \text {, wt } \% \\
\mathrm{H}_{2} \mathrm{O} \text {, wt } \% \\
\mathrm{~B} \\
\mathrm{Li}\end{array}$ & & & & $\begin{array}{l}1.43 \\
0.05 \\
3.1 \\
4.1\end{array}$ & & & $\begin{array}{l}1.67 \\
0.03 \\
3.6 \\
6.6\end{array}$ \\
\hline$\overline{\mathrm{Rb}}$ & & 20.62 & & & 18.80 & & 21.94 \\
\hline $\mathrm{Ba}$ & & 115.3 & & & 110.3 & & 116.8 \\
\hline Th & & 1.42 & & & 1.41 & & 1.35 \\
\hline U & & 0.53 & & & 0.53 & & 0.58 \\
\hline $\mathrm{Nb}$ & & 8.01 & & & 8.42 & & 8.26 \\
\hline $\mathrm{Ta}$ & & 0.61 & & & 0.61 & & 0.55 \\
\hline $\mathrm{La}$ & & 9.45 & & & 9.54 & & 9.19 \\
\hline $\mathrm{Ce}$ & & 24.12 & & & 23.17 & & 23.11 \\
\hline $\mathrm{Pb}$ & & 4.12 & & & 3.46 & & 3.76 \\
\hline $\operatorname{Pr}$ & & 3.48 & & & 3.56 & & 3.28 \\
\hline $\mathrm{Nd}$ & & 16.93 & & & 16.50 & & 15.74 \\
\hline $\mathrm{Sr}$ & & 260 & & & 266 & & 258 \\
\hline $\mathrm{Sm}$ & & 4.09 & & & 4.63 & & 4.43 \\
\hline $\mathrm{Zr}$ & & 116 & & & 124 & & 119 \\
\hline Hf & & 3.39 & & & 3.27 & & 2.88 \\
\hline $\mathrm{Eu}$ & & 1.52 & & & 1.58 & & 1.56 \\
\hline $\mathrm{Ti}$ & & 10990 & & & 10838 & & 10932 \\
\hline $\mathrm{Gd}$ & & 5.00 & & & 5.25 & & 4.77 \\
\hline $\mathrm{Tb}$ & & 0.79 & & & 0.79 & & 0.75 \\
\hline Dy & & 4.66 & & & 4.92 & & 4.67 \\
\hline Ho & & 0.92 & & & 0.94 & & 0.85 \\
\hline Y & & 23.29 & & & 23.36 & & 22.97 \\
\hline $\mathrm{Er}$ & & 2.36 & & & 2.47 & & 2.30 \\
\hline $\mathrm{Tm}$ & & 0.29 & & & 0.31 & & 0.24 \\
\hline $\mathrm{Yb}$ & & 1.97 & & & 2.00 & & 1.65 \\
\hline $\mathrm{Lu}$ & & 0.28 & & & 0.27 & & 0.23 \\
\hline \multicolumn{8}{|c|}{ Host olivine } \\
\hline Fo & 80.84 & 80.26 & 79.86 & 82.14 & 78.01 & 82.23 & 80.57 \\
\hline $\mathrm{SiO}_{2}$ & 39.29 & 39.31 & 39.18 & 39.30 & 38.73 & 39.40 & 38.69 \\
\hline $\mathrm{TiO}_{2}$ & 0.008 & 0.014 & 0.011 & 0.006 & 0.013 & 0.007 & 0.010 \\
\hline $\mathrm{Al}_{2} \mathrm{O}_{3}$ & 0.024 & 0.028 & 0.029 & 0.032 & 0.022 & 0.027 & 0.030 \\
\hline $\mathrm{FeO}$ & 18.17 & 18.68 & 19.02 & 16.92 & 20.44 & 16.83 & 18.06 \\
\hline $\mathrm{MnO}$ & 0.230 & 0.236 & 0.242 & 0.213 & 0.253 & 0.215 & 0.228 \\
\hline $\mathrm{MgO}$ & 43.00 & 42.60 & 42.33 & 43.65 & 40.68 & 43.70 & 42.01 \\
\hline $\mathrm{CaO}$ & 0.265 & 0.268 & 0.267 & 0.259 & 0.277 & 0.258 & 0.268 \\
\hline $\mathrm{NiO}$ & 0.353 & 0.355 & 0.341 & 0.379 & 0.322 & 0.386 & 0.366 \\
\hline $\mathrm{Cr}_{2} \mathrm{O}_{3}$ & 0.049 & 0.043 & 0.049 & 0.059 & 0.031 & 0.058 & 0.078 \\
\hline Total & 101.41 & 101.55 & 101.49 & 100.84 & 100.78 & 100.90 & 99.75 \\
\hline
\end{tabular}

Note: The melt inclusions are $40-80 \mu \mathrm{m}$ in size. Horizontal lines separate element groups determined by different local methods (from top to bottom): ordinary electron-probe miscroanalysis, high-accuracy electron probe microanalysis, secondary ion mass spectrometry, and inductively coupled plasma mass spectrometry with laser ablation. 
Table 5. Compositions of trapped melts in olivines from the picrites of the Gudchikhinsky Formation

\begin{tabular}{|c|c|c|c|c|c|c|c|}
\hline Component & SU50-3 & SU50-5 & SU50-6 & SU50-7 & SU50-8 & SU50-9 & SU50-10 \\
\hline $\mathrm{SiO}_{2}$ & 50.33 & 50.10 & 50.02 & 49.72 & 50.19 & 50.14 & 50.43 \\
\hline $\mathrm{TiO}_{2}$ & 2.27 & 2.12 & 2.12 & 2.58 & 2.18 & 2.18 & 2.33 \\
\hline $\mathrm{Al}_{2} \mathrm{O}_{3}$ & 12.88 & 12.76 & 12.37 & 12.60 & 12.67 & 12.76 & 12.85 \\
\hline $\mathrm{Fe}_{2} \mathrm{O}_{3}$ & 0.52 & 0.53 & 0.53 & 0.53 & 0.53 & 0.53 & 0.52 \\
\hline $\mathrm{FeO}$ & 11.79 & 11.88 & 11.90 & 12.01 & 11.85 & 11.86 & 11.76 \\
\hline $\mathrm{MnO}$ & 0.12 & 0.11 & 0.11 & 0.12 & 0.11 & 0.11 & 0.12 \\
\hline $\mathrm{MgO}$ & 8.23 & 8.64 & 9.15 & 8.40 & 8.52 & 8.66 & 7.86 \\
\hline $\mathrm{CaO}$ & 10.77 & 10.76 & 10.77 & 10.95 & 10.93 & 10.66 & 11.03 \\
\hline $\mathrm{Na}_{2} \mathrm{O}$ & 2.31 & 2.34 & 2.11 & 2.22 & 2.21 & 2.30 & 2.33 \\
\hline $\mathrm{K}_{2} \mathrm{O}$ & 0.37 & 0.38 & 0.47 & 0.43 & 0.43 & 0.37 & 0.35 \\
\hline $\mathrm{P}_{2} \mathrm{O}_{5}$ & 0.21 & 0.18 & 0.22 & 0.25 & 0.18 & 0.20 & 0.21 \\
\hline $\mathrm{Cr}_{2} \mathrm{O}_{3}$ & 0.18 & 0.18 & 0.21 & 0.17 & 0.18 & 0.20 & 0.18 \\
\hline $\mathrm{NiO}$ & 0.028 & 0.031 & 0.033 & 0.028 & 0.030 & 0.031 & 0.027 \\
\hline$T_{\mathrm{cls}},{ }^{\circ} \mathrm{C}$ & 1208 & 1220 & 1231 & 1212 & 1215 & 1220 & 1197 \\
\hline Fo & 79.62 & 80.4 & 81.24 & 79.82 & 80.15 & 80.43 & 78.86 \\
\hline $\mathrm{NiO}_{O l}$ & 0.360 & 0.386 & 0.385 & 0.357 & 0.374 & 0.382 & 0.359 \\
\hline $\mathrm{K}_{\text {cor }}$ & 0.990 & 0.956 & 0.945 & 0.979 & 0.963 & 0.957 & 1.011 \\
\hline $\mathrm{S}_{\text {cor }}$ & 0.042 & 0.036 & 0.058 & 0.058 & 0.036 & 0.049 & 0.025 \\
\hline $\mathrm{Cl}_{\text {cor }}$ & 0.041 & 0.097 & 0.193 & 0.055 & 0.116 & 0.071 & 0.046 \\
\hline Component & SU50-11 & SU50-12 & SU50-13 & SU50-201 & SU50-202 & SU50-203 & SU50-204 \\
\hline $\mathrm{SiO}_{2}$ & 49.92 & 49.80 & 50.52 & 50.36 & 50.26 & 49.46 & 50.32 \\
\hline $\mathrm{TiO}_{2}$ & 2.23 & 2.25 & 2.32 & 2.38 & 2.42 & 2.31 & 2.29 \\
\hline $\mathrm{Al}_{2} \mathrm{O}_{3}$ & 12.52 & 12.70 & 13.09 & 13.15 & 13.09 & 12.70 & 12.78 \\
\hline $\mathrm{Fe}_{2} \mathrm{O}_{3}$ & 0.53 & 0.53 & 0.52 & 0.52 & 0.53 & 0.54 & 0.52 \\
\hline $\mathrm{FeO}$ & 11.93 & 11.99 & 11.73 & 11.75 & 11.83 & 12.11 & 11.79 \\
\hline $\mathrm{MnO}$ & 0.11 & 0.11 & 0.13 & 0.13 & 0.13 & 0.10 & 0.13 \\
\hline $\mathrm{MgO}$ & 9.00 & 8.72 & 7.45 & 7.11 & 7.41 & 9.25 & 8.35 \\
\hline $\mathrm{CaO}$ & 10.83 & 10.92 & 10.90 & 11.59 & 11.43 & 10.64 & 10.73 \\
\hline $\mathrm{Na}_{2} \mathrm{O}$ & 2.20 & 2.23 & 2.49 & 2.26 & 2.16 & 2.15 & 2.28 \\
\hline $\mathrm{K}_{2} \mathrm{O}$ & 0.38 & 0.37 & 0.50 & 0.35 & 0.35 & 0.36 & 0.37 \\
\hline $\mathrm{P}_{2} \mathrm{O}_{5}$ & 0.19 & 0.20 & 0.21 & 0.20 & 0.22 & 0.22 & 0.22 \\
\hline $\mathrm{Cr}_{2} \mathrm{O}_{3}$ & 0.14 & 0.15 & 0.13 & 0.19 & 0.16 & 0.15 & 0.18 \\
\hline $\mathrm{NiO}$ & 0.033 & 0.031 & 0.025 & 0.023 & 0.024 & 0.034 & 0.029 \\
\hline$T_{\mathrm{cls}},{ }^{\circ} \mathrm{C}$ & 1228 & 1221 & 1189 & 1172 & 1181 & 1234 & 1211 \\
\hline Fo & 81.01 & 80.45 & 78.06 & 77.07 & 77.66 & 81.25 & 79.85 \\
\hline $\mathrm{NiO}_{O l}$ & 0.389 & 0.381 & 0.361 & 0.340 & 0.345 & 0.384 & 0.366 \\
\hline $\mathrm{K}_{\text {cor }}$ & 0.938 & 0.957 & 1.011 & 1.032 & 1.019 & 0.953 & 0.996 \\
\hline $\mathrm{S}_{\text {cor }}$ & 0.026 & 0.035 & 0.055 & 0.040 & 0.053 & 0.055 & 0.052 \\
\hline $\mathrm{Cl}_{\text {cor }}$ & 0.070 & 0.053 & 0.134 & 0.036 & 0.040 & 0.063 & 0.046 \\
\hline
\end{tabular}


Table 5. (Contd.)

\begin{tabular}{|c|c|c|c|c|c|c|c|}
\hline Component & SU50-205 & SU50-206 & SU50-207 & SU50-208 & $4270-1$ & $4270-2$ & $4270-3$ \\
\hline $\mathrm{SiO}_{2}$ & 50.45 & 50.15 & 50.48 & 49.82 & 50.07 & 50.03 & 49.29 \\
\hline $\mathrm{TiO}_{2}$ & 2.36 & 2.36 & 2.20 & 2.23 & 2.32 & 2.25 & 2.69 \\
\hline $\mathrm{Al}_{2} \mathrm{O}_{3}$ & 12.95 & 12.77 & 12.96 & 12.73 & 12.82 & 13.08 & 13.48 \\
\hline $\mathrm{Fe}_{2} \mathrm{O}_{3}$ & 0.52 & 0.53 & 0.52 & 0.53 & 0.53 & 0.53 & 0.54 \\
\hline $\mathrm{FeO}$ & 11.75 & 11.86 & 11.75 & 11.98 & 11.88 & 11.91 & 12.16 \\
\hline $\mathrm{MnO}$ & 0.13 & 0.13 & 0.13 & 0.12 & 0.13 & 0.13 & 0.14 \\
\hline $\mathrm{MgO}$ & 7.66 & 8.08 & 8.07 & 8.82 & 8.72 & 8.62 & 7.46 \\
\hline $\mathrm{CaO}$ & 11.30 & 11.25 & 10.66 & 10.80 & 10.54 & 10.60 & 11.18 \\
\hline $\mathrm{Na}_{2} \mathrm{O}$ & 2.09 & 2.07 & 2.45 & 2.19 & 2.17 & 2.20 & 2.30 \\
\hline $\mathrm{K}_{2} \mathrm{O}$ & 0.36 & 0.36 & 0.35 & 0.32 & 0.36 & 0.34 & 0.39 \\
\hline $\mathrm{P}_{2} \mathrm{O}_{5}$ & 0.20 & 0.23 & 0.19 & 0.21 & 0.24 & 0.20 & 0.24 \\
\hline $\mathrm{Cr}_{2} \mathrm{O}_{3}$ & 0.21 & 0.19 & 0.21 & 0.23 & 0.20 & 0.09 & 0.12 \\
\hline $\mathrm{NiO}$ & 0.026 & 0.027 & 0.027 & 0.031 & 0.030 & 0.031 & 0.024 \\
\hline$T_{\mathrm{cls}},{ }^{\circ} \mathrm{C}$ & 1187 & 1199 & 1206 & 1222 & 1220 & 1218 & 1185 \\
\hline Fo & 78.3 & 79.14 & 79.36 & 80.55 & 80.41 & 80.23 & 77.6 \\
\hline $\mathrm{NiO}_{\mathrm{Ol}}$ & 0.354 & 0.349 & 0.358 & 0.370 & 0.370 & 0.387 & 0.339 \\
\hline $\mathrm{K}_{\text {cor }}$ & 1.012 & 0.999 & 0.997 & 0.964 & 0.999 & 0.998 & 1.046 \\
\hline$S_{\text {cor }}$ & 0.029 & 0.061 & 0.036 & 0.018 & 0.039 & 0.038 & 0.037 \\
\hline $\mathrm{Cl}_{\text {cor }}$ & 0.044 & 0.043 & 0.066 & 0.042 & 0.041 & 0.042 & 0.033 \\
\hline Component & $4270-4$ & $4270-5$ & $4270-6$ & KhS51-1 & KhS51-4 & KhS51-5 & KhS51-6 \\
\hline $\mathrm{SiO}_{2}$ & 50.33 & 50.26 & 50.02 & 52.43 & 52.57 & 52.18 & 52.87 \\
\hline $\mathrm{TiO}_{2}$ & 2.37 & 2.26 & 2.37 & 1.68 & 1.65 & 1.72 & 1.57 \\
\hline $\mathrm{Al}_{2} \mathrm{O}_{3}$ & 13.37 & 12.70 & 13.16 & 13.25 & 13.30 & 13.11 & 13.13 \\
\hline $\mathrm{Fe}_{2} \mathrm{O}_{3}$ & 0.52 & 0.53 & 0.53 & 0.49 & 0.49 & 0.50 & 0.48 \\
\hline $\mathrm{FeO}$ & 11.79 & 11.83 & 11.91 & 11.05 & 11.01 & 11.14 & 10.89 \\
\hline $\mathrm{MnO}$ & 0.16 & 0.14 & 0.14 & 0.12 & 0.14 & 0.12 & 0.13 \\
\hline $\mathrm{MgO}$ & 7.43 & 8.63 & 7.98 & 8.06 & 7.92 & 8.24 & 7.83 \\
\hline $\mathrm{CaO}$ & 10.96 & 10.79 & 10.83 & 9.57 & 9.77 & 9.71 & 9.91 \\
\hline $\mathrm{Na}_{2} \mathrm{O}$ & 2.44 & 2.17 & 2.34 & 2.37 & 2.28 & 2.31 & 2.24 \\
\hline $\mathrm{K}_{2} \mathrm{O}$ & 0.36 & 0.33 & 0.33 & 0.62 & 0.59 & 0.60 & 0.57 \\
\hline $\mathrm{P}_{2} \mathrm{O}_{5}$ & 0.19 & 0.21 & 0.23 & 0.16 & 0.15 & 0.18 & 0.15 \\
\hline $\mathrm{Cr}_{2} \mathrm{O}_{3}$ & 0.05 & 0.13 & 0.15 & 0.17 & 0.10 & 0.18 & 0.20 \\
\hline $\mathrm{NiO}$ & 0.026 & 0.030 & 0.027 & 0.026 & 0.025 & 0.027 & 0.025 \\
\hline$T_{\mathrm{cls}},{ }^{\circ} \mathrm{C}$ & 1187 & 1217 & 1201 & 1213 & 1207 & 1216 & 1203 \\
\hline Fo & 77.9 & 80.32 & 78.97 & 79.93 & 79.63 & 80.17 & 79.5 \\
\hline $\mathrm{NiO}_{O l}$ & 0.363 & 0.365 & 0.353 & 0.344 & 0.342 & 0.346 & 0.345 \\
\hline $\mathrm{K}_{\text {cor }}$ & 1.051 & 0.992 & 1.024 & 0.984 & 1.001 & 0.976 & 1.002 \\
\hline $\mathrm{S}_{\text {cor }}$ & 0.049 & 0.036 & 0.032 & 0.027 & 0.040 & 0.039 & 0.035 \\
\hline $\mathrm{Cl}_{\text {cor }}$ & 0.030 & 0.039 & 0.036 & 0.003 & 0.003 & 0.005 & 0.003 \\
\hline
\end{tabular}


Table 5. (Contd.)

\begin{tabular}{|c|c|c|c|c|c|c|c|c|}
\hline Component & KhS51-9 & KhS51-11 & KhS51-12 & KhS51-13 & KhS51-14 & KhS51-16 & KhS51-17 & KhS51-18 \\
\hline $\mathrm{SiO}_{2}$ & 52.23 & 52.37 & 52.85 & 51.75 & 52.20 & 53.34 & 53.20 & 51.68 \\
\hline $\mathrm{TiO}_{2}$ & 1.65 & 1.73 & 1.64 & 1.45 & 1.82 & 1.39 & 1.64 & 1.69 \\
\hline $\mathrm{Al}_{2} \mathrm{O}_{3}$ & 12.81 & 12.74 & 12.85 & 12.95 & 13.26 & 12.30 & 12.72 & 13.05 \\
\hline $\mathrm{Fe}_{2} \mathrm{O}_{3}$ & 0.49 & 0.49 & 0.49 & 0.51 & 0.50 & 0.48 & 0.48 & 0.50 \\
\hline $\mathrm{FeO}$ & 11.12 & 11.08 & 10.91 & 11.36 & 11.13 & 10.73 & 10.78 & 11.32 \\
\hline $\mathrm{MnO}$ & 0.12 & 0.13 & 0.14 & 0.13 & 0.15 & 0.11 & 0.14 & 0.11 \\
\hline $\mathrm{MgO}$ & 8.59 & 8.27 & 8.03 & 9.39 & 7.29 & 9.20 & 8.05 & 8.53 \\
\hline $\mathrm{CaO}$ & 9.87 & 10.04 & 10.09 & 8.93 & 10.42 & 9.34 & 9.79 & 9.87 \\
\hline $\mathrm{Na}_{2} \mathrm{O}$ & 2.22 & 2.22 & 2.11 & 2.69 & 2.26 & 2.17 & 2.22 & 2.28 \\
\hline $\mathrm{K}_{2} \mathrm{O}$ & 0.55 & 0.57 & 0.53 & 0.52 & 0.59 & 0.57 & 0.56 & 0.59 \\
\hline $\mathrm{P}_{2} \mathrm{O}_{5}$ & 0.16 & 0.15 & 0.16 & 0.15 & 0.19 & 0.14 & 0.19 & 0.15 \\
\hline $\mathrm{Cr}_{2} \mathrm{O}_{3}$ & 0.17 & 0.19 & 0.18 & 0.15 & 0.20 & 0.20 & 0.21 & 0.20 \\
\hline $\mathrm{NiO}$ & 0.028 & 0.027 & 0.025 & 0.033 & 0.022 & 0.033 & 0.026 & 0.029 \\
\hline$T_{\text {cls }},{ }^{\circ} \mathrm{C}$ & 1223 & 1214 & 1206 & 1253 & 1185 & 1241 & 1209 & 1222 \\
\hline Fo & 80.84 & 80.26 & 79.86 & 82.14 & 78.01 & 82.23 & 80.07 & 80.57 \\
\hline $\mathrm{NiO}_{O l}$ & 0.353 & 0.355 & 0.341 & 0.379 & 0.322 & 0.386 & 0.354 & 0.366 \\
\hline$\overline{\mathrm{K}_{\text {cor }}}$ & 0.967 & 0.964 & 1.008 & 0.943 & 1.049 & 0.951 & 1.017 & 0.968 \\
\hline $\mathrm{S}_{\text {cor }}$ & 0.038 & 0.032 & 0.041 & 0.038 & 0.032 & 0.035 & 0.051 & 0.021 \\
\hline $\mathrm{Cl}_{\text {cor }}$ & 0.002 & 0.003 & 0.004 & 0.002 & 0.008 & 0.004 & 0.003 & 0.003 \\
\hline
\end{tabular}

Note: $T_{\text {cls }}, C$ is the temperature of equilibrium with the host olivine. $F o(\mathrm{~mol} \%)$ and $\mathrm{NiO}(\mathrm{wt} \%)$ are the compositional characteristics of the host olivine. $\mathrm{K}_{\text {cor }}$ is the correction factor for incompatible elements (see text for explanation). $\mathrm{S}_{\mathrm{cor}}$ and $\mathrm{Cl}_{\text {cor }}$ are the corrected contents of sulfur and chlorine in the melt.

\section{Conditions of Primary Magma Formation}

Given the composition of primary melts, the conditions of their equilibrium (pressure and temperature) with the mantle source can be estimated. Such calculations are usually performed assuming an olivine-bearing (peridotitic) source (Herzberg and O'Hara, 2002). However, the compositions of olivine phenocrysts from the Gudchikhinsky picrites indicate the absence of olivine in their mantle source (see above and Sobolev et al., 2007). Indeed, the determination of liquidus assemblage for the estimated primary melts using the olivine-melt (Ford et al., 1983) and clinopyroxenemelt (Danyushevsky et al., 1996) models and the Petrolog software (Danyushevsky, 2001) showed that the melts become olivine-undersaturated and have clinopyroxene as a liquidus phase at pressures above 1.2$1.8 \mathrm{GPa}$. However, the clinopyroxene-melt equilibrium model of Danyushevsky et al. (1996) was calibrated at low pressures and its application requires additional testing. Figure 12a presents the results of such testing, which revealed a systematic overestimation of calculated equilibrium temperature compared with experi- mental values. The temperature correction shows a significant correlation with pressure and can be readily applied to adjust the $P-T$ liquidus parameters of primary melts. The corrected data show that the temperature of clinopyroxene liquidus for the estimated primary melts becomes significantly lower than the dry solidus of mantle peridotite at pressures higher than $3 \mathrm{GPa}$, but remains above the "dry" pyroxenite solidus (Fig. 12b). This suggests that the primary trap melts could be derived from a pyroxenite at great depths, while almost no melting occurred in a "dry" peridotite. It should be noted that small amounts of $\mathrm{CO}_{2}$ and $\mathrm{H}_{2} \mathrm{O}$ in natural mantle peridotites may promote low-degree partial melting at low temperatures and high pressures. This process produces undersaturated alkaline melts enriched in incompatible elements similar to meymechites or alkaline and subalkaline picrites (Sobolev et al., 1991; Ryabchikov, 2003). Therefore, it is no surprise that such melts occur in the province. However, the volume of such magmatism is significantly limited, especially within the Noril'sk region. 

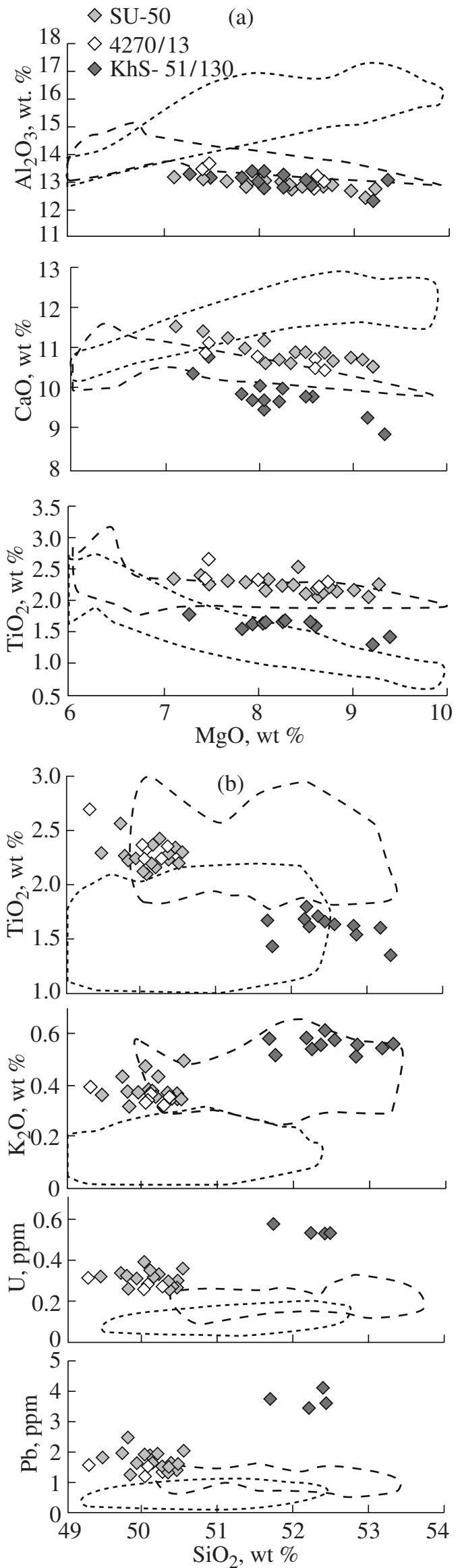

Fig. 7. Diagram of the compositions of trapped melts in olivine phenocrysts from the Gudchikhinsky picrites.

All compositions were recalculated to equilibrium with the host olivine (see text). The dotted line encloses the compositional field of glasses from mid-ocean ridge basalts according to the PetDB database (http://www.petdb.org/ petdbWeb/index.jsp); and the dashed line encloses the field of glass compositions from Mauna Loa Volcano, Hawaii according to the GEOROC database (http://georoc.mpchmainz.gwdg.de/georoc/).

\section{DISCUSSION}

\section{Potential Mantle Temperature}

Assuming that the lithosphere of the Siberian craton is no less than $130 \mathrm{~km}$ thick (Artemieva and Mooney, 2001), the minimum temperature of formation of the Gudchikhinsky primary magmas at a pressure of $4 \mathrm{GPa}$ can be estimated as $1540^{\circ} \mathrm{C}$ (Fig. 12b). Taking into account a mantle adiabatic gradient of $10^{\circ} \mathrm{C} / \mathrm{GPa}$, these conditions correspond to the minimum potential mantle temperature of $\sim 1500^{\circ} \mathrm{C}$ (McKenzie and Bickle, 1988). The maximum temperature is constrained by the intersection of the liquidus of the primary Gudchikhinsky magmas with the pyroxenite solidus at $P=5.5 \mathrm{GPa}$ and $T=1635^{\circ} \mathrm{C}$ (Fig. 12b). The obtained maximum potential temperature is approximately $1580^{\circ} \mathrm{C}$. These results are similar but slightly lower than the potential temperatures of the mantle sources of the Siberian trap province $\left(1630-1660^{\circ} \mathrm{C}\right)$ estimated for the subalkaline and tholeiitic magmas of the Putorana Plateau and the alkali picrites and meymechites of the MaimechaKotui province (Ryabchikov, 2003).

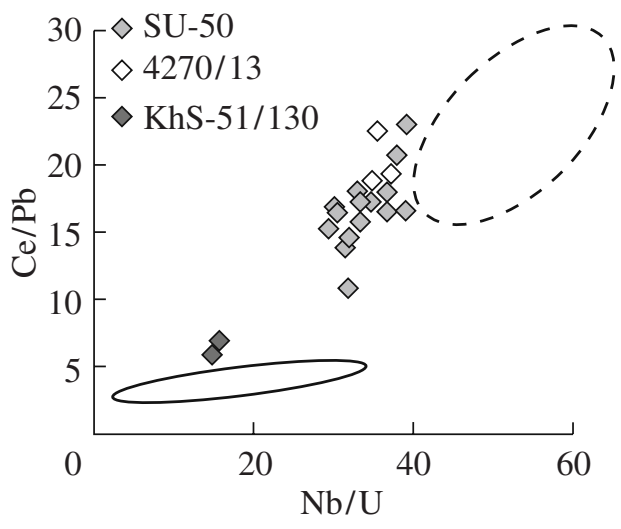

Fig. 8. Indicator trace element ratios in melt inclusions in olivine from the Gudchikhinsky picrites.

The dashed line encloses the field of basalt compositions from ocean islands according to Hofmann (2002) and GEOROC database (http://georoc.mpch-mainz.gwdg.de/ georoc/). The solid line encloses the compositional field of the crystalline rocks of the continental crust (Rudnick, 2002). 


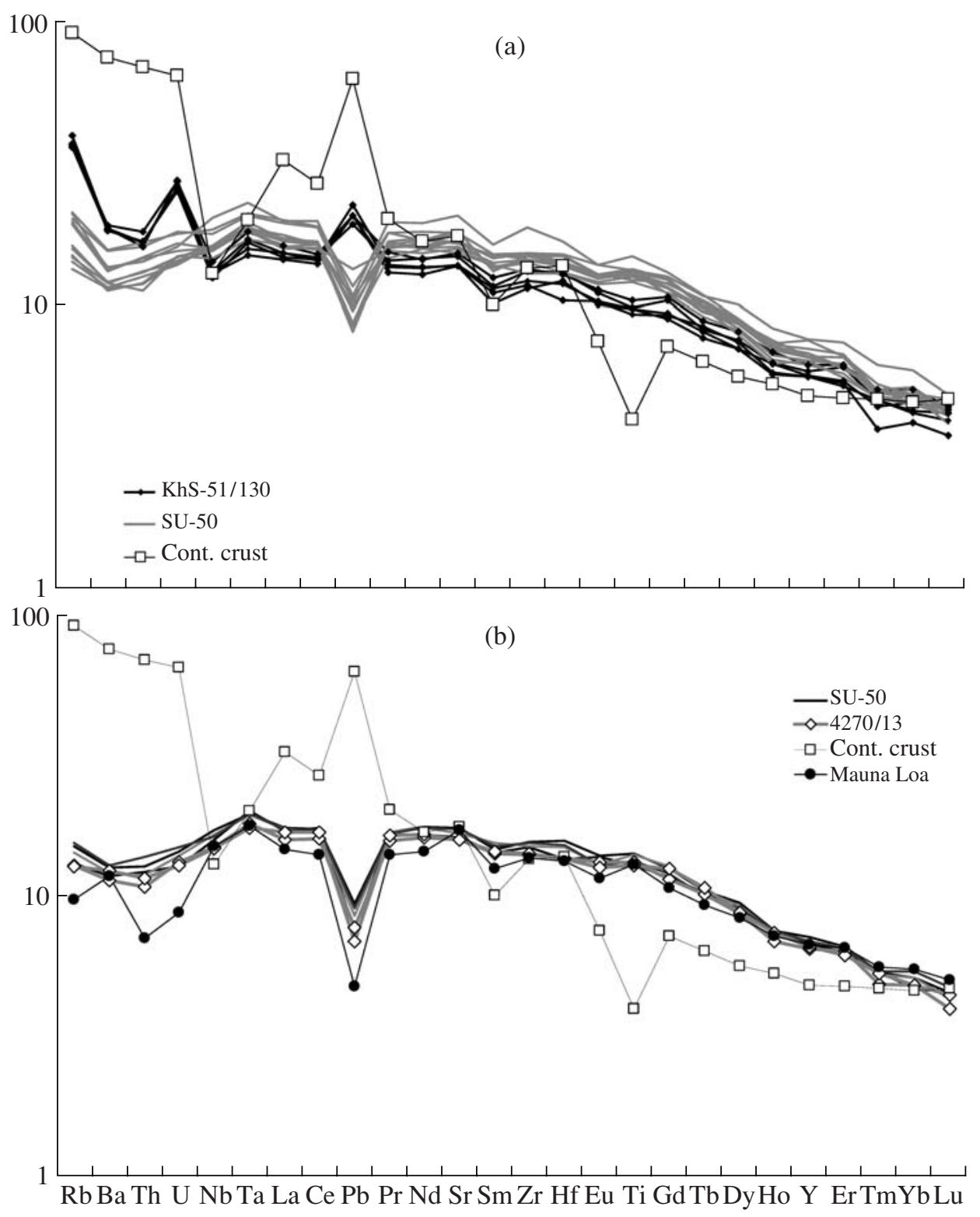

Fig. 9. Distribution patterns of incompatible lithophile elements in melt inclusions in olivine from the Gudchikhinsky picrites. (a) Compositions of contaminated melts. (b) Compositions of weakly contaminated or uncontaminated melts. Cont. crust is the average composition of continental crust (Rudnick, 2002). Also shown is the average composition of melt inclusions in olivine from Mauna Loa Volcano, Hawaii (Sobolev et al., 2005 and unpublished data). All contents are normalized to the primitive mantle composition (Hofmann, 1988).

\section{Was There a Mantle Plume?}

Compared with the convecting upper mantle with temperatures of up to $1350^{\circ} \mathrm{C}$ (White and McKenzie, 1995; Herzberg and O'Hara, 2002), the estimated magmas are overheated by $150-230^{\circ} \mathrm{C}$. This is direct evidence for the plume-related origin of the Siberian LIP and is consistent with the conclusions of some previous studies (Sobolev et al., 1991; Wooden et al., 1993; Lightfoot et al., 1993; Ryabchikov, 2003). According to the data obtained here, the mantle plume that produced the Siberian trap province had a potential temperature of about $1500-1580^{\circ} \mathrm{C}$, which is similar to the temperature of the Hawaiian mantle plume $\left(1500-1600^{\circ} \mathrm{C}\right.$; Sobolev et al., 2005). The participation of a mantle plume in the formation of the Siberian trap magmatism is also independently supported by the composition of uncontaminated Gudchikhinsky melts (Fig. 9b). Their characteristics, including the ${ }^{143} \mathrm{Nd} /{ }^{144} \mathrm{Nd}$ and ${ }^{87} \mathrm{Sr} /{ }^{86} \mathrm{Sr}$ isotopic ratios, are similar to those of the classic Hawaiian mantle plume (Wooden et al., 1993). 

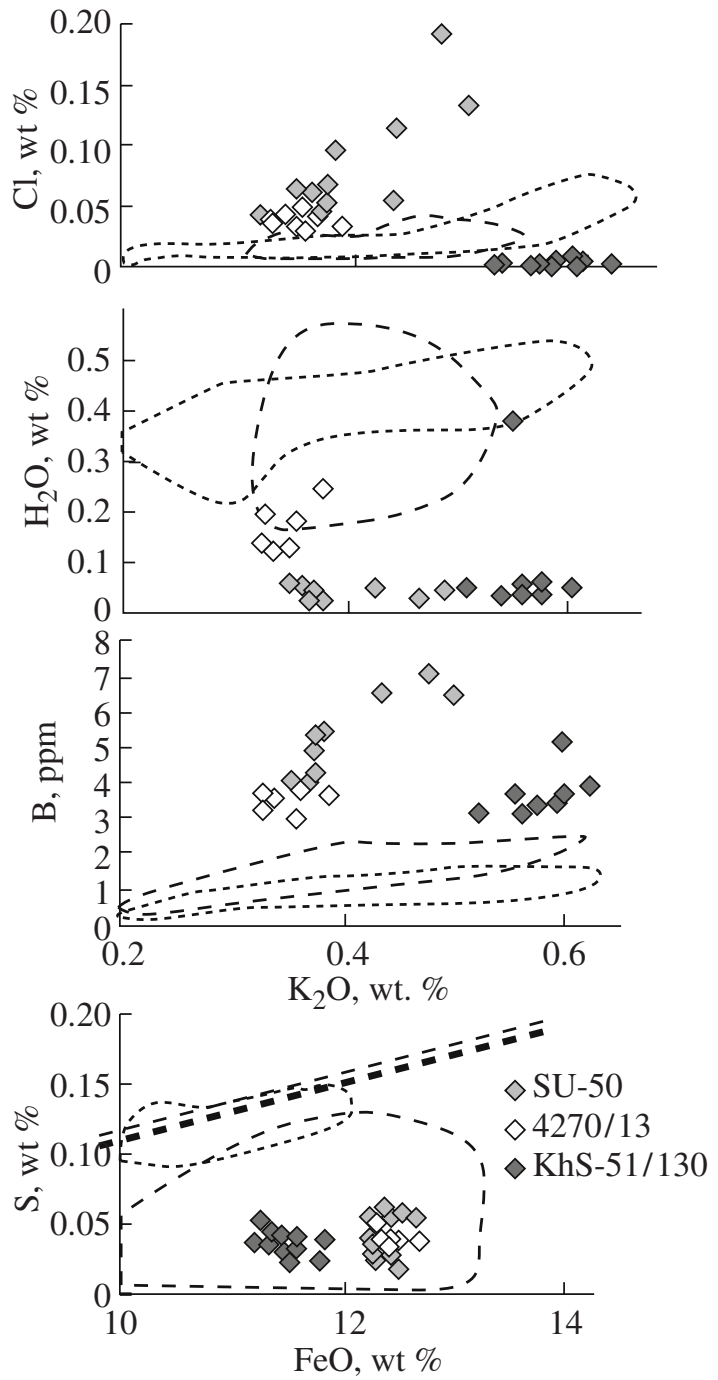

Fig. 10. Contents of volatile components in melts trapped in olivine phenocrysts from the Gudchikhinsky picrites.

The dashed line encloses the field of glasses from Mauna Loa Volcano, Hawaii according to the GEOROC database (http://georoc.mpch-mainz.gwdg.de/georoc/), and the dotted line encloses the field of glasses from mid-ocean ridge basalts without evidence for seawater contamination according to the PetDB database (http://www.petdb. org/petdbWeb/index.jsp). The fields of glasses in the $\mathrm{K}_{2} \mathrm{O}$ $\mathrm{B}$ coordinates are shown according to the unpublished data of A.V. Sobolev from the investigation of melt inclusions in olivine. The double dashed line encloses the region of sulfur saturation according to the data of Mathez (1976).

\section{Mantle Source Composition}

A striking feature of the LIP studied (Sobolev et al., 2007 ) is wide variations in the contribution of reaction pyroxenite to primary melts within particular provinces (Fig. 13). The detailed investigation of picrites from the Noril'sk region showed that this characteristic varied with time in the Siberian trap province (Figs. 2, 5). The initial stage of the development of this province (Gudchikhinsky Formation) involved melting of an almost

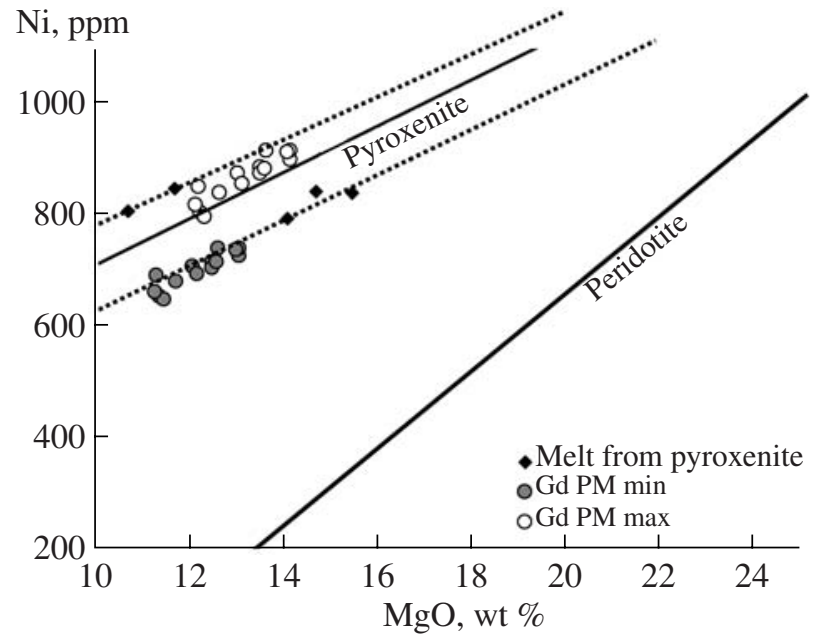

Fig. 11. Variations in $\mathrm{MgO}$ and $\mathrm{Ni}$ contents in the primary magmas of the Gudchikhinsky Formation (gray circles).

The dashed lines enclose the compositional fields of melts derived from olivine-free pyroxenites. The solid lines show the calculated compositions of melts from pyroxenite and peridotite sources according to the data of Sobolev et al. (2005). Experimental data on $\mathrm{MgO}$ and $\mathrm{Ni}$ contents in melts derived from pyroxenite (black diamonds) are shown after Sobolev et al. (2007). Gd PM max and Gd PM min are the calculated compositions of primary melts of the Gudchikhinsky Formation corresponding to the upper and lower boundary of the compositional field of pyroxenite-derived melts, respectively.

pure pyroxenite component. The contribution of a pyroxenite source decreased in the melts that formed the rocks of later formations (40 wt \% for the Tuklonsky Formation and $60 \mathrm{wt} \%$ for the Nadezhdinsky Formation).

It should be noted that the calculated contributions of the pyroxenite component to the melts of the Tuklonsky and Nadezhdinsky formations should be considered as maximum estimates because of the possible influence of magma fractionation, which is indicated by the iron-rich compositions of olivine from these rocks (the most magnesian olivine is $\mathrm{Fo}_{80}$ ). The fractionation of clinopyroxene and olivine could result in the underestimation of the $\mathrm{Mn} / \mathrm{Fe}$ ratio and overestimation of the $\mathrm{Ni} /(\mathrm{Mg} / \mathrm{Fe})$ ratio in olivine; consequently, the role of the pyroxenite component could be overestimated (Sobolev et al., 2007, 2008). This warning is not important for the rocks of the Gudchikhinsky Formation, which contain magnesian olivine and for which the suggestion of a pure pyroxenite source seems to be plausible.

Thus, it can be concluded that the beginning of the formation of the Siberian LIP was directly related to the presence of recycled crust in the mantle source. This can be explained by the lower melting temperature of recycled material compared with that of peridotite (Fig. 14a). Assume that two identical Hawaiian-type mantle plumes with identical potential temperatures of 
Table 6. Compositions of the primary melts of the Gudchikhinsky Formation

\begin{tabular}{|c|c|c|c|c|c|c|c|}
\hline Component & SU-50-3 & SU50-10 & SU50-201 & SU50-202 & SU50-204 & SU50-205 & SU50-206 \\
\hline \multicolumn{8}{|c|}{ PM min } \\
\hline $\mathrm{SiO}_{2}$ & 48.93 & 49.02 & 48.93 & 48.92 & 48.96 & 49.07 & 48.69 \\
\hline $\mathrm{TiO}_{2}$ & 1.99 & 2.04 & 2.09 & 2.14 & 2.02 & 2.08 & 2.05 \\
\hline $\mathrm{Al}_{2} \mathrm{O}_{3}$ & 11.30 & 11.30 & 11.56 & 11.59 & 11.26 & 11.43 & 11.11 \\
\hline $\mathrm{Fe}_{2} \mathrm{O}_{3}$ & 0.54 & 0.54 & 0.55 & 0.55 & 0.54 & 0.54 & 0.55 \\
\hline $\mathrm{FeO}$ & 12.20 & 12.24 & 12.36 & 12.37 & 12.18 & 12.26 & 12.31 \\
\hline $\mathrm{MnO}$ & 0.11 & 0.11 & 0.12 & 0.12 & 0.11 & 0.11 & 0.12 \\
\hline $\mathrm{MgO}$ & 12.48 & 12.05 & 11.29 & 11.34 & 12.48 & 11.70 & 12.61 \\
\hline $\mathrm{CaO}$ & 9.45 & 9.70 & 10.18 & 10.12 & 9.45 & 9.98 & 9.79 \\
\hline $\mathrm{Na}_{2} \mathrm{O}$ & 2.02 & 2.04 & 1.99 & 1.91 & 2.01 & 1.85 & 1.80 \\
\hline $\mathrm{K}_{2} \mathrm{O}$ & 0.32 & 0.31 & 0.31 & 0.31 & 0.33 & 0.32 & 0.31 \\
\hline $\mathrm{P}_{2} \mathrm{O}_{5}$ & 0.18 & 0.19 & 0.17 & 0.20 & 0.19 & 0.18 & 0.20 \\
\hline $\mathrm{Cr}_{2} \mathrm{O}_{3}$ & 0.16 & 0.16 & 0.16 & 0.14 & 0.16 & 0.18 & 0.16 \\
\hline $\mathrm{H}_{2} \mathrm{O}$ & 0.21 & 0.21 & 0.20 & 0.20 & 0.21 & 0.21 & 0.21 \\
\hline $\mathrm{S}, \mathrm{ppm}$ & 372 & 222 & 349 & 467 & 454 & 256 & 535 \\
\hline $\mathrm{Cl}, \mathrm{ppm}$ & 356 & 409 & 315 & 355 & 410 & 387 & 374 \\
\hline $\mathrm{Ni}, \mathrm{ppm}$ & 717 & 709 & 694 & 655 & 708 & 682 & 742 \\
\hline$T,{ }^{\circ} \mathrm{C}$ & 1270 & 1261 & 1242 & 1242 & 1269 & 1249 & 1269 \\
\hline $\log f_{\mathrm{O}_{2}}$ & -9.4 & -9.5 & -9.7 & -9.7 & -9.4 & -9.6 & -9.4 \\
\hline dNNO & -2.5 & -2.6 & -2.6 & -2.6 & -2.5 & -2.6 & -2.5 \\
\hline Fo, mol \% & 85.5 & 85 & 84 & 84 & 85.5 & 84.5 & 85.5 \\
\hline $\mathrm{NiO}_{O l}$ & 0.75 & 0.78 & 0.81 & 0.76 & 0.74 & 0.77 & 0.77 \\
\hline$O l, \%$ & 12.0 & 11.9 & 11.9 & 11.2 & 11.7 & 11.5 & 12.8 \\
\hline \multicolumn{8}{|c|}{$\mathrm{PM} \max$} \\
\hline $\mathrm{SiO}_{2}$ & 48.65 & 48.76 & 48.69 & 48.68 & 48.68 & 48.82 & 48.42 \\
\hline $\mathrm{TiO}_{2}$ & 1.93 & 1.99 & 2.03 & 2.08 & 1.96 & 2.02 & 1.99 \\
\hline $\mathrm{Al}_{2} \mathrm{O}_{3}$ & 10.96 & 10.97 & 11.25 & 11.28 & 10.91 & 11.12 & 10.77 \\
\hline $\mathrm{Fe}_{2} \mathrm{O}_{3}$ & 0.54 & 0.55 & 0.55 & 0.55 & 0.54 & 0.55 & 0.55 \\
\hline $\mathrm{FeO}$ & 12.22 & 12.27 & 12.40 & 12.42 & 12.20 & 12.29 & 12.33 \\
\hline $\mathrm{MnO}$ & 0.10 & 0.11 & 0.11 & 0.11 & 0.11 & 0.11 & 0.11 \\
\hline $\mathrm{MgO}$ & 13.51 & 13.02 & 12.17 & 12.22 & 13.50 & 12.62 & 13.63 \\
\hline $\mathrm{CaO}$ & 9.16 & 9.42 & 9.92 & 9.85 & 9.16 & 9.70 & 9.49 \\
\hline $\mathrm{Na}_{2} \mathrm{O}$ & 1.96 & 1.99 & 1.94 & 1.86 & 1.95 & 1.80 & 1.74 \\
\hline $\mathrm{K}_{2} \mathrm{O}$ & 0.31 & 0.30 & 0.30 & 0.30 & 0.32 & 0.31 & 0.30 \\
\hline $\mathrm{P}_{2} \mathrm{O}_{5}$ & 0.18 & 0.18 & 0.17 & 0.19 & 0.19 & 0.17 & 0.19 \\
\hline $\mathrm{Cr}_{2} \mathrm{O}_{3}$ & 0.16 & 0.16 & 0.16 & 0.14 & 0.16 & 0.18 & 0.16 \\
\hline $\mathrm{H}_{2} \mathrm{O}$ & 0.21 & 0.20 & 0.20 & 0.20 & 0.21 & 0.21 & 0.20 \\
\hline $\mathrm{S}, \mathrm{ppm}$ & 361 & 216 & 340 & 455 & 440 & 249 & 518 \\
\hline $\mathrm{Cl}, \mathrm{ppm}$ & 345 & 397 & 306 & 346 & 397 & 376 & 362 \\
\hline $\mathrm{Ni}, \mathrm{ppm}$ & 887 & 877 & 853 & 806 & 875 & 840 & 917 \\
\hline$T,{ }^{\circ} \mathrm{C}$ & 1292 & 1282 & 1262 & 1262 & 1291 & 1270 & 1291 \\
\hline $\log f_{\mathrm{O}_{2}}$ & -9.1 & -9.2 & -9.5 & -9.4 & -9.1 & -9.4 & -9.1 \\
\hline dNNO & -2.5 & -2.6 & -2.6 & -2.6 & -2.5 & -2.5 & -2.5 \\
\hline Fo, mol \% & 86.5 & 86 & 85 & 85 & 86.5 & 85.5 & 86.5 \\
\hline $\mathrm{NiO}_{O l}$ & 0.85 & 0.87 & 0.92 & 0.86 & 0.83 & 0.87 & 0.86 \\
\hline$O l, \%$ & 14.7 & 14.4 & 14.2 & 13.6 & 14.4 & 13.9 & 15.5 \\
\hline
\end{tabular}


Table 6. (Contd.)

\begin{tabular}{|c|c|c|c|c|c|c|c|c|c|}
\hline Component & SU50-208 & $4270-1$ & $4270-2$ & $4270-3$ & $4270-4$ & $4270-5$ & $4270-6$ & Average & $\begin{array}{l}\text { Standard } \\
\text { deviation }\end{array}$ \\
\hline \multicolumn{10}{|c|}{ PM min } \\
\hline $\mathrm{SiO}_{2}$ & 48.51 & 48.69 & 48.76 & 48.04 & 49.03 & 48.86 & 48.68 & 48.79 & 0.26 \\
\hline $\mathrm{TiO}_{2}$ & 1.95 & 2.03 & 1.99 & 2.38 & 2.10 & 1.98 & 2.08 & 2.07 & 0.10 \\
\hline $\mathrm{Al}_{2} \mathrm{O}_{3}$ & 11.18 & 11.23 & 11.59 & 11.92 & 11.89 & 11.11 & 11.58 & 11.43 & 0.25 \\
\hline $\mathrm{Fe}_{2} \mathrm{O}_{3}$ & 0.55 & 0.54 & 0.54 & 0.56 & 0.55 & 0.54 & 0.55 & 0.55 & 0.01 \\
\hline $\mathrm{FeO}$ & 12.31 & 12.23 & 12.26 & 12.67 & 12.31 & 12.19 & 12.36 & 12.30 & 0.12 \\
\hline $\mathrm{MnO}$ & 0.11 & 0.11 & 0.12 & 0.12 & 0.14 & 0.12 & 0.13 & 0.12 & 0.01 \\
\hline $\mathrm{MgO}$ & 13.05 & 13.04 & 12.55 & 11.43 & 11.24 & 13.00 & 12.14 & 12.17 & 0.63 \\
\hline $\mathrm{CaO}$ & 9.48 & 9.22 & 9.39 & 9.88 & 9.74 & 9.44 & 9.53 & 9.67 & 0.28 \\
\hline $\mathrm{Na}_{2} \mathrm{O}$ & 1.92 & 1.90 & 1.94 & 2.03 & 2.17 & 1.90 & 2.06 & 1.97 & 0.09 \\
\hline $\mathrm{K}_{2} \mathrm{O}$ & 0.28 & 0.32 & 0.30 & 0.34 & 0.32 & 0.29 & 0.29 & 0.31 & 0.02 \\
\hline $\mathrm{P}_{2} \mathrm{O}_{5}$ & 0.19 & 0.21 & 0.18 & 0.21 & 0.17 & 0.18 & 0.20 & 0.19 & 0.01 \\
\hline $\mathrm{Cr}_{2} \mathrm{O}_{3}$ & 0.20 & 0.17 & 0.08 & 0.11 & 0.04 & 0.11 & 0.14 & 0.14 & 0.04 \\
\hline $\mathrm{H}_{2} \mathrm{O}$ & 0.18 & 0.21 & 0.20 & 0.23 & 0.21 & 0.19 & 0.19 & 0.20 & 0.01 \\
\hline $\mathrm{S}, \mathrm{ppm}$ & 157 & 337 & 339 & 329 & 437 & 319 & 286 & 347 & 95 \\
\hline $\mathrm{Cl}, \mathrm{ppm}$ & 372 & 358 & 376 & 296 & 268 & 339 & 318 & 352 & 38 \\
\hline $\mathrm{Ni}, \mathrm{ppm}$ & 728 & 742 & 716 & 651 & 665 & 739 & 695 & 703 & 29 \\
\hline$T,{ }^{\circ} \mathrm{C}$ & 1282 & 1280 & 1271 & 1245 & 1244 & 1280 & 1263 & 1262 & 14 \\
\hline $\log f_{\mathrm{O}_{2}}$ & -9.2 & -9.2 & -9.3 & -9.6 & -9.7 & -9.2 & -9.4 & -9.4 & 0.2 \\
\hline dNNO & -2.5 & -2.5 & -2.5 & -2.6 & -2.6 & -2.5 & -2.5 & -2.5 & $\mathbf{0}$ \\
\hline Fo, mol \% & 86 & 86 & 85.5 & 84 & 84 & 86 & 85 & 85.0 & 0.8 \\
\hline $\mathrm{NiO}_{O l}$ & 0.72 & 0.74 & 0.75 & 0.75 & 0.79 & 0.74 & 0.75 & 0.76 & 0.02 \\
\hline$O l, \%$ & 12.0 & 12.2 & 11.2 & 11.4 & 10.9 & 12.3 & 11.8 & 11.8 & 0.5 \\
\hline \multicolumn{10}{|c|}{ PM max } \\
\hline $\mathrm{SiO}_{2}$ & 48.23 & 48.41 & 48.50 & 47.82 & 48.79 & 48.57 & 48.43 & 48.53 & 0.25 \\
\hline $\mathrm{TiO}_{2}$ & 1.89 & 1.96 & 1.93 & 2.31 & 2.05 & 1.91 & 2.02 & 2.01 & 0.10 \\
\hline $\mathrm{Al}_{2} \mathrm{O}_{3}$ & 10.81 & 10.86 & 11.23 & 11.60 & 11.58 & 10.74 & 11.25 & 11.10 & 0.27 \\
\hline $\mathrm{Fe}_{2} \mathrm{O}_{3}$ & 0.55 & 0.54 & 0.55 & 0.56 & 0.55 & 0.54 & 0.55 & 0.55 & 0.01 \\
\hline $\mathrm{FeO}$ & 12.31 & 12.23 & 12.27 & 12.70 & 12.36 & 12.20 & 12.38 & 12.33 & 0.13 \\
\hline $\mathrm{MnO}$ & 0.10 & 0.11 & 0.11 & 0.12 & 0.14 & 0.12 & 0.12 & 0.11 & 0.01 \\
\hline $\mathrm{MgO}$ & 14.14 & 14.13 & 13.58 & 12.31 & 12.11 & 14.08 & 13.11 & 13.15 & 0.71 \\
\hline $\mathrm{CaO}$ & 9.17 & 8.92 & 9.10 & 9.62 & 9.49 & 9.13 & 9.25 & 9.39 & 0.29 \\
\hline $\mathrm{Na}_{2} \mathrm{O}$ & 1.86 & 1.83 & 1.88 & 1.98 & 2.11 & 1.84 & 2.00 & 1.91 & 0.09 \\
\hline $\mathrm{K}_{2} \mathrm{O}$ & 0.27 & 0.30 & 0.29 & 0.33 & 0.31 & 0.28 & 0.28 & 0.30 & 0.02 \\
\hline $\mathrm{P}_{2} \mathrm{O}_{5}$ & 0.18 & 0.20 & 0.17 & 0.21 & 0.16 & 0.18 & 0.19 & 0.18 & 0.01 \\
\hline $\mathrm{Cr}_{2} \mathrm{O}_{3}$ & 0.19 & 0.17 & 0.08 & 0.10 & 0.04 & 0.11 & 0.13 & 0.14 & 0.04 \\
\hline $\mathrm{H}_{2} \mathrm{O}$ & 0.18 & 0.20 & 0.19 & 0.22 & 0.20 & 0.18 & 0.19 & 0.20 & 0.01 \\
\hline $\mathrm{S}, \mathrm{ppm}$ & 152 & 326 & 329 & 321 & 425 & 308 & 277 & 337 & 93 \\
\hline $\mathrm{Cl}, \mathrm{ppm}$ & 360 & 347 & 364 & 288 & 261 & 327 & 309 & 342 & 37 \\
\hline $\mathrm{Ni}, \mathrm{ppm}$ & 900 & 918 & 886 & 799 & 819 & 915 & 857 & 868 & 38 \\
\hline$T,{ }^{\circ} \mathrm{C}$ & 1305 & 1303 & 1293 & 1265 & 1264 & 1303 & 1285 & 1283 & 15 \\
\hline $\log f_{\mathrm{O}_{2}}$ & -9.0 & -9.0 & -9.1 & -9.4 & -9.4 & -9.0 & -9.2 & -9.2 & 0.2 \\
\hline dNNO & -2.5 & -2.5 & -2.5 & -2.5 & -2.5 & -2.5 & -2.5 & -2.5 & 0 \\
\hline Fo, mol \% & 87 & 87 & 86.5 & 85 & 85 & 87 & 86 & 86.0 & 0.8 \\
\hline $\mathrm{NiO}_{O l}$ & 0.81 & 0.82 & 0.84 & 0.85 & 0.89 & 0.83 & 0.84 & 0.85 & 0.03 \\
\hline$O l, \%$ & 14.9 & 15.1 & 13.9 & 13.7 & 13.2 & 15.2 & 14.4 & 14.4 & 0.6 \\
\hline
\end{tabular}

Note: $T,{ }^{\circ} \mathrm{C}$ and $\log f_{\mathrm{O}_{2}}$ are the equilibrium temperature and oxygen fugacity, respectively; dNNO is the deviation of the logarithm of oxygen fugacity from the $\mathrm{Ni}-\mathrm{NiO}$ buffer; $\mathrm{Fo}$ and $\mathrm{NiO}_{\mathrm{Ol}}(\mathrm{wt} \%$ are the compositional characteristics of equilibrium olivine; $\mathrm{Ol}, \%$ is the amount of added olivine, wt \%; and values in bold show the arithmetic mean composition of primary melts and the standard deviation of the mean. 

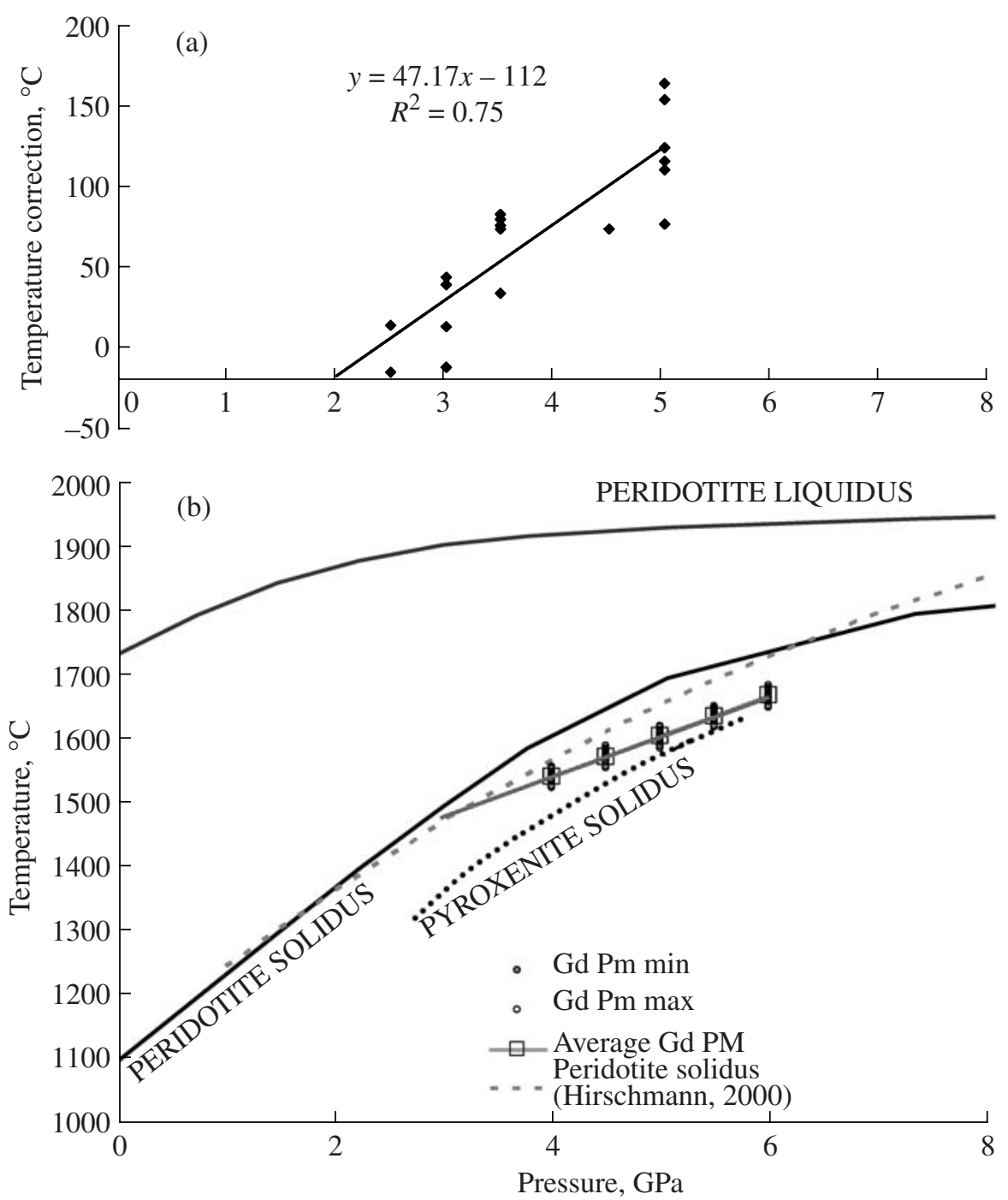

Fig. 12. Estimation of the $P-T$ conditions of formation of the primary magmas of the Gudchikhinsky Formation.

(a) Difference of the calculated and experimental temperatures of melt-high-calcium pyroxene equilibrium for experiments on pyroxenite melting (Kogiso et al., 2003; Tuff et al., 2005; Yaxley and Sobolev, 2007; Sobolev et al., 2007). Also shown is the equation of linear regression with the coefficient of linear correlation $R$.

(b) Results of estimation of the liquidus temperature of the primary melt of the Gudchikhinsky Formation.

The solid lines indicate the liquidus and solidus of primitive peridotite after McKenzie and Bickle (1988), the short-dashed line is the solidus of primitive peridotite after Hirschmann (2000), and the dotted line is the solidus of pyroxenite extrapolated on the basis of the data of Sobolev et al. (2007). Gd PM max and Gd PM min are the calculated liquidus of the primary melts of the Gudchikhinsky Formation corresponding to the upper and lower boundaries of the compositional field of melts derived from pyroxenite (Fig. 11), respectively. The temperatures were calculated using the model of Danyushevsky et al. (1996) taking into account the correction based on the equation presented in Fig. 12a. The Average Gd PM is the liquidus of the arithmetic mean composition of all calculated primary melts of the Gudchikhinsky Formation.

$1550^{\circ} \mathrm{C}$ arrive below lithospheric block of different age and different thickness: an ancient and thick continental lithosphere $(130 \mathrm{~km})$ similar to that of the Siberian craton (Fig. 14b) and a younger and thinner oceanic lithosphere $(90-100 \mathrm{~km})$ exemplified by the Hawaiian Islands (Fig. 14c). The ascending flow of mantle material is blocked by the lithosphere, and, consequently, the minimum pressure of decompression mantle melting is constrained by the lithosphere thickness. Let us assume that the two mantle plumes contain identical amounts of recycled material represented by eclogite. Such an assumption is reasonable, because the buoyancy of mantle material with heavy eclogite is directly dependent on its temperature, i.e., the potential temperature of the mantle plume (Pertermann and Hirschmann, 2003). Modeling showed that recycled crustal material (eclogite) will melt at depths of 170$150 \mathrm{~km}$ producing an andesitic melt, which will react with peridotite to form reaction pyroxenite (Sobolev et al., 2005). The melting of eclogite must produce a 


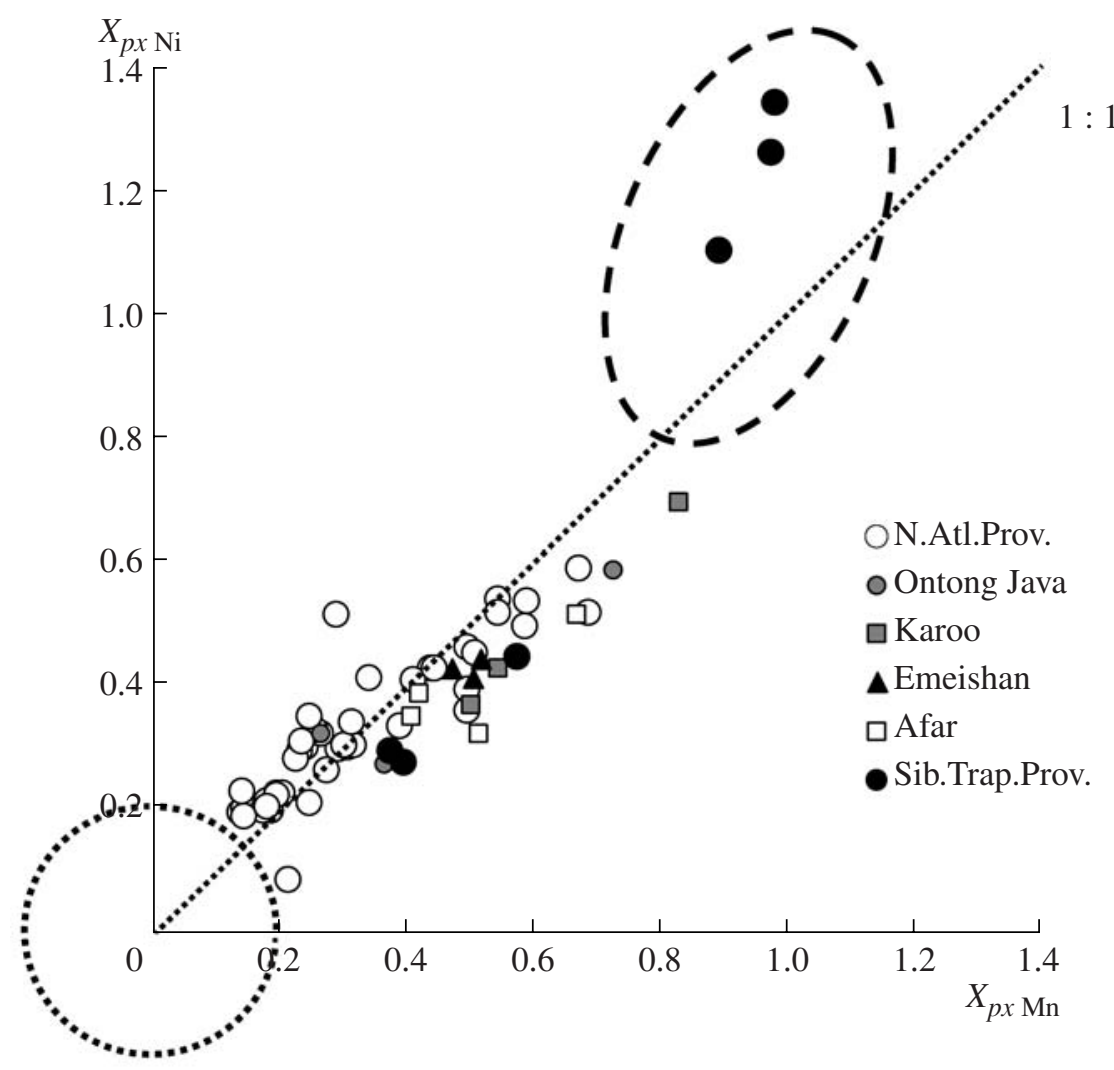

Fig. 13. Fractions of melts derived from the pyroxenite component $\left(X_{p x}\right)$ in the magmas of LIP calculated from the composition of olivine phenocrysts (Sobolev et al., 2007).

$X_{p x \mathrm{Mn}}$ and $X_{p x \mathrm{Ni}}$ are the linear functions of the $\mathrm{Mn} / \mathrm{Fe}$ and $\mathrm{NiO} /(\mathrm{MgO} / \mathrm{FeO})$ ratios in olivine (Sobolev et al., 2008). The fields correspond to the compositions of olivine equilibrated at low pressures with the products of melting of peridotites (dotted line) and pyroxenite (dashed line) after Sobolev et al. (2007). N.Atl.Prov. is the North Atlantic Province and Sib.Trap.Prov is the Siberian trap province.

refractory residue enriched in magnesian garnet, which does not participate in further melting processes. At depths of $150-120 \mathrm{~km}$, the reaction pyroxenite will melt, and peridotite will be involved in the melting reaction starting from depths of $100 \mathrm{~km}$ and less. It is evident that, in the case of a thick continental lithosphere, mantle plume magmatism will be almost exclusively controlled by the melting of reaction pyroxenite, a derivative of recycled crustal material (Fig. 14b). In the case of a thinner lithosphere, both pyroxenite and peridotite materials will be affected by melting (Fig. 14c). The contribution of peridotite will increase with a decrease in the lithosphere thickness, other conditions being equal.

This simple model adequately explains the difference between the magmatic products of the Hawaiian mantle plume and the initial stage of the development of the Siberian trap province. The idea of this model was first advanced by Sobolev et al. (2005), and a similar hypothesis of ferropicrite formation in continental LIP was published by Tuff et al. (2005) already one month later.
The further evolution of Siberian trap magmatism included the involvement of considerable amounts of melts derived from mantle peridotite at pressures of less than $3 \mathrm{GPa}$ (Figs. 2, 14d). This process had to occur very rapidly, probably catastrophically, because a change in mantle source material is recorded in the products of crystallization of various magmas occurring above one another within a $150-\mathrm{m}$ interval of the stratigraphic sequence of lavas, which is less than $5 \%$ of the thickness of the whole tuff-lava section in the Noril'sk region (Fig. 2). Such a catastrophe could be caused by the delamination and collapse of part of the continental lithosphere (Elkins-Tainton, 2005). This process could be triggered by the emplacement of the Gudchikhinsky magmas, which produced eclogitic intrusions in the continental lithosphere at depths of more than $60 \mathrm{~km}$. Owing to the emplacement of such bodies, the lithosphere became hotter and heavier, and its gravitational destabilization and collapse could occur within a short time interval (Elkins-Tainton and Hager, 2000). This implies that the parental melt of the province could be much more voluminous than the observed amount of lavas in the Gudchikhinsky Forma- 

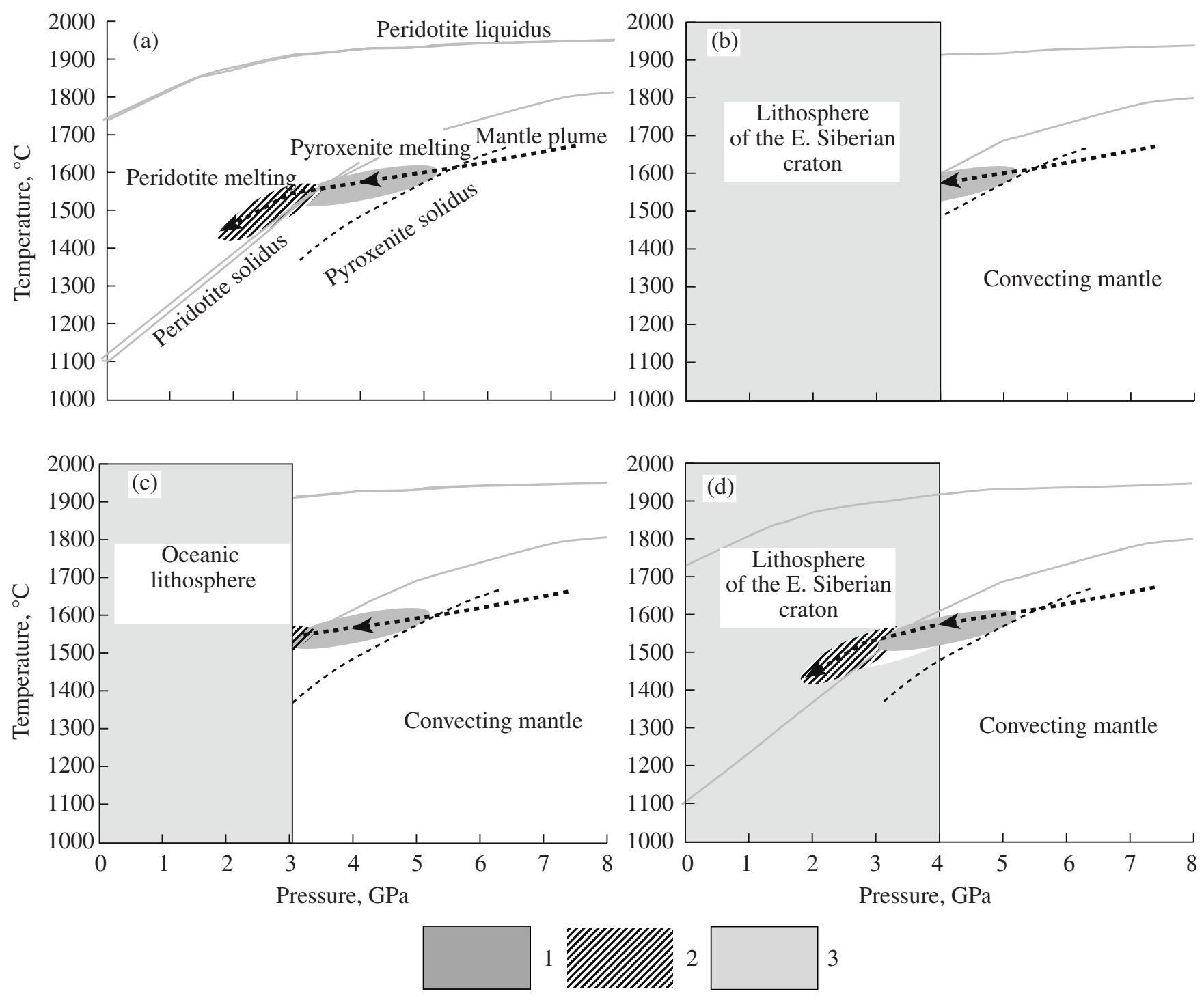

Fig. 14. Schematic model of magma formation in a mantle plume beneath the lithosphere of different thickness.

The liquidus and solidus of peridotite and the solidus of pyroxenite are given after Fig. 12b. Fields: (1) melting range of pyroxenite (according to Fig. 12b), (2) melting of peridotite, and (3) lithosphere of varying thickness.

tion (almost $15000 \mathrm{~km}^{3}$; Fedorenko et al., 1996) at the expense of the products of their deep crystallization.

The total contribution of pyroxenite-derived melts into the magmatism of the Siberian trap province can be estimated as 40-50 wt \% from the presented data and assuming that the parental melts of the Tuklonsky picrites studied by us belonged to the main low-Ti type of Siberian trap magmas.

The mechanism of the initiation of the delamination and collapse of the continental lithosphere proposed previously by Elkin-Tanton and Hager (2000) could not adequately explain the formation of huge magma volumes beneath the thick continental lithosphere. Proceeding from the compositions of olivine and parental melt of the Gudchikhinsky picrites, we propose in this paper such an explanation based on the preferential melting of low-melting point mantle heterogeneities (pyroxenites).

\section{Pyroxenite Source and the Ore Potential of the Siberian Traps}

We showed above how the investigation of melt inclusions in olivine from the least contaminated rocks allowed us to determine the composition of primary magmas for the early stage of the development of the Siberian traps. These melts corresponded to tholeiitic picrites, were strongly S-undersaturated (Fig. 10), and showed high $\mathrm{Ni}$ and $\mathrm{Cu}$ contents (Fig. 15). These features were related to the peculiar composition of the source of these magmas, an olivine-free pyroxenite produced by the reaction between the recycled oceanic 
crust and mantle peridotite. Since such a pyroxenite is inherently depleted in sulfur and can easily reach high degrees of melting (Sobolev et al., 2007), leaving a residue free of sulfide melt, olivine, and spinel, the resulting melt must be enriched in chalcophile and siderophile elements and depleted in sulfur (Sobolev et al., 2008). Hence, the presence of pyroxenite in the source region of Siberian traps could play a key role in the generation of high contents of $\mathrm{Ni}, \mathrm{Cu}$, and Pt-group elements and low sulfur content in the parental magmas. Furthermore, the strong undersaturation of the trap magmas with respect to sulfur prevented the early dispersion of these elements through the fractionation of sulfide melt. In particular, it can be clearly seen in Fig. 15 that $\mathrm{Cu}$ shows incompatible behavior in the Gudchikhinsky melts and is accumulated with decreasing $\mathrm{Mg}$ content, in contrast to mid-ocean ridge basalts, in which $\mathrm{Cu}$ is buffered by sulfide melt. The behavior of platinum-group elements must be identical to that of copper because of their pronounced chalcophile character. The source of sulfur in the sulfide ores was evidently the continental crust and the sulfur of the magmas accumulated during their extensive fractionation (Naldrett et al., 1992). Thus, the pyroxenite source of the Siberian trap magmas was probably an essential prerequisite for the formation of unique commercial nickel sulfide deposits of the Noril'sk region.

\section{On the Role of Siberian Traps in the Mass Extinction at the Paleozoic-Mesozoic Boundary}

Within the accuracy of numerous age determinations, the formation of the province coincided with the largest mass extinction at $251 \mathrm{Ma}$ at the PaleozoicMesozoic boundary and is therefore considered as a possible main reason for this catastrophe (Campbell et al., 1992; Kamo et al., 2003; White and Saunders, 2005). The emission of greenhouse gases $\left(\mathrm{CO}_{2}, \mathrm{H}_{2} \mathrm{~S}\right.$, $\mathrm{SO}_{2}$, and $\mathrm{Cl}$ compounds) into the atmosphere is believed to be the main mechanism. Our results provide the first estimates of the contents of volatile components in the primary magmas from a pyroxenite source, which probably produced approximately half of the magma volume of the province (see the Composition of Mantle Source section).

Compared with other melts of similar $\mathrm{Mg}$ content, the reconstructed magmas show rather low $\mathrm{H}_{2} \mathrm{O}, \mathrm{CO}_{2}$, and $\mathrm{S}$ contents and, by themselves, could hardly release considerable amounts of these gases, except, probably, for $\mathrm{CO}_{2}$ (Ryabchikov et al., 2004). However, the initial trap magmas are significantly enriched in $\mathrm{Cl}$ compared with typical mantle melts (Fig. 10). Moreover, the $\mathrm{Cl}$ content increases considerably during magma evolution, owing probably to interaction with evaporites. Beerling et al. (2007) modeled the effect of the Siberian trap magmatism on the environment and showed that the combined influence of $\mathrm{HCl}$ degassing from the magmas and gas release due to heating of sedimentary coals could results in a $75-80 \%$ destruction of the

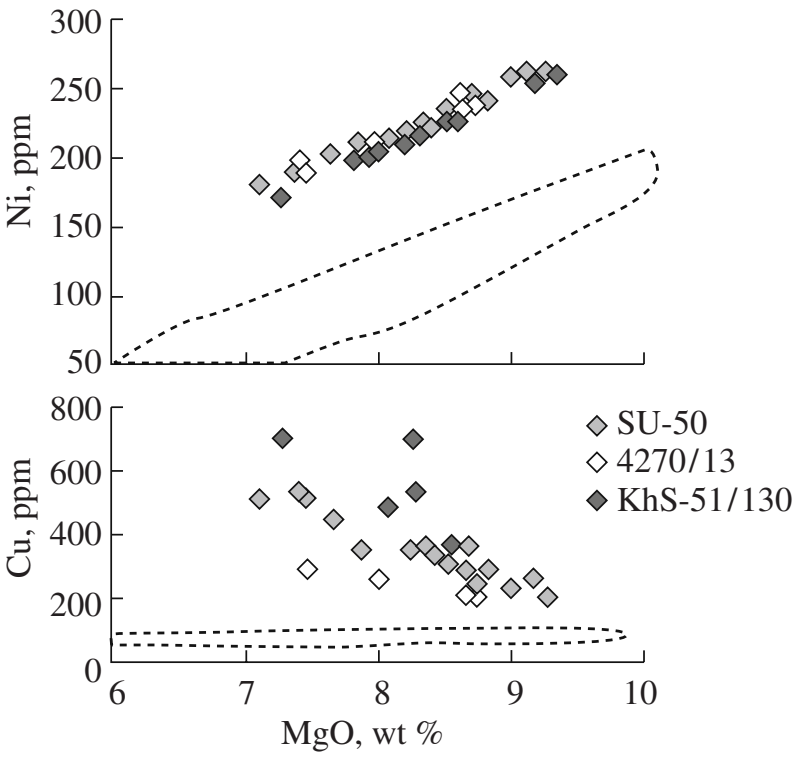

Fig. 15. Contents of ore elements in melts trapped in olivine phenocrysts from the Gudchikhinsky picrites.

All compositions were recalculated to equilibrium with the host olivine (see text for explanation). The dotted contour shows the compositional field of glasses from mid-ocean ridge basalts according to the PetDB database (http://www. petdb.org/petdbWeb/index.jsp).

stratospheric ozone layer and lethal mutations of vegetation promoted by ultraviolet radiation. These calculations used an estimate of $2.2 \times 10^{6} \mathrm{Tg}$ for the bulk $\mathrm{HCl}$ degassing of Siberian traps, which is based on the volume of the trap magmas $\left(4 \times 10^{6} \mathrm{~km}^{3}\right)$ and $\mathrm{Cl}$ contents in the basalts of the Columbia River province in the United States. For the same magma volume, the minimum estimate of $2.3 \times 10^{6} \mathrm{Tg}$ can be obtained for the $\mathrm{HCl}$ emission on the basis of $\mathrm{Cl}$ contents in the primary Gudchikhinsky magmas (310 ppm, Table 6) and in peridotite-derived magmas (100 ppm, Saal et al., 2002). Taking into account the accumulation of $\mathrm{Cl}$ in melt during phenocryst crystallization, the real magnitude of emission will be significantly higher, $3.8 \times 10^{6} \mathrm{Tg}$, assuming that the average Siberian trap basalt underwent $40 \%$ crystallization. For the contaminated melts of sample SU-50 (Fig. 10, Table 4), this estimate is several times higher. Consequently, the results of our study indicate that the real $\mathrm{HCl}$ emission from the Siberian traps could be significantly higher than that used in the model of Beerling et al. (2007), and the environmental impact of this process was, correspondingly, more dramatic than was previously thought.

Thus, the high initial $\mathrm{Cl}$ contents in the magmas and their interaction with the continental crust and, especially, with its sedimentary part with abundant evaporite deposits could lead to considerable $\mathrm{HCl}$ emission and a catastrophic impact on the environment. 


\section{CONCLUSIONS}

(1) Based on the investigation of olivine phenocrysts and melt and spinel inclusions in them from the picrites of the Gudchikhinsky Formation and olivine phenocrysts and whole-rock geochemistry from the Tuklonsky and Nadezhdinsky formations of the Noril'sk region, we determined the composition and conditions of formation and evolution of the parental melts and mantle sources of Siberian trap magmatism.

(2) In all of the samples, olivine phenocrysts show $\mathrm{Ni}$ excess and Mn deficit compared with the olivine equilibrated with melts produced by peridotite partial melting, which indicates a significant role of a nonperidotitic material (olivine-free pyroxenite) in their mantle source. Based on the composition of olivine, it was shown that the beginning of the magmatism of the province (Gudchikhinsky Formation) was related to the melting of only a pyroxenite source $(100 \mathrm{wt} \%)$ produced by the interaction of the ancient recycled oceanic crust with mantle peridotite. During the further evolution of the magmatic system (Tuklonsky and Nadezhdinsky formations), the contribution of the pyroxenite component in the source decreased rapidly (to 40 and 60 wt \%, respectively) owing to the involvement of peridotite material in melting. The formation of magmas was accompanied by their considerable crustal contamination. The total contribution of pyroxenite melting products to the magmatism of the Siberian trap province can be estimated as 40-50 wt \% .

(3) The investigation of melt and spinel inclusions in olivine demonstrated that the primitive magmas of the Gudchikhinsky Formation crystallized under near-surface conditions at temperatures of $1270-1170^{\circ} \mathrm{C}$ and oxygen fugacity $2.5-3.0$ orders of magnitude below the $\mathrm{Ni}-\mathrm{NiO}$ buffer. Their crystallization was accompanied by magma contamination with silicic continental rocks and evaporites.

(4) The least contaminated parental melts of the Gudchikhinsky rocks corresponded to tholeiitic picrites with 11-14 wt \% /MgO, were strongly undersaturated with respect to sulfur, showed low $(<0.25 \mathrm{wt} \%)$ contents of water and carbon dioxide and high $\mathrm{Cl}$ contents (>300 ppm), and were similar in composition to the Hawaiian tholeiites. They were produced by melting of a pyroxenite source at depths of $130-180 \mathrm{~km}$ in a mantle plume with a potential temperature of 1500$1580^{\circ} \mathrm{C}$.

(5) Owing to its low melting temperature, the presence of the pyroxenite component in the magma source of the Siberian traps resulted in the formation of large melt volumes beneath the thick continental lithosphere, which could trigger its catastrophic collapse. The same component, whose residue was devoid of sulfides and olivine, played a key role in the generation of high contents of $\mathrm{Ni}, \mathrm{Cu}$, and platinum-group elements and low contents of sulfur in parental trap magmas and prevented the early dispersion of these elements by sulfide melt fractionation.
(6) The high initial contents of $\mathrm{Cl}$ in the magmas and melt contamination by evaporites could be responsible for the considerable emission of $\mathrm{HCl}$ to the atmosphere resulting in mass extinction at the Paleozoic-Mesozoic boundary.

\section{ACKNOWLEDGMENTS}

The authors thank K.-P. Jochum and B. Stoll (MaxPlanck Institute of Chemistry, Mainz, Germany) for help in the analysis of inclusions by laser ablationinductively coupled plasma mass spectrometry; G. Brey (J.-W. Goethe University, Frankfurt am Maine, Germany) for the opportunity to perform experiments in a vertical quench furnace with controlled oxygen fugacity; O.B. Kuz'mina (Max-Planck Institute of Chemistry, Mainz, Germany) for assistance in sample preparation; I.A. Roshchina, T.V. Romashova (Vernadsky Institute of Geochemistry and Analytical Chemistry, Russian Academy of Sciences, Moscow), and D.Z. Zhuravlev (Institute of Mineralogy and Geochemistry of Rare Elements, Moscow) for the analysis of rocks; and V.B. Naumov (Vernadsky Institute of Geochemistry and Analytical Chemistry, Russian Academy of Sciences, Moscow) for constructive comments.

This study was financially supported by Program No. 4 of the Department of Earth Sciences of the Russian Academy of Sciences; Russian Foundation for Basic Research, project nos. 06-05-65234 and 07-0501007; and Russian President's Program for the Support of Leading Scientific Schools of Russia (NSh150.2008.5).

\section{REFERENCES}

1. I. M. Artemieva, and W.D. Mooney, "Thermal Thickness and Evolution of Precambrian Lithosphere: A Global Study," J. Geophys. Res. 106, 16387-16414 (2001).

2. P. Beattie, "Olivine-Melt and Orthopyroxene-Melt Equilibria," Contrib. Mineral. Petrol. 115, 103-111 (1993).

3. D. J. Beerling, M. Harfoot, A. Lomax, and J. A. Pyle, "The Stability of the Stratospheric Ozone Layer during the End-Permian Eruption of the Siberian Traps," Phil. Trans. R. Soc. London Ser. A. 365, 1843-1866 (2007).

4. I. H. Campbell and R. W. Griffiths, "The Changing Nature of Mantle Hotspots through Time-Implications for the Chemical Evolution of the Mantle," J. Geol. 100, 497-523 (1992).

5. L. A. Campbell, G. K. Czamanske, V. A. Fedorenko, et al., "Synchronism of the Siberian Traps and the Permian-Triassic Boundary," Science 258, 1760-1763 (1992).

6. D. Canil, "Vanadium in Peridotites, Mantle Redox and Tectonic Environments: Archean to Present," Earth Planet. Sci. Lett. 195, 75-90 (2002).

7. L. V. Danyushevsky, "The Effect of Small Amounts of $\mathrm{H}_{2} \mathrm{O}$ Crystallisation of Mid-Ocean Ridge and Backarc 
Basin Magmas," J. Volcanol. Geotherm. Res. 110, 265280 (2001).

8. L. V. Danyushevsky, A. V. Sobolev, and L. V. Dmitriev, "Estimation of the Pressure of Crystallization and $\mathrm{H}_{2} \mathrm{O}$ Content of MORB and AABB Glasses: Calibration of an Empirical Technique," Mineral. Petrol. 57, 185-204 (1996).

9. J. E. Dixon, L. Leist, C. Langmuir, and J.-G.Schilling, "Recycled Dehydrated Lithosphere Observed in PlumeInfluenced Mid-Ocean-Ridge Basalt," Nature. 420, 385389 (2002).

10. N. L. Dobretsov, A. A. Kirdyashkin, A. G. Kirdyashkin, et al., "Modelling of Thermochemical Plumes and Implications for the Origin of the Siberian Traps," Lithos 100, 66-92 (2008).

11. D. A. Dodin, B. N. Batuev, G. A. Mitenkov, et al., Atlas of the Rocks and Ores of the Noril'sk Copper-Nickel Deposits (Nedra, Leningrad, 1971) [in Russian].

12. O. A. Dyuzhikov, V. V. Distler, B. M. Strunin, et al., Geology and Ore Potential of the Noril'sk District (Nedra, Moscow, 1988) [in Russian].

13. L. T. Elkins-Tanton, "Continental Magmatism Caused by Lithospheric Delamination," in Plates, Plumes and Paradigms, Ed. by G. R. Foulger, J. H. Natland, D. C. Presnall, and D.L. Anderson, Geol. Soc. Am. Spec. Paper 388, 449-461 (2005).

14. L. T. Elkins-Tanton and B. H. Hager, "Melt Intrusion as a Trigger for Lithospheric Foundering and Eruption of the Siberian Flood Basalts," Geophys. Res. Lett. 27, 3937-3940 (2000).

15. V. A. Fedorenko, P. C. Lightfoot, A. J. Naldrett, et al., "Petrogenesis of the Siberian Flood-Basalt Sequence at Noril'sk, North Central Siberia," Int. Geol. Rev. 38, 99135 (1996).

16. C. E. Ford, D. G. Russel, J. A. Craven, and M. R. Fisk, "Olivine-Liquid Equilibria: Temperature, Pressure and Composition Dependence of Crystal/Liquid Cation Partition Coefficients for $\mathrm{Mg}, \mathrm{Fe}_{2+}, \mathrm{Ca}$ and Mn," J. Petrol. 24, 256-265 (1983).

17. Geological Map of the Noril'sk District at a Scale of $1: 200000$, Ed. by M. L. Sherman (Roskomitet Geol. Ispol'z. Nedr, Moscow, 1991) [in Russian].

18. C. Herzberg and M. J. O'Hara, "Plume-Associated Ultramafic Magmas of Phanerozoic Age," J. Petrol. 43, 1857-1883 (2002).

19. M. M. Hirschmann, "Mantle Solidus: Experimental Constraints and the Effects of Peridotite Composition," Geochem. Geophys. Geosyst. 1. 2000GC000070 (2000).

20. A. W. Hofmann, "Chemical Differentiation of the Earth: the Relationship between Mantle, Continental Crust, and Oceanic Crust," Earth Planet. Sci. Lett. 90, 297-314 (1988).

21. A. W. Hofmann, "Sampling Mantle Heterogeneity through Oceanic Basalts: Isotopes and Trace Elements," in Treatise on Geochemistry. The Mantle and Core, Ed. by H. D. Holland and K. K. Turekian (Elsevier, Amsterdam, 2002), Vol. 2, pp. 61-101.

22. A. W. Hofmann and W. M. J. White, "Mantle Plumes from Ancient Oceanic Crust," Earth Planet. Sci. Lett. 57, 421-436 (1982).
23. E. J. Jarosevich, J. A. Nelen, and J. A. Norberg, "Reference Sample for Electron Microprobe," Geostand. Newslett. 4, 43-47 (1980).

24. K. P. Jochum, D. B. Dingwell, A. Rocholl, et al., "The Preparation and Preliminary Characterisation of Eight Geological MPI-DING Reference Glasses for In-Situ Microanalysis," Geostand. Newslett. 24, 87-133 (2000).

25. S. L. Kamo, G. K. Czamanske, Y. Amelin, et al., "Rapid Eruption of Siberian Flood-Volcanic Rocks and Evidence for Coincidence with the Permian-Triassic Boundary and Mass Extinction at $251 \mathrm{Ma}$," Earth Planet. Sci. Lett. 214, 75-91 (2003).

26. O. Kogiso, M. M. Hirschmann, and D. J. Frost, "HighPressure Partial Melting of Garnet Pyroxenite: Possible Mafic Lithologies in the Source of Ocean Island Basalts," Earth Planet. Sci. Lett. 216, 603-617 (2003).

27. N. A. Krivolutskaya, A. V. Sobolev, V. N. Mikhailov, and I. A. Roshchina, "New Data on the Formational Affiliation of Picritic Basalts of the Norilsk District," Dokl. Akad. Nauk 403, 67-81 (2005) [Dokl. Earth Sci. 402, 542-546 (2005)].

28. P. C. Lightfoot, C. J. Hawkesworth, J. Hergt, et al., "Remobilisation of the Continental Lithosphere by a Mantle Plume: Major-, Trace-Element, and Sr-, Nd-, and $\mathrm{Pb}-$ Isotopic Evidence from Picritic and Tholeiitic Lavas of the Noril'sk District, Siberian Trap, Russia," Contrib. Mineral. Petrol. 114, 171-188 (1993).

29. V. L. Masaitis, "Permian and Triassic Volcanism of Siberia: Problems of Dynamic Reconstructions," Zap. Vses. Mineral. O-va 112, 412-425 (1983).

30. E. A. Mathez, "Sulfur Solubility and Magmatic Sulfides in Submarine Basalt Glass," J. Geophys. Res. 81, 42694276 (1976).

31. C. Maurel and P. Maurel, "Etude experimentale de 1'equilibre $\mathrm{Fe}^{2+}-\mathrm{Fe}^{3+}$ dans les spinelles chromiferes et les liquides silicates basiques coexistants a $1 \mathrm{~atm}, "$ C.R. Acad. Sci. Paris. 285, 209-215 (1982).

32. D. McKenzie and M. J. Bickle, "The Volume and Composition of Melt Generated by Extension of the Lithosphere," J. Petrol. 29, 625-679 (1988).

33. A. J. Naldrett, P. C. Lightfoot, V. Fedorenko, et al. "Geology and Geochemistry of Intrusions and Flood Basalts of the Noril'sk Region, USSR, with Implications for the Origin of the Ni-Cu Ores," Econ. Geol. 87, 975-1004 (1992).

34. M. Pertermann and M. M. Hirschmann, "Partial Melting Experiments on a MORB-Like Pyroxenite between 2 and $3 \mathrm{GPa}$ : Constraints on the Presence of Pyroxenite in Basalt Source Regions from Solidus Location and Melting Rate," J. Geophys. Res. Solid Earth 108, 2125 (2003).

35. M. K. Reichow, A. D. Saunders, R. V. White, et al., "Geochemistry and Petrogenesis of Basalts from the West Siberian Basin: An Extension of the Siberian Traps, Russia," Lithos 79, 425-452 (2005).

36. E. Roedder, Fluid Inclusions Rev. Mineral. 14 (1984).

37. A. W. Rudnick, "Composition of the continental crust," in Treatise on Geochemistry. The Crust, Ed. by H. D. Holland and K. K. Turekian (Elsevier, Amsterdam, 2002), Vol. 3, pp. 1-64. 
38. I. D. Ryabchikov, "Mechanisms and Conditions of Magma Formation in Mantle Plumes," Petrologiya 11, 548-555 (2003) [Petrology 11, 496-503 (2003)].

39. I. D. Ryabchikov, L. N. Kogarko, and T. Ntaflos, "Juvenile Flow of Carbon Dioxide and Causes of Global Environmental Changes at the Permian-Triassic Boundary," Dokl. Akad. Nauk 399, 815-817 (2004) [Dokl. Earth Sci. 399A, 815-817 (2004)].

40. V. V. Ryabov, A. Ya. Shevko, and M. P. Gora, "Magmatic Rocks of the Noril'sk District," in Petrology of Traps (Nonparel, Novosibirsk, 2000), Vol. 1 [in Russian].

41. A. E. Saal, E. H. Hauri, C. H. Langmuir, and M. R. Perfit, "Vapour Undersaturation in Primitive Mid-Ocean Ridge Basalt and the Volatile Content of Earth's Upper Mantle," Nature 419, 451-455 (2002).

42. M. Sharma, "Siberian Traps," in Large Igneous Provinces: Continental, Oceanic, and Planetary Flood Volcanism, Ed. by J. J. Mahoney and M. F. Coffin, Am. Geopys. Union Monograph 100, 273-295 (1997).

43. A. V. Sobolev, "Melt Inclusions in Minerals as a Source of Principle Petrological Information," Petrologiya 4, 228-239 (1996) [Petrology 4, 209-220 (1996)].

44. A. V. Sobolev and L. V. Danyushevsky, "Petrology and Geochemistry of Boninites from the North Termination of the Tonga Trench: Constraints on the Generation Conditions of Primary High-Ca Boninite Magmas," J. Petrol. 35, 1183-1213 (1994).

45. A. V. Sobolev and A. B. Slutskii, "Composition and Crystallization Conditions of the Parental Melt of the Siberian Meymechites in Connection with the General Problem of Ultrabasic Magmas," Geol. Geofiz., No. 12, 97-110 (1984).

46. A. V. Sobolev, V. S. Kamenetsky, and N. N. Kononkova, "New Petrological Data on Siberian Meymechites," Geokhimiya, No. 8, 1084-1095 (1991).
47. A. V. Sobolev, A. W. Hofmann, S. V. Sobolev, and I. K. Nikogosian, "An Olivine-Free Mantle Source of Hawaiian Shield Basalts," Nature 434, 590-597 (2005).

48. A. V. Sobolev, A. W. Hofmann, D. V. Kuzmin, et al., "The Amount of Recycled Crust in Sources of MantleDerived Melts," Science 316, 412-417 (2007).

49. A.V. Sobolev, A. W. Hofmann, G. Brügmann, et al., "A Quantitative Link between Recycling and Osmium Isotopes," Science 321, 536 (2008).

50. V. S. Sobolev, Petrology of the Traps of the Siberian Platform, Tr. Vsesoyuz. Arkt. Inst. (GY Sevmorputi, Leningrad, 1936), Vol. 43 [in Russian].

51. J. Tuff, E. Takahashi, and S. A. Gibson, "Experimental Constraints on the Role of Garnet Pyroxenite in the Genesis of High-Fe Mantle Plume Derived Melts," J. Petrol. 46, 2023-2058 (2005).

52. R. S. White and D. McKenzie, "Mantle Plumes and Flood Basalts," J. Geophys. Res. Solid Earth. 100, 17543-17585 (1995).

53. R. V. White and A. D. Saunders, "Volcanism, Impact and Mass Extinctions: Incredible or Credible Coincidences," Lithos 79, 299-316 (2005).

54. J. L. Wooden, G. K. Czamanske, V. A. Fedorenko, et al., "Isotopic and Trace-Element Constraints on Mantle and Crustal Contributions to Siberian Continental Flood Basalts, Norilsk Area, Siberia," Geochim. Cosmochim. Acta 57, 3677-3704 (1993).

55. G. M. Yaxley and A. V. Sobolev, "High-Pressure Partial Melting of Gabbro and Its Role in the Hawaiian Magma Source," Contrib. Mineral. Petrol. 154, 371-383 (2007).

56. V. V. Zolotukhin, A. M. Vilenskii, and O. A. Dyuzhikov, Basalts of the Siberian Platform (Nauka, Novosibirsk, 1986) [in Russian]. 